UNIVERSIDADE DE SÃO PAULO

FACULDADE DE ECONOMIA, ADMINISTRAÇÃO E CONTABILIDADE DEPARTAMENTO DE ADMINISTRAÇÃO PROGRAMA DE PÓS-GRADUAÇÃO EM ADMINISTRAÇÃO

INDICADORES DOS NEGÓCIOS SOCIAIS NA ÁREA DA SAÚDE: ESTUDOS DE CASOS

Matheus Roquette Ferrato da Silva

Orientadora: Profa. Dra. Graziella Maria Comini

SÃO PAULO 
Prof. Dr. João Grandino Rodas Reitor da Universidade de São Paulo

Prof. Dr. Reinaldo Guerreiro

Diretor da Faculdade de Economia, Administração e Contabilidade

Prof. Dr. Adalberto Américo Fischmann

Chefe do Departamento de Administração

Prof. Dr. Lindolfo Galvão de Albuquerque Coordenador do Programa de Pós-Graduação em Administração 


\title{
INDICADORES DOS NEGÓCIOS SOCIAIS NA ÁREA DA SAÚDE:
}

ESTUDO DE CASOS

\author{
Dissertação apresentada ao Departamento de \\ Administração da Faculdade de Economia, \\ Administração e Contabilidade da \\ Universidade de São Paulo, para obtenção do \\ título de Mestre em Ciências.
}

Orientadora: Profa. Dra. Dra. Graziella Maria Comini

\section{Versão Corrigida}

(Versão Original disponível na Faculdade de Economia Administração e Contabilidade)

SÃO PAULO 


\section{FICHA CATALOGRÁFICA}

Elaborada pela Seção de Processamento Técnico do SBD/FEA/USP

Silva, Matheus Roquette Ferrato da

Indicadores dos negócios sociais na área da saúde: estu-

dos de casos / Matheus Roquette Ferrato da Silva. -- São Paulo, 2013. $109 \mathrm{p}$.

Dissertação (Mestrado) - Universidade de São Paulo, 2013.

Orientador: Graziella Maria Comini.

1. Empreendedorismo social 2. Negócio social 3. Mensuração de desempenho organizacional 4. Relações interorganizacionais 5. Saúde I. Universidade de São Paulo. Faculdade de Economia, Administração e Contabilidade. II. Título.

CDD -361.2 
Aos meus queridos pais. 


\section{AGRADECIMENTOS}

Agradeço a todos que contribuíram com este trabalho, direta e indiretamente. Agradeço muito à minha querida orientadora Graziella que foi uma pessoa fundamental para que eu chegasse ao fim deste valioso ciclo em minha vida. Este trabalho não teria sido realizado sem a ajuda de meu grande amigo Renato, que muito além de abrir portas e conexões, foi sempre uma pessoa disposta a ensinar, motivar e inspirar. Agradeço a toda equipe da Artemisia que me colocou neste caminho sem volta dos negócios sociais.

Agradeço pelo tempo, atenção e por conduzirem tão bem seus negócios por este difícil caminho dos negócios sociais: Gilberto da Vox Capital, Edgard do Saútil, Dr. Roberto e Juliana do Projeto CIES, Rubens e Zumira da Sorridents e Tessiana da Clínica SiM.

Agradeço a todos aqueles que me apoiaram nos momentos de desespero, meus amigos da FEA (Bassiro, Gabriela, Talita, Tobias e muitos outros), à Márcia por me receber tão bem em sua sala e por me salvar de alguns percalços e aos funcionários da FEA, que sempre estavam dispostos a ajudar. Agradeço aos grandes professores que tive durante este período, que serviram como inspiração e são referências de profissionais importantes para minha vida e para minha formação intelectual.

Agradeço aos meus amigos, à minha família e à minha companheira Juliana que sempre me deram força, me incentivaram e que são minha estrutura elementar. 


\section{RESUMO}

A questão da saúde é um problema central e ganha destaque na inédita onda de protestos ocorridos em 2013 no país. Isso é ocasionado pelas deficiências de atendimento do Sistema Único de Saúde, utilizado por cerca de $80 \%$ dos brasileiros, e pela regulação para soluções privadas. Entretanto, há iniciativas, chamadas de negócios sociais, que utilizam mecanismos de mercado para que as pessoas tenham acesso a medicamentos, tratamentos médicos e odontológicos. Esses empreendimentos atuam na busca por bons resultados financeiros e pelo atendimento de alta qualidade à população carente. Entretanto, os objetivos não são alcançados facilmente, principalmente pela necessidade de monitorar a geração de valor social. Este estudo tem o objetivo de identificar como os negócios sociais na área da saúde lidam com as métricas, principalmente em relação ao impacto social. Foram entrevistados quatro negócios sociais e duas organizações de apoio para entender como essa questão foi abordada e quais foram as principais barreiras. Foi constatado que pouco é feito na análise de impacto, uma vez que o foco das empresas está voltado para a sustentabilidade financeira. Por meio da pesquisa, fica clara a importância da interação com os atores do ecossistema, que contribuem na superação de barreiras e dificuldades na gestão de métricas e, assim, melhoram a avaliação de indicadores. Pelo estágio da gestão de indicadores e pela formação recente desse ecossistema, ainda é precipitado dizer quais serão as consequências da falta de atenção a essas métricas, além de precisar sobre como torná-las ferramentas efetivas de decisões estratégicas - ponto que deverá ser aprofundado em futuras pesquisas. 


\begin{abstract}
The health issue is a central problem and gain prominence in the unprecedent wave of 2013 protests around the country. This is caused by deficiencies in the Public Health Care System, used by about $80 \%$ of all Brazilians, and by the regulation for private solutions. However, there are initiatives, called social enterprises, which use market tools for people to have access to medicines, medical and dental care. These actions seek good financial results and provide high-quality care to the poor population. The goals are not easily achieved mainly by careful measurement and generation of social value. This study aims to identify how social businesses in healthcare deal with the metrics especially in related to social impact. Four social businesses and two social support organizations representatives were interviewed to understand how these issues were addressed and what the main barriers were. It was noted that little has been done on the impact analysis, since the focus of the companies is facing the financial sustainability. Through research, the interaction with the ecosystem performers is clearly important, contributing to overcoming barriers and difficulties in managing metrics and thus might improve the indicator evaluation. According to the pace of management indicators and the recent formation of this ecosystem it is still too early to say what could be the consequences of the lack of attention to these metrics, also about how to turn them into effective tools for strategic decisions. This topic should be better explored in future research.
\end{abstract}




\section{SUMÁRIO}

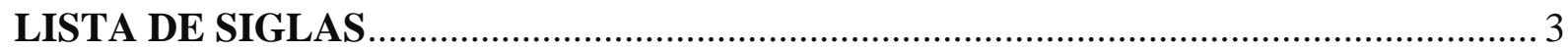

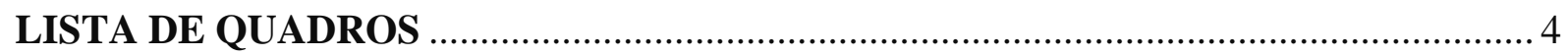

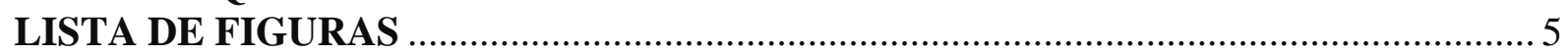

1 INTRODUÇÃ

2 DEBATE SOBRE NEGÓCIOS SOCIAIS............................................................... 11

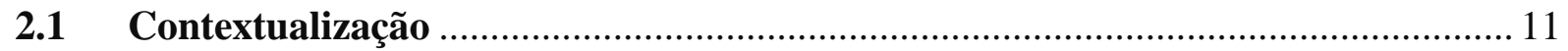

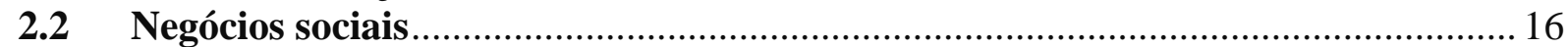

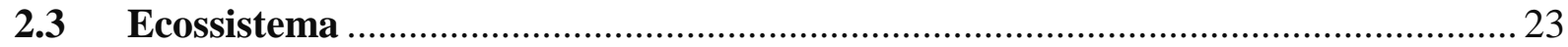

2.3.1 Ecossistemas de negócios ...................................................................................22

2.3.2 Papel dos atores ........................................................................................ 24

2.3.3 Ecossistema de negócios sociais.............................................................................. 27

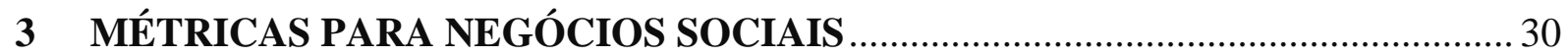

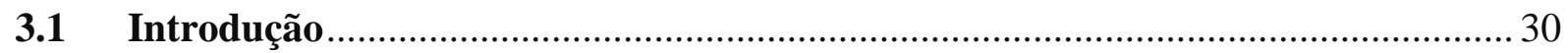

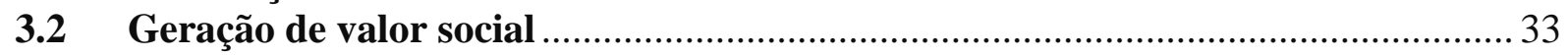

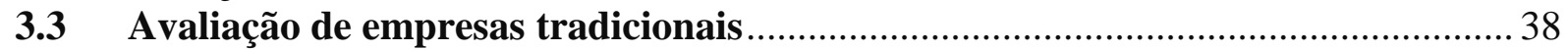

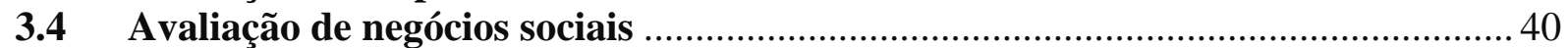

3.5 Diferentes óticas para a avaliação de valor social ………………………………. 44

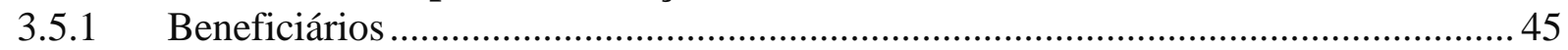

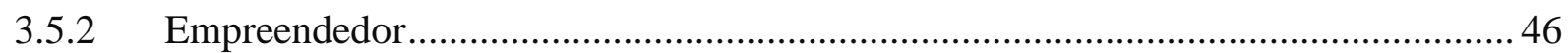

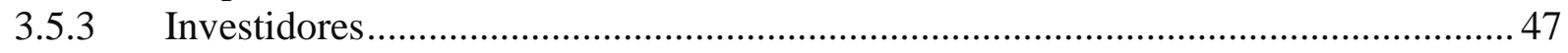

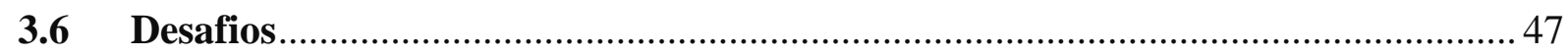

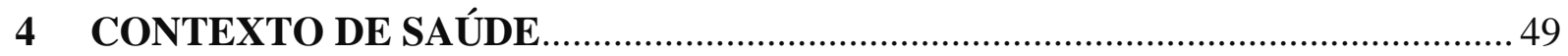

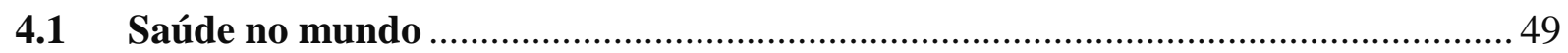

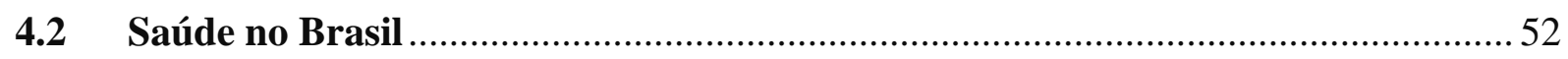

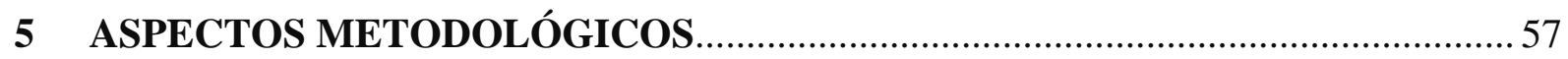

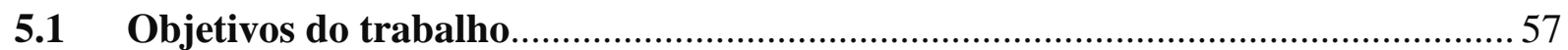

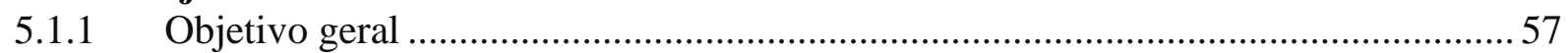

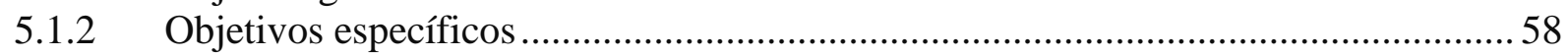

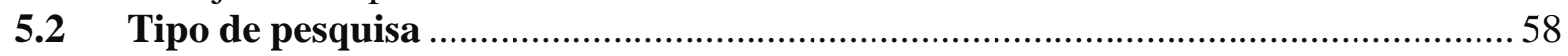

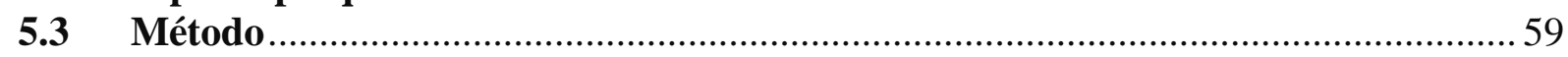

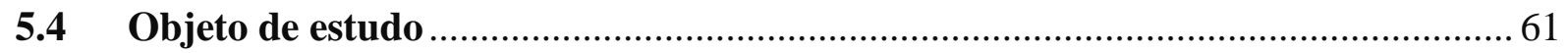

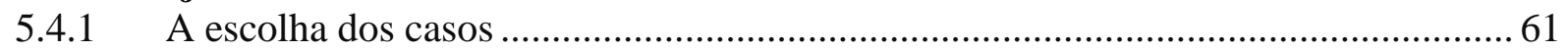

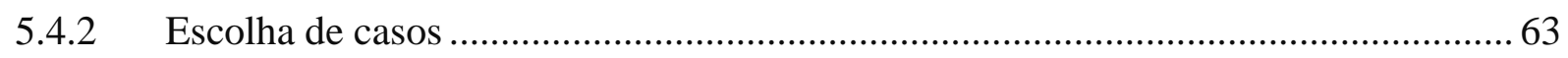

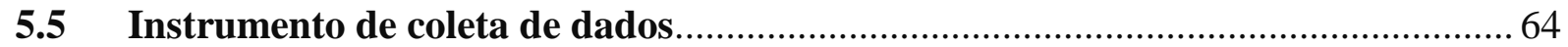

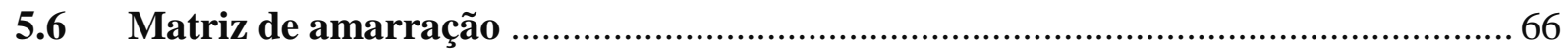

6 APRESENTAÇÃO DOS CASOS E RESULTADOS ………………………….......... 69

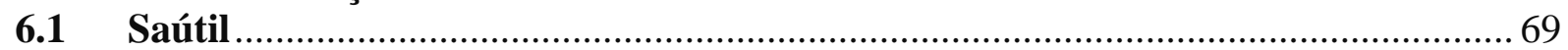

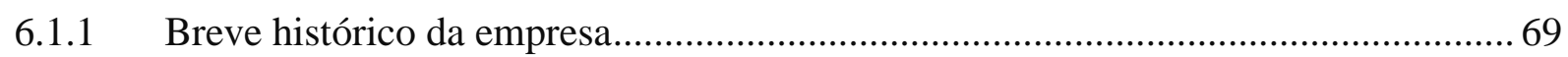

6.1.2 Geração de valor social...................................................................................... 70

6.1.3 Modelo de negócio da empresa ...................................................................... 70

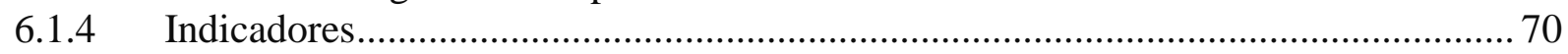




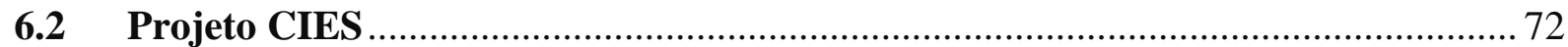

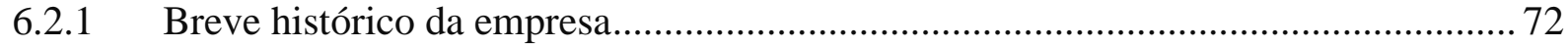

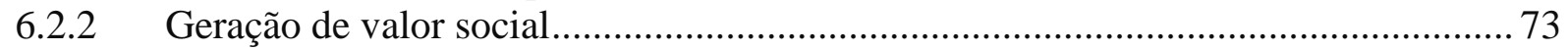

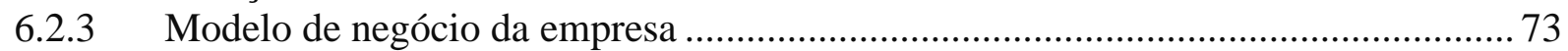

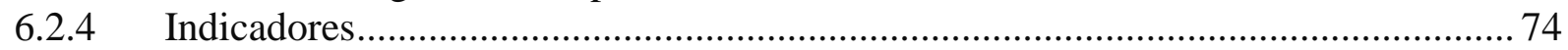

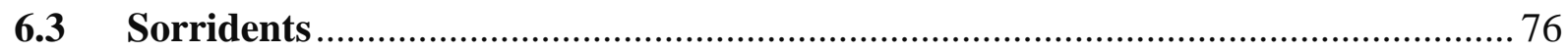

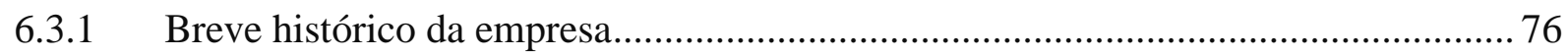

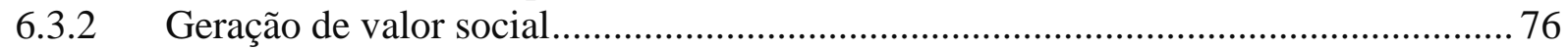

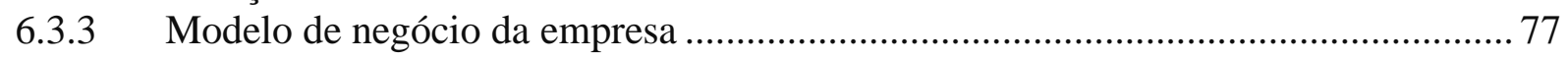

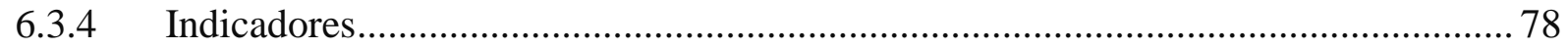

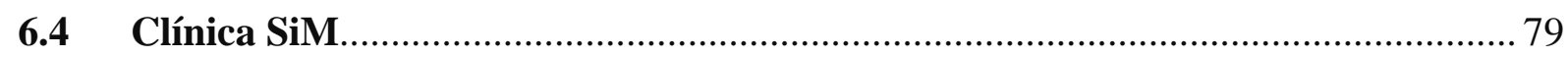

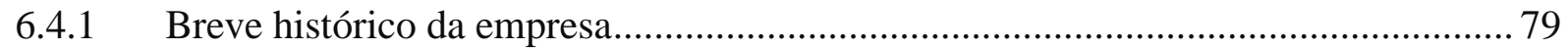

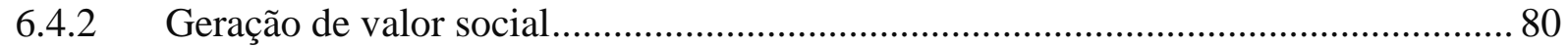

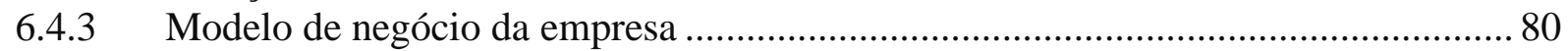

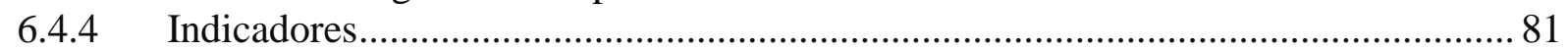

6.5 Discussão sobre os resultados e análise comparativa dos casos ............................ 82

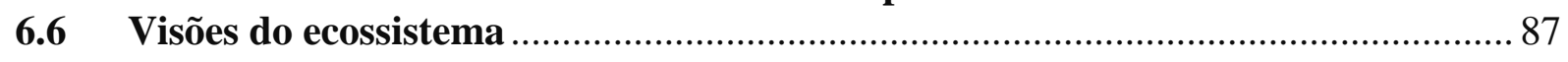

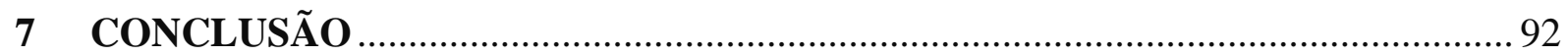

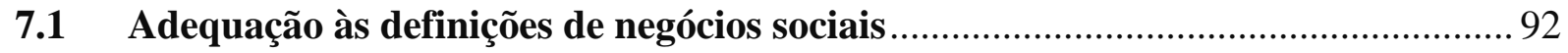

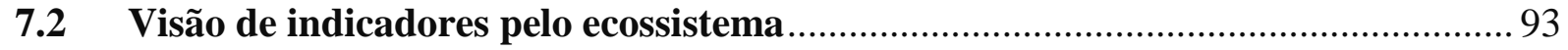

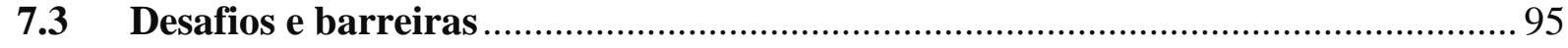

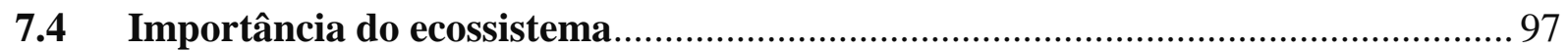

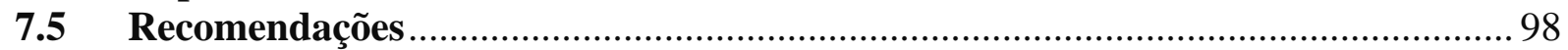

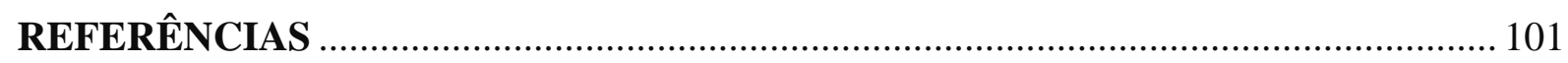

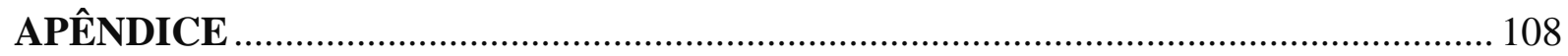


LISTA DE SIGLAS

CIES: Centro de Integração de Educação e Saúde DNA: Ácido Desoxirribonucleico

EUA: Estados Unidos da América

GIIRS: Global Impact Investing Ratings System

IRIS: Impact Reporting and Investment Standards

L3C: Low-Profit Limited Liability Company

ONGs: Organizações Não Governamentais

PIB: Produto Interno Bruto

SEKN: Social Enterprise Knowledge Network

SROI: Social Return on Investment

SUS: Sistema Único de Saúde 


\section{LISTA DE QUADROS}

Quadro 1 - Quadro comparativo entre as abordagens regionais na definição de Negócios Sociais

Quadro 2 - Papel econômico dos agentes no Vale do Silício................................................25

Quadro 3 - Principais elementos de geração de valor social ................................................ 36

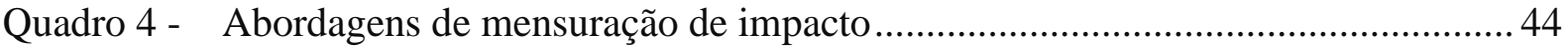

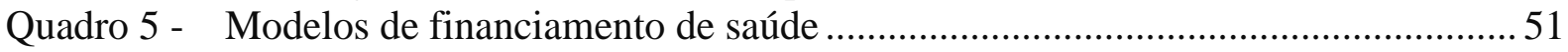

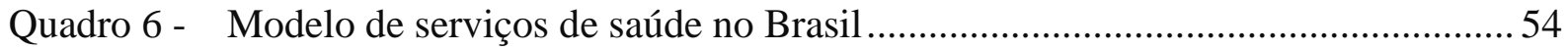

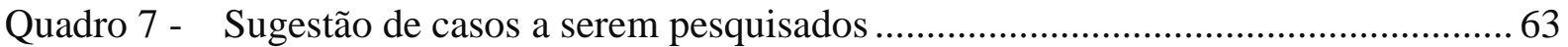

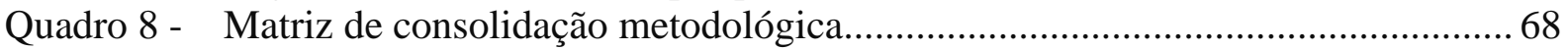

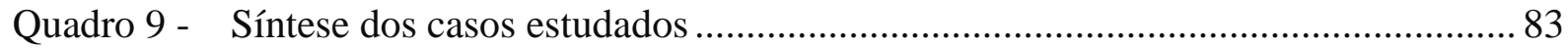

Quadro 10 - Síntese dos indicadores de gestão de valor social............................................. 85 


\section{LISTA DE FIGURAS}

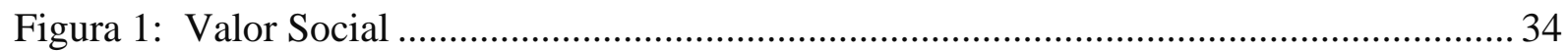

Figura 2: Três dimensões a considerar na aproximação à cobertura universal ....................... 50

Figura 3: Parâmetros de avaliação de implantação e uso de métricas ...................................... 66

Figura 4: Distribuição dos negócios estudados em relação aos eixos dos Negócios

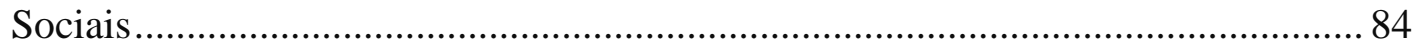

Figura 5: Visão dos casos em relação ao acompanhamento de indicadores sociais e

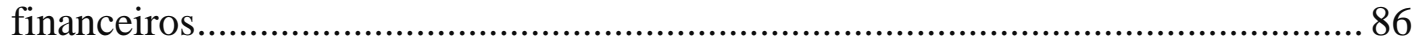




\section{INTRODUÇÃO}

O desenvolvimento tecnológico e científico cresce em velocidade exponencial. As evoluções se mostram cada vez mais rápidas e capazes de gerar soluções para muitos tipos de problemas, inclusive os mais complexos; por exemplo, a manipulação de ácido desoxirribonucleico - DNA - que, utilizando ferramentas simples como se fossem uma linguagem de programação, constrói robôs confiáveis de baixo custo para tarefas a serem programadas ou mesmo impressoras 3D de órgãos humanos.

Os avanços tecnológicos, no entanto, ainda não foram capazes de gerar soluções para problemas como: conflitos políticos, religiosos, étnicos e ideológicos, que apresentam consequências graves, a exemplo das centenas de mortes que ocorrem constantemente em virtude desses embates. Estes podem parecer pontuais e talvez representem situações mais agudas, sendo que existem problemas crônicos que afetam ainda grande parte da população. Esses problemas são geralmente questões sociais, como má distribuição de renda, problemas de moradia, deficiência no acesso à educação, saúde, alimentação, crédito e produtos essenciais, além de problemas de exclusão do mercado de trabalho.

Por se tratar de problemas tão recorrentes e presentes há bastante tempo, muitas das entidades supranacionais - assim como organizações da sociedade civil, instituições governamentais e até empresas privadas - começam a criar formas de minimizar esses problemas, principalmente a partir da década de 1990. No entanto, os resultados ainda não foram suficientes para resolver questões essenciais com atuações isoladas. Na tentativa de construir novas formas de atuação, foram constituídas parcerias entre ONGs, Organizações Não Governamentais, e empresas privadas. Essas parcerias visavam canalizar recursos das empresas direcionados para atividades de responsabilidade social e a experiência em gestão das mesmas com o conhecimento profundo das necessidades deste público e com competências de lidar com situações de vulnerabilidade sociais, apresentadas pelas organizações do terceiro setor (FISCHER, 2008).

As soluções propostas, no entanto, ainda apresentavam problemas de sustentabilidade financeira ou eram insuficientes para resolver todas as dimensões dos problemas socioambientais. Diante disso, algumas organizações híbridas começam a ser criadas. São 
organizações capazes de gerar recursos financeiros suficientes para garantir perenidade e gerar soluções em formas de produtos ou serviços voltados para as necessidades da população de baixa renda, obedecendo, assim, regras de mercado. Essas organizações são chamadas de negócios sociais (COMINI et al., 2011).

Esse tipo de negócio possui origem e atuações diversificadas nos diferentes continentes. Nos EUA, Estados Unidos da América, por exemplo, as organizações nascem como uma alternativa atraente para utilizar os recursos de ações filantrópicas e têm um perfil mais agressivo, buscando escalabilidade e soluções de grande porte. Na Europa, essas organizações surgem de uma perspectiva de algumas associações de incrementar os serviços que seriam oferecidos pelo governo e possuem uma estrutura participativa e com alto envolvimento dos stakeholders (partes interessadas). Na Ásia, as soluções visam o combate à pobreza, presente na maioria dos países, e se caracterizam por apresentar soluções inovadoras que servem de exemplo para outras partes do mundo. No Brasil e em outros países em desenvolvimento, as soluções procuram alternativas a problemas gerados pela falta de acesso igualitário para todas as classes sociais e apresentam uma grande diversidade de modelos de negócios e de setores de atuação (COMINI; BARKI; AGUIAR, 2012).

Esses negócios necessitam de novos agentes e de uma forma diferente de se relacionar com outras organizações, portanto, formam um novo ecossistema. Um ecossistema é formado pela interação de empresas em volta de determinada inovação, trabalhando competitivamente e cooperativamente para a criação de novos produtos e para a satisfação das demandas de clientes (MOORE, 1993). A característica particular desse ecossistema de negócios sociais é o consenso em balancear a geração de valor social e a geração de valor econômico, criando negócios que tragam soluções efetivas e capazes de gerar receitas e até distribuição de lucros em alguns casos (COMINI et al., 2011).

Por conta desses elementos, muitas ferramentas, modelos de negócios, formas de gestão, foram adaptadas a esse novo tipo de empreendimento. Portanto, o ecossistema de negócios sociais carrega muitos aspectos empresariais com um olhar diferenciado sobre as consequências socioambientais do negócio e com a intenção de criar valor e soluções para a população de baixa renda, que, por muito tempo, foi preterida pelas empresas privadas (PRAHALAD, 2004). 
As modificações em prol desse modelo mais social reflete fortemente no sistema de métricas adotado pelos negócios e pelas outras organizações que interagem com os mesmos. Os indicadores tornam-se uma forma de linguagem de comunicação entre os agentes do ecossistema, para que dessa forma seja possível monitorar o desempenho das organizações e identificar de que forma os negócios realmente estão cumprindo o objetivo de geração de valor misto e de que forma isto está sendo realizado. Essas métricas são compostas por indicadores do segundo e do terceiro setores. Usam-se indicadores econômico-financeiros originários de empresas privadas e indicadores socioambientais provenientes das análises feitas de projetos sociais.

A avaliação de geração de valor social é um tema relativamente novo se comparado com as formas de avaliação para a geração de valor econômico, portanto, ainda apresenta uma série de desafios, principalmente quando separamos input e outputs, mais simples e tangíveis, de outcomes e impacto, indicadores mais complexos e intangíveis.

Há ainda desafios como a inadequação das práticas de mensuração; a falta de volume de informações organizadas e de histórico para validar premissas; barreiras metodológicas ou operacionais; nível de governança ainda deficitário para a autenticação das informações recebidas; processos e sistemas ainda ineficientes e custosos; e a grande variedade de modelos de negócios.

Além das dificuldades de escolha dos indicadores, para Oliveira Filho, Kiyama e Comini (2011), é necessário monitorar a implementação e o desempenho de curto e médio prazo dos indicadores intermediários e finais para realizar o acompanhamento efetivo dos benefícios gerados por determinada iniciativa. O que não é uma tarefa simples, porém importante para o usufruto dos benefícios das métricas.

A escolha de indicadores quantitativos e qualitativos também causa polêmica. $\mathrm{O}$ método quantitativo é mais generalista e apresenta uma facilidade maior de comparações; contudo, muitas das métricas utilizadas são qualitativas, uma vez que são necessárias para o entendimento dos detalhes e das formas de funcionamento de determinado negócio, e proporcionam a possibilidade de isolar e medir apenas os efeitos de uma iniciativa avaliada (OLIVEIRA FILHO; KIYAMA; COMINI, 2011). 
Os sistemas de avaliação presentes ainda não são suficientes e apresentam uma série de falhas, espaços para complementaridade entre eles, e vazios. Entretanto, é necessário ressaltar a importância do exercício de criar uma metodologia e colocá-la à prova para receber feedbacks e implantar melhorias. As mais utilizadas até 2013 são o IRIS, Impact Reporting and Investment Standards, de 2008; o GIIRS, Global Impact Investing Ratings System, de 2009; e o SROI, Social Return on Investment, de 2006. Levando em consideração o tempo, vê-se que ainda há muito a evoluir, entretanto, é necessário relembrar que os indicadores têm suas limitações e podem ajudar a descrever um fenômeno, mas que em determinados casos não são suficientes para demonstrar a realidade de determinada ação (CALIL, 2012). Assim como qualquer outro meio de simplificar a realidade, como um modelo matemático, os sistemas de métricas devem ser suficientemente bons para medir as dimensões do objetivo e razoavelmente simples para que seja gerada uma descrição sintética que possibilite decisões.

Os stakeholders, de maneira geral, querem e precisam mensurar os impactos sociais para que tenham segurança se mudanças benéficas estão sendo geradas, entretanto, existem necessidades e visões diferentes, mesmo quando os objetivos estão alinhados. Portanto, nem sempre é possível olhar determinada iniciativa baseada nos mesmos indicadores. O que parece importante é que ambos caminhem em direção um do outro para que formas mais justas e menos reducionistas de se realizar avaliações e comparações sejam encontradas. Para que isso aconteça é necessário ter consciência das limitações e valorizar os benefícios proporcionados pelo uso de métricas e pelas ferramentas de avaliação de impacto socioambiental.

Uma das áreas que apresenta grande demanda para os negócios sociais, que necessita de métricas que atendam aos stakeholders e de iniciativas com bons resultados é a saúde. Apesar de a Constituição Federal de 1988 definir acesso à saúde como direito do cidadão e dever do Estado, o sistema do país é incapaz de atender à demanda da população. Esse fato faz com que os gastos com saúde representem os maiores gastos da população com serviços que deveriam ser obrigações do Estado, afetando principalmente a população de baixa renda. No entanto, na visão dos empreendedores de negócios sociais isso se torna uma oportunidade de negócio atraente (TORRES, 2011).

Dentro dessas perspectivas, e considerando a importância do setor de saúde no desenvolvimento como gerador de liberdade, este trabalho visa descrever como a geração de 
valor social é avaliada pelos negócios sociais focados em saúde no Brasil, pelos próprios empreendedores e pelas organizações de apoio desse ecossistema. E desta forma, realizar a gestão estratégica efetiva e o balanceamento entre a geração de valor social e valor econômico de acordo com a finalidade da organização.

O Capítulo 2 deste trabalho detalha as definições e a formação dos negócios sociais, assim como aprofunda a questão da importância da criação de um ecossistema forte e completo que consiga fazer com que esta modalidade de negócios tenha um ambiente favorável e capaz de gerar mais inovações e soluções para os problemas sociais em nosso país. O Capítulo 3 se dedica às questões das métricas e como cada um dos agentes do ecossistema as utiliza. $\mathrm{O}$ contexto atual do sistema de saúde brasileiro, explicado no Capítulo 4, identifica as principais falhas no atendimento à população de baixa renda, e servirá de subsídio para analisar os negócios que objetivam solucionar essas questões. O Capítulo 5, aborda a escolha da metodologia escolhida para este trabalho. No Capítulo 6, os dados das empresas e das coletas são demonstrados e analisados, para que as conclusões sejam demonstradas no Capítulo 7. 


\section{DEBATE SOBRE NEGÓCIOS SOCIAIS}

\subsection{Contextualização}

Até a década de 1990, crescimento econômico era considerado sinônimo de desenvolvimento, e este, por sua vez, era medido através do PIB, Produto Interno Bruto, ou do Produto Nacional Bruto. Essa visão, no entanto, foi sendo alterada ao longo do tempo, visto que paralelamente ao grande crescimento econômico havia, em diversas ocasiões, desemprego, exclusão, miséria e destruição ambiental.

Um grande marco da discussão e reavaliação do conceito de desenvolvimento foi a Conferência das Nações Unidas sobre o Meio Ambiente e o Desenvolvimento, conhecida também como ECO-92 ou Rio-92, na cidade do Rio de Janeiro, em 1992. Essa conferência teve papel importante na integração de três pilares ao conceito de desenvolvimento sustentável: econômico, social e ambiental. Dessa forma, foi formalizada a visão de que os negócios devem ser economicamente viáveis, ecologicamente corretos e socialmente justos. Ou seja, devem garantir o que foi chamado de triple bottom line ou tripé da sustentabilidade.

Alguns economistas que discordam da visão de desenvolvimento baseada apenas no aumento de atividades econômicas geradoras de renda utilizam outras formas de conceituá-la. Sen (2010, p. 10) afirma “[...] O desenvolvimento consiste na eliminação de privações de liberdade que limitam as escolhas e as oportunidades das pessoas de exercer ponderadamente sua condição de agente."

O autor discorda do uso do PIB como instrumento de mensuração e de controle do desenvolvimento econômico. Da mesma linha de pensamento compartilha Abramovay (2003, p. 7): "Os elementos que formam o PIB oferecem, apenas, uma espécie de leque virtual de possibilidades: mas os fins são os "funcionamentos", o que, de fato, os indivíduos fazem com o resultado das atividades sociais.”

Em razão das dificuldades do crescimento econômico no impulso ao desenvolvimento, Sen (2010) introduziu o conceito de liberdade. Tanto o aumento do PIB como das rendas pessoais são considerados fatores importantes para alcançar a liberdade, mas não os únicos, e muitas 
vezes mascaram a realidade. A visão de desenvolvimento econômico é dissociada da visão de liberdade e desenvolvimento social, e, de acordo com esse autor, a renda não é o fator mais importante. A liberdade na visão de Sen (2010) depende de diversos outros fatores além da renda, como acesso à saúde, educação, direitos civis, moradia, preservação ambiental e geração de renda.

"Superar a pobreza não é apenas dispor de certos recursos materiais: é, antes de tudo, ter acesso a novas oportunidades com base na aquisição e no exercício de capacidades (capabilities) que não faziam parte dos hábitos sociais (beings e doings, os seres e os fazeres) até então prevalecentes." (ABRAMOVAY, 2003, p. 7).

Sachs (1993) foi um dos precursores dessa visão diferenciada sobre desenvolvimento que levantou a importância da dimensão espacial e cultural, bem como da questão social, ambiental e econômica, conforme exposto em seu trabalho:

a) A questão social é definida como a busca da equidade na distribuição de renda e de bens;

b) A questão econômica, por sua vez, é definida como o gerenciamento eficiente na alocação de recursos, considerando um fluxo constante de investimentos públicos e privados, sendo avaliada em termos macrossociais, e não apenas através do critério da rentabilidade empresarial de caráter macroeconômico;

c) $\mathrm{O}$ aspecto ecológico ou ambiental do desenvolvimento sustentável deve ser obtido através de medidas que objetivem a ampliação da capacidade de carga, a capacidade de uso do planeta, a limitação do uso de combustíveis fósseis através de substituição, a redução do volume de resíduos e poluição através da reciclagem, a autolimitação no consumo exagerado de materiais por algumas nações e indivíduos, a intensificação das pesquisas para obtenção de tecnologias mais eficientes e menos poluidoras, além da definição de normas para uma adequada proteção ambiental;

d) Em relação ao aspecto espacial, o autor acredita que deve haver uma configuração ruralurbana mais equilibrada e uma distribuição territorial dos assentamentos humanos e das atividades econômicas;

e) A questão cultural deve ser realizada através da procura de raízes endógenas de processos de modernização e de sistemas agrícolas integrados. Processos que busquem mudanças dentro da continuidade cultural e que traduzam o conceito normativo de 
ecodesenvolvimento em um conjunto de soluções específicas para o local, o ecossistema, a cultura e a área.

É, portanto, a partir da década de 1990, que o conceito de desenvolvimento é ampliado. O conceito de performativity diz que a influência da teoria, das ferramentas e dos frameworks utilizados para descrever ou analisar determinado fenômeno econômico e social são responsáveis por interferir de maneira substancial na performance do mesmo (CALLON, 1998). Ou seja, a maneira como se olha ou a forma de medir determinado fenômeno é fundamental para priorizar determinadas características em detrimento de outras e, dessa forma, alterar o resultado e influenciar as próximas análises; pode, ainda, ser exemplificado pela revisão do PIB como única forma de medir o desenvolvimento do país, o que evidenciou muitos problemas.

As atuações de empresas, governos e organizações do terceiro setor têm sido insuficientes para alcançar esse desenvolvimento preconizado por Sen (2010). As empresas responsáveis pela geração de riquezas chegam a bons resultados financeiros, mas com impactos socioambientais insuficientes. Os governos se mostram, na sua maioria, ineficientes para suprir as necessidades básicas das pessoas de forma equânime e abrangente. $E$ as organizações do terceiro setor muitas vezes têm a sua ação limitada a uma determinada região e poucas condições de resolver sozinha a difícil situação socioambiental acumulada por décadas - o que leva a concluir que atuando dessa forma o sistema não é sustentável, ou seja, produz dificuldades para o desenvolvimento que efetivamente gera liberdade (SEN, 2010).

Os Estados nacionais são atores econômico-sociais fundamentais nos rumos do desenvolvimento, uma vez que são os “[...] principais responsáveis pela regulação da vida social, econômica e política em seus espaços fronteiriços [...]” (CARDOSO JÚNIOR; SANTOS, 2010). De acordo com Pzreworsky (1995, p. 8), “Os Estados respondem às preferências dos cidadãos, os Estados procuram realizar seus próprios objetivos, e, finalmente, os Estados agem segundo o interesse dos que possuem riqueza produtiva." Há, portanto, a expectativa que o governo seja capaz de atuar de forma a estimular o crescimento econômico, na melhoria das condições de vida, na proteção da sustentabilidade dos sistemas ambientais e de produção e na proteção social (CARDOSO JÚNIOR; SANTOS, 2010). Os Estados nacionais, entretanto, nem sempre cumprem esse papel nem atuam como solucionadores dos problemas causados pelas relações econômico-sociais. Fatores como 
excesso de burocracia, interesses políticos, falta de envolvimento da população em questões políticas e na fiscalização das atividades de seus representantes, falta de políticas públicas inovadoras ou do fomento das mesmas, as disparidades regionais, entre outros, parecem dificultar a solução da diversidade de problemas enfrentados pelos governantes.

Outro ponto que se apresenta crítico para a atuação do governo é a forma como as agências reguladoras moldam e limitam o mercado para a atuação de empresas inovadoras, principalmente quando o tema são serviços básicos como saúde e educação. O papel das agências reguladoras também parece complexo, haja vista que ao mesmo tempo em que deve garantir padronização e qualidade nesses serviços, deve também permitir que novas soluções sejam apresentadas e absorvidas nas regras existentes.

As empresas, apesar de gerarem valor econômico e serem atores importantes para o crescimento econômico e desenvolvimento de tecnologia, acabam também gerando externalidades negativas. As atividades econômicas do segundo setor (atividades privadas) geram parte do problema ambiental, e colateralmente também contribuem para alguns problemas sociais como a desigualdade, a marginalização de pessoas a bens e serviços, o incentivo excessivo à urbanização e a alienação do trabalho. Os atores econômicos do setor privado atuam no mercado, que é um mecanismo de fundamentação de regras de trocas pautado pela vontade de indivíduos, e, portanto, atuam para maximizar seus ganhos em uma ótica autointeressada, sem necessariamente contribuir para a mitigação de problemas socioambientais gerados pelas suas atividades.

Nos anos 1990, as empresas, pressionadas por governos, sociedade civil, pelo próprio mercado e por conta de uma maior conscientização de seu papel como agente na busca do desenvolvimento sustentável, intensificaram e aprimoraram as atividades sociais realizadas (FISCHER, 2008). Deu-se início a uma série de atividades de responsabilidade social corporativa com a intenção de reduzir os danos causados pelas atividades econômicas que exercem. Contudo, os dados ainda são insuficientes para demonstrar que as ações das companhias estejam promovendo impactos efetivos (FISCHER, 2008). É importante considerar também fatores como foco e competências das organizações, que em muitos casos precisam ser complementados através de interações com organizações do terceiro setor. Dessa forma, as empresas conseguem ser mais eficientes por investirem de maneira mais consistente e por conseguirem ter um envolvimento maior com os stakeholders envolvidos. 
Na década de 1990, além de um importante crescimento de ações filantrópicas, houve também aumento da atuação das organizações da sociedade civil, notadamente nos países em desenvolvimento (COMINI et al., 2011), denominado terceiro setor. Essas organizações tinham como objetivo atacar problemas socioambientais existentes por meio de atividades fora da lógica de mercado; além disso, pressionavam mudanças em empresas que não apresentavam conduta compatível com os valores e responsabilidades empresariais (MAGALHÃES, 2010). Como é o caso das ações de algumas ONGs, focadas em questões ambientais, que realizam embargos contra determinado produtos.

Por meio de alianças cada vez mais presentes com empresas privadas ou governo, as organizações do terceiro setor muitas vezes conseguem atuar de maneira interessante na resolução das barreiras que freiam o desenvolvimento social. Falta, no entanto, organização, agilidade, foco em resultado e uma gestão mais eficiente para que a velocidade e escala de soluções sejam maiores. Essas organizações também sofrem de problemas de captação de recursos e de continuidade dos aportes, para que as atividades sejam mais perenes.

Com as limitações de atuação do governo em relação à eliminação da pobreza, Prahalad (2004) destacou a importância de iniciativas empresariais lucrativas como uma forma mais efetiva e possível de promover a inclusão de pessoas marginalizadas. Para isso, bastaria que as empresas entendessem o potencial do mercado da Base da Pirâmide (BoP, Bottom of the Pyramid) e se tornassem responsáveis por essa inclusão. A maneira indicada de se realizar isso seria entender a população mais pobre como empreendedores e consumidores conscientes do valor que eles buscam, sendo que a partir disso as empresas multinacionais teriam condições de fornecer os produtos que eles necessitam, lucrando com isso e reduzindo a pobreza.

Apesar de gerarem acesso a alguns produtos, estas nem sempre oferecem valor social significativo (KARNANI, 2007). Um exemplo claro e polêmico mencionado por Prahalad (2004) é o da rede de comércio varejista Casas Bahia, que através de uma política de crédito mais flexível, permite acesso da camada mais pobre da população a bens de consumo, como eletrodomésticos. A análise, porém, leva em conta apenas o desempenho da empresa, e não realiza uma crítica ao endividamento causado ao consumidor que tem a compra facilitada (FISCHER, 2008). 
Com uma visão mais voltada para benefícios sociais, Yunus (2010) também defende a atuação empresarial como uma forma de solução para problemas sociais, mas acredita que as empresas devem utilizar as receitas geradas por meio da atividade econômica para ampliar o acesso a serviços e produtos oferecidos à camada mais pobre.

Embora Prahalad (2004) e Yunus (2010) tenham visões diferentes sobre formas de geração de valor social, há um ponto convergente: iniciativas de mercado, que podem ser uma alternativa para a viabilização de um desenvolvimento econômico social mais inclusivo.

É nesse contexto que surge um tipo de organização híbrida, uma organização que atua entre o segundo e o terceiro setores. São organizações que buscam apresentar os pontos positivos de empresa em termos de estrutura organizacional, de processos, de objetivos, de metas, de gestão e o comprometimento com a resolução de problemas sociais através de soluções inovadoras e que estejam dentro da atividade básica da empresa. São os chamados negócios sociais, negócios inclusivos, empresas sociais, entre outras denominações. As definições desse tipo de negócio serão abordadas no próximo item deste capítulo.

\subsection{Negócios sociais}

Diante de um novo tipo de organização, surge a necessidade de defini-la e entendê-la. Mais do que isso, a definição de uma nomenclatura seria importante - como no caso de empreendedores sociais - para dissolver fronteiras entre setores e atores (DEES, 1998).

[...] No caso dos negócios sociais, não é diferente: abre-se a possibilidade de aproximar organizações da sociedade civil, cooperativas, pequenas, médias ou grandes empresas, financiadores e governo para o debate sobre suas contribuições na diminuição da pobreza, da desigualdade e da exclusão social. (COMINI, 2011, p. 7).

Não há, nesse momento, um consenso sobre a nomenclatura a ser utilizada. A apropriação e a utilização do termo por diferentes atores (empresas, organizações da sociedade civil, bancos de desenvolvimento, aceleradoras, incubadoras, investidores, entre outros) explicam a ambiguidade e a diversidade conceitual no debate sobre negócios sociais. É possível, além da divergência quanto a uma definição, notar uma grande dificuldade e diferentes graus de abrangência para o uso do termo e para classificar empresas dentro desse conceito. Essas 
divergências, todavia, são consideradas comuns para conceitos em formação (COMINI; BARKI; AGUIAR, 2012).

De forma mais abrangente, pode-se dizer que são iniciativas de mercado que criam valor social e econômico dentro da lógica de mercado (COMINI et al., 2011). Pode-se enxergar essa forma de fazer negócios apenas como um tipo específico de empresa privada, como uma organização da sociedade civil que gera seus próprios recursos, ou ainda, de acordo com Young (2008), pode-se dizer que esse tipo de empreendimento é algo importante e distinto da forma clássica de se fazer negócios.

Outra característica na classificação de um determinado tipo de iniciativas é a influência regional. Os termos têm diferenças e definições razoavelmente distintas para classificar novas iniciativas. Essa diversidade ocorre por fatores históricos na formação desse tipo de empresas, na maneira como atuam e como a legislação classifica esse tipo de organização.

Comini (2011, p. 9) afirma que, na Europa, a primeira rede de pesquisa nessa área - EMES European Research Network (Emergence des Enterprises Sociales en Europe) - define que as empresas sociais são "[...] organizações com o objetivo explícito de beneficiar a comunidade, iniciadas por um grupo de cidadãos, nas quais o interesse material dos investidores capitalistas é sujeito a limites [...]". Esta definição advém do histórico no associativismo e cooperativismo, na intenção de resolver um problema em uma área em que o governo poderia atuar (educação, cultura e meio ambiente), e que possuem uma estrutura de governança com alto grau de transparência e de participação das partes interessadas.

Há diversas outras definições utilizadas. De acordo com Comini (2011, p. 10) a Organisation for Economic Co-operation and Development, por exemplo, define como

[...] organizações que buscam metas sociais e econômicas com espírito empreendedor e têm o propósito principal diferente da maximização do lucro. Elas possuem a consecução de metas econômicas e sociais, com as quais tenham a capacidade de trazer soluções inovadoras para problemas de exclusão social e desemprego [...]. 
Apesar das diferenças sutis em relação a outras definiçõos, como a da Social Enterprise Coalition, do Departamento de Comércio e da Indústria do Governo do Reino Unido, existe uma convergência quanto ao propósito de trazer benefícios socioambientais, mais do que focar somente na maximização de lucros. Os lucros devem ser reinvestidos, mas a principal particularidade é o rigor com a governança (COMINI; BARKI; AGUIAR, 2012).

A governança das empresas sociais na Europa segue algumas características relevantes. As organizações são autônomas e, portanto, não estão sujeitas à interferência na gestão de nenhum tipo de investidor, seja ele público ou privado. Dessa forma, os investidores têm a mesma força que qualquer stakeholder. Outra característica importante na governança dessas empresas é a participação das partes interessadas, sejam elas beneficiários, empregados, voluntários, autoridades públicas ou doadores, estimulando, assim, o desenvolvimento local do processo democrático (DEFOURNY; NYSSENS, 2012).

Nos Estados Unidos há uma abordagem diferenciada em relação aos negócios sociais, que têm sua origem baseada na cultura empreendedora e em uma visão menos coletiva. Esta parte da necessidade de organizações do terceiro setor de captarem além das doações que começam a vender produtos e serviços para conseguirem atingir seus objetivos (KERLIN, 2006). Por outro lado, partem do foco de algumas empresas em atuar no mercado da base da pirâmide. Com essa visão mais ampla de negócios sociais, Young (2009) sente a necessidade de aprofundar as definições e separar melhor as possíveis iniciativas que agregam objetivos sociais e econômicos.

Para elaborar uma definição mais clara, Young (2009) identifica e define separadamente tipos de instituições e projetos/iniciativas. Segundo ele, filantropia corporativa é definida como a atuação de uma empresa, com fins econômicos não relacionados com a atividade social. Empresa com fim social, de acordo com ele, é aquela que se utiliza do mercado para conseguir atingir um objetivo social. E empresas que focam na geração de benefícios sociais claros e na remuneração dos stakeholders são denominadas híbridas. O autor ainda pontua os projetos de geração de recursos, utilizados por organizações sem fins lucrativos para complementar a receita; projetos de finalidade social, como o conjunto de ações para geração de soluções para missões sociais; e os projetos híbridos, aqueles que buscam ambos: gerar renda e soluções para problemas sociais. 
Há, portanto, uma diferença fundamental em relação à abordagem europeia, visto que a possibilidade de distribuição de dividendos é considerada. Além disso, em muitos casos as estratégias de mercado para a Base da Pirâmide de Prahalad (2004) são consideradas ações sociais. Outra diferença é que na perspectiva americana há a valorização de se conseguir escala, para que o negócio se torne viável, ponto não enfatizado na Europa com soluções mais locais.

A legislação é um aspecto que deve ser analisado. Nos EUA já existem um movimento de adequação de uma legislação diferenciada para as empresas que têm o propósito de gerar benefícios sociais através de atividades de mercado geradoras de receita e lucro. $\mathrm{O}$ formato legal dessas empresas nos EUA é chamado de L3C, Low-Profit Limited Liability Company, já adotado por nove Estados (BISHOP, 2013). Essa legislação foca na geração de benefícios sociais e deixa a preocupação com o lucro como fator menos importante (COMINI; BARKI; AGUIAR, 2012). Possibilitando a distribuição do lucro, essa empresa deixa de ser uma empresa sem fins lucrativos e passa a ficar mais atraente para investidores que podem ter retorno sobre o capital aplicado.

Essa legislação ainda não é muito abrangente e não é única. Existe também outra forma legal de empresas chamada B-Corporation, Benefit Corporation (COMINI; BARKI; AGUIAR, 2012), também adotada por nove estados (BISHOP, 2013), que difere da L3C na definição mais precisa do que é considerado benefício social e na necessidade de se demonstrar através de alguns parâmetros e/ou através de uma certificação o impacto que está sendo gerado. $\mathrm{O}$ estudo da Bishop (2013) mostra que em dois Estados (Louisiana e Vermont), tanto a L3C quanto a B-Corporation foram adotadas, ratificando a complementaridade das duas legislações.

Nos países em desenvolvimento, como é o caso do Brasil, o foco dos negócios sociais é a resolução de problemas sociais - notadamente a má distribuição de renda, adversidade comum para esses países. Afirmam Márquez, Reficco e Berger (2010) que a SEKN, Social Enterprise Knowledge Network, foi formada em 2001 para ampliar as fronteiras de conhecimento e a prática em empreendimentos sociais através da investigação conjunta, aprendizagem compartilhada, ensino centrado em casos e no fortalecimento das capacidades das instituições de formação gerencial a serviço de suas comunidades. Complementam os autores que a SEKN publicou a obra, Negocios Inclusivos: Iniciativas de Mercado con los 
Pobres de Iberoamerica (2010), que relata mais de 30 casos que geram transformação social produzindo produtos e serviços que incorporam a população de baixa renda não apenas como consumidor, mas também os considerando como fornecedores/produtores.

Essa definição da SEKN é bem abrangente, conforme observado por Comini, Barki e Aguiar (2012), por possibilitar a inclusão de uma grande gama de iniciativas que vão de ONGs, empresas privadas ao setor público. Márquez, Reficco e Berger (2010) também enfatizam a necessidade das empresas sociais de oferecerem produtos e serviços que gerem benefícios sociais claros para também estarem comprometidas com a rentabilidade da iniciativa. Dessa forma, chega-se à seguinte definição - organizações que visam solucionar problemas sociais com eficiência e sustentabilidade financeira por meio de mecanismos de mercado (COMINI et al., 2011).

Outro termo bastante utilizado no Brasil é "Negócios Inclusivos". De acordo com Comini (2011, p. 13-14),

[...] Negócios Inclusivos são aqueles voltados à geração de oportunidades de emprego e renda para grupos com baixa ou nenhuma mobilidade no mercado de trabalho, dentro dos padrões do chamado "trabalho decente" e de forma autossustentável, ou seja, gerando lucratividade para os empreendimentos, e que estabelecem relações com organizações empresariais típicas, quer seja na condição de fornecedores de produtos ou serviços, quer seja na distribuição dessa mesma produção das empresas ou negócios tradicionais.

Essa definição é complementada por "Os negócios inclusivos são um meio de sobrevivência para quem vive na base da pirâmide e uma alternativa viável e eficiente como complemento à assistência tradicional dos governos e à filantropia." (FUNDACIÓN AVINA, 2012).

De acordo com as definições apresentadas, pode-se dizer que na verdade negócios inclusivos podem ser considerados como um tipo específico de negócios sociais, em que se busca, principalmente, a inclusão de pessoas marginalizadas no mercado de trabalho, como é o caso das pessoas com deficiência e a inserção dos integrantes da base da pirâmide na cadeia de valor.

Na visão de Muhammad Yunus, economista e banqueiro bengali, ganhador do prêmio Nobel da Paz de 2006 e responsável pela disseminação do conceito de negócios sociais no mundo, falta na definição acima uma posição clara quanto à apropriação do excedente gerado pela 
atividade econômica exercida. De acordo com Yunus (2010), negócios sociais, além de gerarem soluções para educação, saúde, moradia, entre outros problemas sociais, devem ter o compromisso de utilizar o lucro para reduzir ainda mais a pobreza. Isso significa que os negócios sociais devem reinvestir os lucros para ampliar as soluções desenvolvidas ou serem distribuídos nos casos em que os acionistas estiverem na parcela pobre da população, visto que dessa forma o recurso também estará sendo utilizado na redução da pobreza.

O Quadro 1 sintetiza algumas das diferenças importantes entre as definições regionais.

Quadro 1 - Quadro comparativo entre as abordagens regionais na definição de Negócios Sociais

\begin{tabular}{|c|c|c|c|c|c|}
\hline Região & $\begin{array}{l}\text { Público } \\
\text { atendido }\end{array}$ & Origem & Aspectos legais & $\begin{array}{c}\text { Visão sobre } \\
\text { o uso do } \\
\text { lucro }\end{array}$ & Particularidades \\
\hline Europa & $\begin{array}{l}\text { População } \\
\text { excluída do } \\
\text { processo } \\
\text { produtivo }\end{array}$ & Associativismo & $\begin{array}{c}\text { Existem } \\
\text { legislações } \\
\text { distintas para } \\
\text { cada país } \\
\text { (Modelo } \\
\text { Cooperativo para } \\
\text { França, Portugal, } \\
\text { Espanha e Grécia } \\
\text { e modelo de } \\
\text { empresas sociais } \\
\text { no Reino Unido, } \\
\text { na Bélgica e na } \\
\text { Itália) }\end{array}$ & Reinvestido & $\begin{array}{l}\text { Governança, com } \\
\text { participação ativa } \\
\text { das partes } \\
\text { interessadas }\end{array}$ \\
\hline EUA & $\begin{array}{l}\text { Base da } \\
\text { Pirâmide }\end{array}$ & $\begin{array}{c}\text { Interações entre } \\
\text { empresas com } \\
\text { organizações } \\
\text { filantropas }\end{array}$ & $\begin{array}{c}\text { Existem duas } \\
\text { formas de } \\
\text { empresas (L3C e } \\
B \text {-Corporation) }\end{array}$ & $\begin{array}{l}\text { Pode ser } \\
\text { distribuído } \\
\text { para } \\
\text { acionistas }\end{array}$ & $\begin{array}{l}\text { Possibilidade de } \\
\text { trabalhar em escala }\end{array}$ \\
\hline $\begin{array}{l}\text { América } \\
\text { Latina }\end{array}$ & $\begin{array}{l}\text { Base da } \\
\text { Pirâmide }\end{array}$ & $\begin{array}{l}\text { Combate à } \\
\text { pobreza }\end{array}$ & $\begin{array}{c}\text { Não há legislação } \\
\text { específica }\end{array}$ & Indefinido & $\begin{array}{c}\text { Soluções para } \\
\text { problemas sociais } \\
\text { gerados por } \\
\text { desigualdade e falta } \\
\text { de acesso }\end{array}$ \\
\hline $\begin{array}{c}\text { Ásia } \\
\text { (c/ foco em } \\
\text { Índia e } \\
\text { Bangladesh) }\end{array}$ & $\begin{array}{l}\text { Base da } \\
\text { Pirâmide }\end{array}$ & $\begin{array}{l}\text { Combate à } \\
\text { pobreza }\end{array}$ & $\begin{array}{c}\text { Não há legislação } \\
\text { específica }\end{array}$ & $\begin{array}{c}\text { Sem } \\
\text { distribuição } \\
\text { de lucro }\end{array}$ & $\begin{array}{l}\text { Liberdade de ação } \\
\text { em relação à } \\
\text { regulamentação e } \\
\text { fiscalização } \\
\text { governamental }\end{array}$ \\
\hline
\end{tabular}

FONTE: adaptado de Comini, Barki e Aguiar (2012).

No Brasil, a definição de negócios sociais é mais próxima da visão americana, e com diversidade na categorização. Entretanto, apresenta um viés bem focado na redução da pobreza e da desigualdade social. 
Outro critério que diferencia a definição de negócios sociais refere-se à distribuição de lucro. No Brasil, assim como em um grande número de países, o reinvestimento de excedentes ainda é muito polêmico e não há um consenso sobre como utilizá-lo. Há empreendimentos que acreditam que a distribuição de dividendos para os acionistas, sejam eles de camadas mais pobres ou não, não descaracteriza a iniciativa como um negócio social, entretanto, há outras empresas que seguem a linha do Yunus (2008) e que objetivam utilizar o excedente para reinvestir e ampliar o impacto social almejado, acreditando que quando a empresa entra na lógica de distribuição de lucros, perde autonomia.

Em empresas convencionais tem-se um cenário mais simples, haja vista que a distribuição de lucro é algo comum. Entretanto, ainda há a decisão de quanto e onde reinvestir. Esta decisão deve equilibrar a necessidade de ser atrativa para captação de recursos (financeiros e humanos) e a necessidade do negócio se desenvolver de maneira consistente.

Os negócios sociais apresentam a mesma tensão, entretanto, mostram uma dificuldade a mais. Diferente das empresas convencionais que investem em diversas formas para gerar mais receita ou lucro, nem sempre o reinvestimento na solução de problemas sociais gera o mesmo resultado. Por exemplo, quando um negócio social beneficia pessoas que não podem pagar por determinado produto ou serviço: nesse caso, a alocação de recursos não gera nenhum tipo de receita adicional, entretanto, está alinhado com o propósito socioambiental da organização. Em outros casos as empresas adotam uma estratégia de se tornar viável economicamente, tornando-se mais atrativa para investidores e funcionários, distribuindo lucros com a visão de viabilizar o negócio, ou seja, gerar benefícios sociais. Estas duas visões, no entanto, não reduzem a importância de investimentos no desenvolvimento, aprimoramento e inovação do negócio existente, como em um negócio convencional.

Além da questão de alocação de recursos excedentes, as empresas e recursos ao redor de negócios sociais devem se rearranjar. O ecossistema para empresas convencionais já é algo estabilizado, em que os papéis e as formas de interação já estão definidos. O que não acontece em um ecossistema em formação, como é o caso dos negócios socioambientais, em que há a necessidade de construir um sistema com parâmetros e regras próprias. 


\subsection{Ecossistema}

\subsubsection{Ecossistemas de negócios}

De acordo com Moore (1993), os ecossistemas de negócios podem ser comparados com os ecossistemas biológicos. Na definição biológica, ecossistema (grego oikos, casa + systema, sistema $=$ sistema onde se vive) consiste no conjunto de todos os organismos e todos os fatores abióticos (água, solo, características geográficas, entre outros) que interagem entre eles em uma determinada região. Sua análise busca entender como as comunidades interagem, assim como todas as transferências de materiais e energia entre eles (CHAPIN III, 2012, p. 5). Dessa forma, é possível fazer uma analogia com os negócios e dizer que ecossistema de negócio é a interação de empresas em volta de determinada inovação, trabalhando competitivamente e cooperativamente para a criação de novos produtos, satisfação das demandas de clientes e, eventualmente, gerar inovações (MOORE, 1993).

Na visão de Moore (1993), os ecossistemas de negócios são formados por fornecedores, clientes, concorrentes e líderes. Os líderes são os responsáveis por ditar o padrão tecnológico, mobilizar fornecedores e clientes e conduzir a comercialização. O exemplo citado de líder é a Apple para o ecossistema de computadores pessoais, eletrônicos e comunicação. Reficco e Vernis (2010) ressaltam que o progresso de todas as organizações de determinado ecossistema são interdependentes, e que para que se tenha sucesso em alguma organização, as empresas também precisam evoluir, assim como nos ecossistemas naturais.

O ecossistema apresenta analogia com os clusters, sistemas industriais e redes. Afirmam Ferrary e Granovetter (2009) que muitos frameworks são utilizados para descrever essa relação entre os agentes de determinados negócios. E que é o caso dos "Clusters", de Michael Porter, em Clusters and the New Economics Competition (1998); os "Distritos Industriais", de Alfred Marshall, em Principles of Economics (1890), Michael Piore e Charles Sabel, em The Second Industrial Divide: Possibilities for Prosperity (1984), e Giacomo Becattini, em Italian Industrial Districts: Problems and Perspectives (1991); "Habitat", de Chong-Moon Lee e colaboradores, em The Silicon Valley Edge: A Habitat for Innovation and Entrepreneurship (2000), "Business Ecosystem”, de Marco Iansiti e Roy Levien, em Strategy as Ecology (2004), e "Redes de Inovação", de Anna Lee Saxenian, em Regional Advantage:- Culture and Competition in Silicon Valley and Route 128 (1994). Essas denominações variam 
conforme o autor. Neste trabalho será utilizada a definição de ecossistema, de Moore (1993), por considerar que essa visão é abrangente e didática o suficiente para a realização de analogia com os ecossistemas biológicos e se internalizar a ideia de que as interações entre todos os atores são fatores importantes para tornar algum ecossistema de negócios mais ou menos eficiente.

É importante notar a diferença significativa que existe entre o ecossistema e a cadeia de valor estendida de Porter (1985). Na cadeia de valor, o foco é a empresa, seus fornecedores e seus consumidores, em uma visão que vai da matéria-prima mais elementar até o consumidor final, passando pela relação de compra e venda das empresas e seus processos internos (REFICCO; VERNIS, 2010). Na abordagem de ecossistema, adicionam-se a isso os outros agentes que influenciam estas relações. Além de se olhar os stakeholders internos e externos, como a sociedade civil e a relação destes com as empresas, a visão do ecossistema deve contar com a relação com governo, agências reguladoras, organizações de apoio como Universidades, laboratório de pesquisas, empresa prestadoras de serviços, financiadores e qualquer agente que possa influenciar as transações, conforme a visão que constitui o denominado Diamante de Porter (PORTER, 1989).

Nota-se que existe uma significativa abrangência e diversidade de ecossistemas. Há ecossistemas com alcance mundial, outros mais locais, mas todos demonstram as características de interação entre empresas e agentes que determinam sua formatação e seus líderes.

\subsubsection{Papel dos atores}

O Vale do Silício é o grande objeto de estudo quando o tema é empreendedorismo, pois é lá que o ecossistema é mais desenvolvido, apresenta diversos exemplos de empresas de sucesso, é um ecossistema robusto e duradouro, também utilizado como benchmark e modelo por outros países que querem criar ecossistemas de apoio a startups (empresas nascentes de jovens empreendedores) inovadoras (FERRARY; GRANOVETTER, 2009).

Ferrary e Granovetter (2009), em sua análise da rede complexa formadora do Vale do Silício, o mais exitoso expoente de um ecossistema de empreendedorismo nas últimas décadas, citam 
como os agentes dessa rede - universidades, escritórios de advocacia, empresas de venture capital, laboratórios de pesquisa, grandes empresas de tecnologia, aceleradoras, incubadoras, bancos de investimento, bancos comerciais, escritórios de contabilidade, empresas de consultoria, agências de recrutamento, empresas de relações públicas e veículos de comunicação - estão conectados com outros agentes e são importantes entre eles e tanto para o desenvolvimento do ecossistema como para a criação. De acordo com os autores, há existência de uma rede complexa e multiplexada, em que cada um dos atores pode realizar diferentes papéis na mesma rede. Por exemplo, um executivo de uma empresa de venture capital pode ter sido professor do empreendedor na universidade. $\mathrm{Na}$ visão dos autores há papéis formais e informais que são descritos no Quadro 2.

Quadro 2 - Papel econômico dos agentes no Vale do Silício

\begin{tabular}{|c|c|c|}
\hline Agentes & Papel formal & Papel informal \\
\hline Universidades & $\begin{array}{c}\text { Fomentar inovações; acumular expertise; } \\
\text { prover profissionais treinados }\end{array}$ & $\begin{array}{c}\text { Incubar startups; Promover interação } \\
\text { entre os agentes }\end{array}$ \\
\hline Grandes empresas & $\begin{array}{l}\text { Fomentar e desenvolver inovações; } \\
\text { acumular expertise }\end{array}$ & $\begin{array}{l}\text { Incubar startups; adquirir startups; } \\
\text { realizar parcerias com startup; prover } \\
\text { profissionais treinados; Promover } \\
\text { interação entre os agentes }\end{array}$ \\
\hline $\begin{array}{c}\text { Laboratórios de } \\
\text { pesquisa }\end{array}$ & Fomentar inovações; acumular expertise & $\begin{array}{c}\text { Incubar startups; Promover interação } \\
\text { entre os agentes }\end{array}$ \\
\hline $\begin{array}{c}\text { Fundos de venture } \\
\text { capital }\end{array}$ & Financiar startups & $\begin{array}{c}\text { Selecionar startup; Acumular } \\
\text { conhecimento sobre empreendedorismo; } \\
\text { Inserir startups no mercado; certificar } \\
\text { startups; gerar relacionamento nos } \\
\text { segmentos } \\
\end{array}$ \\
\hline $\begin{array}{c}\text { Escritórios de } \\
\text { advocacia }\end{array}$ & $\begin{array}{c}\text { Acumular conhecimento legal; Lidar com } \\
\text { problemas legais }\end{array}$ & $\begin{array}{l}\text { Inserir startups no mercado; gerar } \\
\text { relacionamento nos segmentos }\end{array}$ \\
\hline $\begin{array}{l}\text { Agências de } \\
\text { recrutamento }\end{array}$ & Estimular o mercado de trabalho & Gerar relacionamento nos segmentos \\
\hline $\begin{array}{l}\text { Empresas de } \\
\text { relações públicas }\end{array}$ & Gerar publicidade para startups & Gerar relacionamento nos segmentos \\
\hline Mídia & Informar sobre startups & $\begin{array}{c}\text { Gerar publicidade para startups; sustentar } \\
\text { a cultura do empreendedorismo }\end{array}$ \\
\hline $\begin{array}{l}\text { Empresas de } \\
\text { consultoria }\end{array}$ & $\begin{array}{l}\text { Acumular conhecimento de negócios; } \\
\text { Fornecer conhecimento para startups }\end{array}$ & $\begin{array}{c}\text { Prover profissionais treinados, oferecer } \\
\text { treinamento técnico }\end{array}$ \\
\hline $\begin{array}{l}\text { Escritório de } \\
\text { contabilidade }\end{array}$ & $\begin{array}{c}\text { Acumular conhecimento sobre } \\
\text { contabilidade; lidar com questões de } \\
\text { contabilidade } \\
\end{array}$ & \\
\hline $\begin{array}{c}\text { Bancos de } \\
\text { Investimento }\end{array}$ & $\begin{array}{c}\text { Organizar Oferta Pública Inicial - IPO, } \\
\text { Initial Public Offering - para startups; } \\
\text { Organizar aquisições de startups } \\
\end{array}$ & Certificar startups \\
\hline Bancos Comerciais & Possibilitar transações financeiras & \\
\hline
\end{tabular}

FONTE: adaptado de Ferrary e Granovetter (2009).

As empresas de venture capital podem ser consideradas as mais importantes agentes do ecossistema do Vale do Silício, atuam como Hubs (centro de distribuição de relações), uma 
vez que quase todas as empresas nascentes que se desenvolveram e se tornaram grandes corporações receberam financiamento dessas instituições. Além disso, é destacável que quando comparado com outros ecossistemas, o grande diferencial do Vale do Silício não são as universidades, as ligações com grandes empresas ou os laboratórios avançados, e sim a presença massiva de empresas de venture capital (HELLMANN, 2000) que, de acordo com Ferrary e Granovetter (2009), são muito importantes pois são responsáveis por financiar, selecionar, gerar aprendizado coletivo, incorporar empresas em ecossistemas mais amplos e sinalizar as empresas mais aptas.

Além dessas características, é importante ressaltar que as inovações que acontecem no Vale do Silício ocorrem graças à completude de atores e à incorporação de agentes interdependentes e heterogêneos (FERRARY; GRANOVETTER, 2009). A robustez do Vale do Silício tem como um dos principais fatores a quantidade de empresas de venture capital presentes nessa rede e as interações que elas proporcionam. Em 2006, 28 das 30 empresas que mais empregam funcionários do Vale do Silício receberam investimento de venture capital.

O Vale do Silício é o mais completo exemplo de um ecossistema capaz de gerar inovação por longo período de tempo, atravessando crises e sendo o benchmark utilizado pelos países que querem desenvolver empresas inovadoras. Entretanto, conforme apresentado por Isenberg (2010), esse modelo não é passível de cópia, por ser necessário identificar as condições e características locais. O que também é observado em Ferrary e Granovetter (2009), por se tratar de um sistema complexo e único devido à formação da rede composta por seus integrantes, não sendo possível replicá-las.

É necessário observar que os papéis descritos no Quadro 2 são específicos para o Vale do Silício, mas podem servir de parâmetros para os negócios sociais. Para o setor de negócios sociais é muito relevante o papel das organizações de apoio, em que se incluem aceleradoras, incubadoras, entre outras. Estas atuam na formação do ecossistema, para que as peças sejam agrupadas e comecem a desenvolver alguma forma de trabalhar juntas. Também são responsáveis pelo capital semente (seja ele capital financeiro, social, tecnológico, entre outros) - que irá nutrir e fortalecer o ecossistema (REFICCO; VERNIS, 2010). 


\subsubsection{Ecossistema de negócios sociais}

No ecossistema de negócios sociais, por ser um ecossistema em estágio inicial, há muitos gargalos, desde o acesso a financiamento como de capacitação e formação de pessoas (MOORE, 1993). Nesse contexto, é importante o papel das organizações de apoio, que devem prover: recursos financeiros, conhecimento de gestão, capacitação e, principalmente, articular com agências governamentais para estabelecer as "regras do jogo" (REFICCO; VERNIS, 2010).

Portanto, o contexto estrutural em ecossistemas em formação, analogia às condições contextuais dos ecossistemas naturais (ar, água, geografia, outros), é ainda mais relevante (REFICCO; VERNIS, 2010). Ainda há uma série de indefinições quanto à regulamentação das empresas sociais, notadamente no Brasil, que dificultam na clareza do espectro de atuação que estas empresas podem atuar. Pensando por setor (educação, saúde, moradia, entre outras) essa visão fica ainda mais nebulosa. A interação com os órgãos reguladores, também parte do ecossistema, são grandes desafios para a atuação de empresas, notadamente na área da saúde, devido à falta de legislação e regulação claras e próprias para estes tipos de iniciativas.

As organizações de suporte podem realizar papéis ainda mais importantes em determinados ecossistemas. Essas organizações envolvem e consolidam o ecossistema através de cursos de formação e capacitação, investimentos, doações, promoção de encontros e ambientes de discussão, estímulos à entrada de membros, promovendo envolvimento de universitários, programas de aceleração e suporte a novos negócios, envolvimento de empresas tradicionais (não sociais) de mercados relacionados e ações para a criação da identidade do ecossistema. Ainda, algumas ações mais focadas em desenvolver as iniciativas, tornando-as mais eficientes e lucrativas, outras atividades com a intenção de formar pessoas para atuar no setor, além de iniciativas que visam aumentar o número de pessoas que conhecem o setor.

Essas organizações, também chamadas de "pivô", são organizações que promovem a criação efetiva e o desenvolvimento do ecossistema (REFICCO; VERNIS, 2010). No Brasil, tem-se, entre outras, organizações "pivô" como o grupo de empresas Artemisia, Potencia Ventures, ${ }^{1}$

\footnotetext{
${ }^{1}$ Organização que oferece capital financeiro e intelectual para o desenvolvimento de ecossistemas de negócios em mercados emergentes, cujos produtos e serviços contribuam para melhorar a qualidade de vida de pessoas de baixa renda (POTENCIA VENTURES; PROSPECTIVA, 2012).
} 
Vox Capital, Avina e o polo Ande. Em 2011, essas empresas realizaram um mapeamento de negócios sociais de pequeno e médio porte no Brasil.

O mapeamento realizado teve como objetivo identificar atores (negócios, incubadoras, aceleradoras, fundos de investimentos) que trabalham para a redução da pobreza, e analisar operações, desempenho e impacto e o relacionamento com os atores do ecossistema (FUNDAÇÃO AVINA; POTENCIA VENTURES; ASPEN NETWORK OF DEVELOPMENT ENTREPRENEURS POLO BRASIL, 2011), com a finalidade de trabalhar na promoção e na divulgação das atividades do campo. Neste estudo foram identificadas 884 organizações que têm como objetivo reduzir a pobreza. Entre eles, 140 negócios sociais/inclusivos, 60 incubadoras, 24 aceleradoras e 15 investidores, além de 645 iniciativas de geração de renda.

O estudo, além de identificar atores, realizou a descrição do perfil dos negócios, considerando fatores geográficos, setor de atuação foco, características organizacionais, modelo de gestão, características de produtos e mercado, forma de gerir impacto social, modelo de crescimento e forma de financiamento. Pode-se observar uma concentração na região sudeste, atuando principalmente com educação, serviços financeiros (microcrédito) e cultura, a maioria fundada nos anos 2000; 68\% geram impactos através de acesso a produtos e inclui pessoas de baixa renda na cadeia; $72 \%$ atuam na área de serviços, e seus clientes são pessoas físicas e empresas médias e pequenas, enquanto $64 \%$ não precisam de doações.

Além da visão descritiva, o estudo mostra tendências para cada uma das regiões e setores apresentados. O mapeamento indicou a necessidade de refinar os conceitos de negócios sociais e possibilidade de incluir outros negócios que geram impacto social e que ainda não são considerados como negócios sociais. Isto, de acordo com o mesmo estudo, não deve gerar uma definição rígida, mas algo abrangente e unificado. Outra necessidade clara é a de aumentar a mensuração de impacto nos negócios mapeados e da criação de métricas comuns para medir o impacto social gerado. 
O papel de mensuração e criação de indicadores que permeiem os agentes do ecossistema de negócios sociais também fica a cargo das organizações de apoio. De acordo com Reficco e Vernis (2010), o objetivo destas encontra um alinhamento muito grande com a visão acadêmica e apresenta um potencial muito grande no ecossistema, uma vez que essas organizações visam:

a) Incentivar aos participantes. Criar plataformas organizacionais com a finalidade de alinhar a visão e as decisões de investimento do ecossistema, auxiliando as demais empresas a atingir os objetivos de maneira mais rápida;

b) Construir as relações com os envolvidos em acordos de benefícios recíprocos. Criar ações que realmente mobilizem os stakeholders e que gerem resultados práticos;

c) Desenvolver um sistema estável. Ou seja, desenvolver condições para que as empresas sejam vistas de maneira mais segura para investidores e possíveis ingressantes no ecossistema;

d) Diminuir custos de transação. Desenvolver canais eficientes de trocas comerciais e de informações entre as organizações;

e) Otimizar a infraestrutura existente. Promover relacionamentos sociais entre os participantes do ecossistema;

f) Influenciar o entorno. Realizar ações que facilitem que barreiras geradas pelo contexto estrutural sejam ultrapassadas.

As ações que caracterizam o ecossistema são o conjunto de medidas que criam uma visão própria do setor. Uma dessas medidas são as métricas utilizadas para comparar negócios e mensurar o sucesso das empresas. Esses indicadores variam para cada setor, os indicadores do setor bancário são diferentes dos indicadores do setor industrial, que, por sua vez, são diferentes dos que definem empresas de tecnologia de sucesso. No caso de negócios sociais, um campo em construção, essas características ainda precisam ser definidas. 


\section{MÉTRICAS PARA NEGÓCIOS SOCIAIS}

\subsection{Introdução}

Os indicadores são itens utilizados constantemente por qualquer tipo de organização. O termo em latim indicatore significa "aquilo que indica ou serve de indicação" (CALIL, 2012). As organizações os utilizam como referências, baseadas em índices ou descrições sintéticas, para o conhecimento e compreensão de fenômenos complexos de diferentes naturezas. Entretanto, dependendo do fenômeno que se quer entender, é necessário que exista um grande cuidado para a escolha de indicadores que realmente proporcionem atingir este objetivo.

Há alguns anos Kaplan e Norton (1992) notaram que as métricas financeiras não eram suficientes para gerir os negócios. Em uma pesquisa com 12 empresas pelo período de um ano, eles perceberam que era necessário olhar outros indicadores para que a empresa evoluísse. Foi, então, com a intenção de complementar as métricas que direcionam decisões e melhorar os resultados das empresas que foi criado o Balanced Scoredcard (sistema de gestão de desempenho), uma forma de integrar a perspectiva interna, a perspectiva dos clientes, a visão financeira e a perspectiva de inovação e aprendizado.

A contribuição dos autores sobre a importância das métricas na tomada de decisão é de extrema relevância, visto que os indicadores financeiros não medem algumas dimensões importantes para a sustentabilidade dos negócios. As empresas constataram que o Balanced Scoredcard traz inúmeros benefícios para os negócios no curto, médio e longo prazos, em relação ao crescimento, competitividade e melhoria dos indicadores financeiros. Isso se deve ao fato de que com indicadores mais abrangentes as decisões são feitas de maneira mais ampla, são mais eficientes e mais conectadas à estratégia (KAPLAN; NORTON, 1992).

Os indicadores, portanto, tornam-se parte imprescindível para a estratégia, o que a deixa mais clara ao possibilitar a comunicação por toda a empresa, alinhar as estratégias de unidades de negócio e os objetivos pessoais com a estratégia central, conectar objetivos de longo prazo com os orçamentos anuais, identificar novas iniciativas e conduzir revisões de desempenho para melhorar a estratégia (KAPLAN; NORTON, 1992). Portanto, os indicadores são de extrema importância para que os objetivos das organizações sejam atingidos. Mais que uma 
ferramenta estratégica, é ferramenta muito útil para comunicação e integração dos envolvidos com a atividade da empresa, sejam eles internos ou externos.

Há também a necessidade de entender que os indicadores possuem algumas limitações. Há um caráter restritivo e reducionista, ou seja, nem sempre é possível transmitir através de um índice, ou um número, a complexidade de determinado fenômeno (CALIL, 2012). Isso pode acontecer mesmo com indicadores financeiros, que são altamente difundidos e aceitos. Por exemplo, uma empresa pode ter aumentado o faturamento, porém não ser rentável ou não ter aumentado o market share (participação de mercado).

A escolha das métricas corretas e a frequência de coleta de dados ainda é um assunto em desenvolvimento, principalmente quando se está fora do domínio financeiro que já está razoavelmente estabelecido e que segue a padrões internacionais. Essa dificuldade na formulação de indicadores é amplificada quando estamos falando de métricas que são destinadas a entender efeitos socioambientais de determinadas ações.

Em seu trabalho sobre indicadores, Calil (2012, p. 63) ressalta algumas limitações apontadas pelos indicadores, tais como:

- As tendências a reduzir os fenômenos complexos às suas partes mais simples ou visíveis, muitas vezes apresentadas sob a forma de medidas quantitativas que pouco podem informar sobre a natureza do fenômeno, e menos ainda sobre o "como" e o "porque" de sua variação em uma intervenção concreta;

- O risco de querer controlar processo que por sua própria natureza são imprevisíveis e incertos e de congelá-los pela ótica e expectativas predefinidas;

- A dificuldade de traduzir mudanças de natureza intangível em linguagem compreensível para diferentes públicos e de atribuir significados às observações feitas.

Essas dificuldades referentes a formas de avaliação e de formulação dos indicadores vêm sendo observadas desde a década de 1990 pelas organizações sociais, principalmente das que buscavam parcerias ou doadores. A adoção de indicadores para o acompanhamento de projetos sociais garante a credibilidade, melhoria e clareza nas tomadas de decisão (CALIL, 2012). A discussão de "como" medir e "o que" medir não é trivial e não tem uma resposta simples, mas diversas organizações já vêm trabalhando seriamente na mensuração dos resultados destas empresas, criando ferramentas capazes de identificar as transformações e mudanças que determinada iniciativa produz em determinado ambiente. 
O Instituto Fonte é uma das organizações líderes na mobilização para a criação de metodologias para a avaliação de resultados de projetos sociais. Um dos trabalhos realizados pelo instituto, em conjunto com a Fundação Itaú Social, teve o objetivo de mapear quanto e como as ONGs brasileiras realizam avaliação de seus projetos e programas sociais e, também, de conhecer motivações, desafios e tendências da avaliação de projetos e programas sociais no Brasil (INSTITUTO FONTE, 2010). Na pesquisa foram entrevistadas 363 ONGs em todo o país, e chegou-se a seis principais desafios da avaliação de projetos socioambientais no Brasil, são eles: 1) Construção de indicadores para programas e projetos; 2) Desenvolvimento de modelos e práticas de avaliação participativa; 3) Fortalecer o sentido e a utilidade da avaliação para organizações que as realizam; 4) Formar ONGs em avaliação para fortalecer suas práticas de avaliação interna; 5) Formar profissionais para atuar como avaliadores; 6) Financiar avaliações.

No levantamento realizado foram identificadas tendências da avaliação de projetos e iniciativas socioambientais, sejam elas de governo, negócios sociais ou empresas privadas, complementadas pelo estudo feito pelas mesmas organizações (INSTITUTO FONTE, 2009). As tendências identificadas são:

a) Adoção de abordagem participativa na avaliação e formulação de indicadores;

b) Desenvolvimento de novas abordagens e processos para a avaliação;

c) Aumento na demanda por avaliações no Brasil;

d) Possibilidade de fortalecimento financeiro e técnico da área;

e) Desenvolver formatos de avaliação que proporcionem aprendizagem;

f) Estímulo à atuação de avaliadores como responsáveis pela mobilização de stakeholders;

g) Espaço crescente para a atuação de avaliadores externos;

h) Aprofundamento do debate técnico ao redor da avaliação; 
i) Espaço para a produção de pesquisas em avaliação, o que dependerá centralmente da atitude das universidades.

Um ponto que é ressaltado nesses trabalhos sobre avaliação de projetos socioambientais é a importância do processo de formulação das métricas. Para que a escolha de indicadores seja feita é necessário que as intenções do projeto estejam refletidas na formulação dos indicadores (CALIL, 2012), assim como é importante entender a necessidade pela qual se quer entender melhor determinados fenômenos e contar com a participação dos stakeholders envolvidos.

Nos negócios sociais esses problemas são exponenciados, visto que as medidas de impacto socioambiental ainda estão em processo de desenvolvimento e são consideravelmente mais complexas e menos cartesianas que os indicadores normalmente utilizados pelas empresas. Além disso, é necessário entender como o valor econômico e o valor social gerados se integram e como são formados em conjunto. Os negócios sociais, de acordo com BuggLevine e Emerson (2011), devem gerar valores mesclados (blended value), ou seja, devem combinar homogeneamente geração de receita com benefícios socioambientais. Essa mistura de objetivos e resultados aumenta a complexidade e a necessidade de outra visão para indicadores.

\subsection{Geração de valor social}

Valor Social não é um conceito que tem uma definição unânime e consensual; isto torna a sua mensuração ainda mais complexa. Portocarrero e Delgado (2010) sintetizaram diferentes abordagens. Valor social é, de acordo com a definição escolhida, a busca de progresso Social mediante a remoção das barreiras que dificultam a inclusão, a ajuda aos temporariamente debilitados ou que carecem de voz própria, e a mitigação dos efeitos secundários indesejáveis da atividade econômica.

Uma grande dificuldade dos negócios sociais é mensurar o seu impacto. O Banco Mundial desenvolveu uma metodologia que foi amplamente disseminada para avaliar projetos sociais (KHANDKER; KOOLWAL; SAMAD, 2010). Essa metodologia utiliza o framework M\&E (Measure and Evaluation; Medidas e Avaliação) e classifica os indicadores em dois grandes 
grupos indicadores intermediários (inputs e outputs) e indicadores finais (outcomes e impacts) (Figura 1).

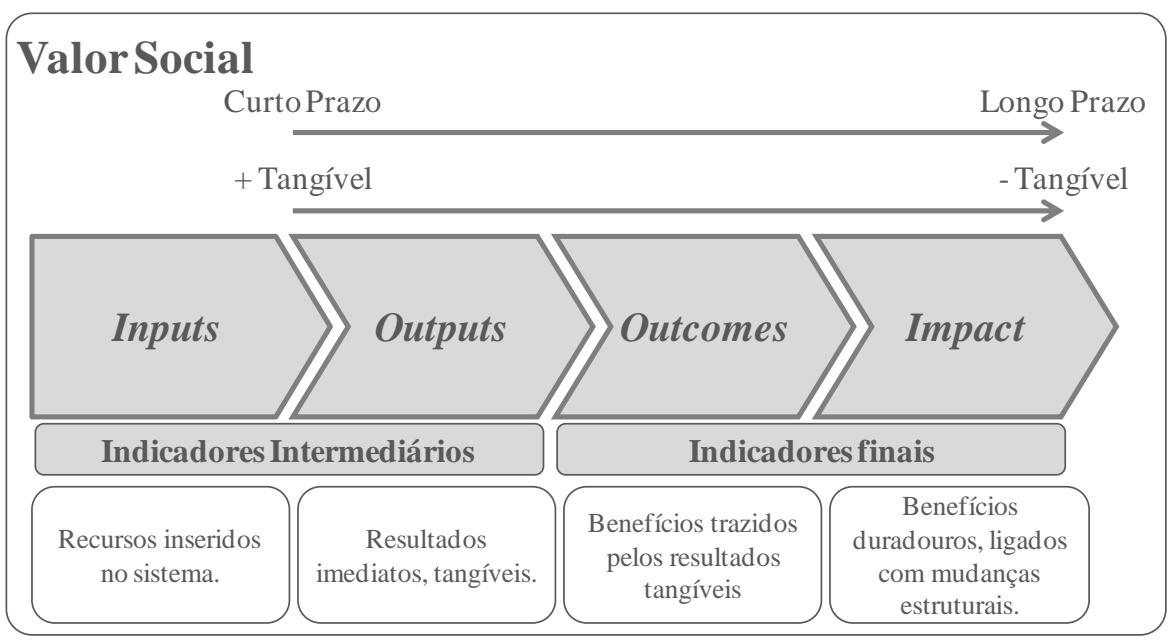

Figura 1: Valor Social

FONTE: adapatado de Khandker, Koolwal e Samad (2010) por Oliveira Filho, Kiyama e Comini (2011).

Os indicadores intermediários são utilizados para realizar a gestão dos projetos, para entender o que deve ser modificado, sendo que o foco está nos processos para que se tenham resultados melhores. Os indicadores intermediários são divididos em inputs e outputs. Os inputs são todos os recursos colocados em prol da iniciativa, tudo que faz com que a ação seja iniciada, podem ser recursos financeiros, recursos humanos, tempo, entre outros. Os outputs são os resultados mais evidentes de determinada iniciativa, são resultados imediatos aos inputs, como o número de pessoas que aderem a determinado projeto.

Os indicadores finais medem os resultados. Demandam análises mais cuidadosas e que são mais difíceis de mensurar, haja vista demonstrarem benefícios menos tangíveis, menos evidentes e com maior dificuldade de quantificação, ou seja, mais distantes da analogia com resultados financeiros. Os indicadores finais são divididos em outcomes e impacto social.

Outcomes são os efeitos causados pelos inputs e pelos outputs. A diferença para os outputs é que eles são mais profundos, ou seja, vão além dos resultados imediatos, são métricas que devem refletir o resultado do projeto (OLIVEIRA FILHO; KIYAMA; COMINI, 2011). São menos tangíveis, como foi dito e, portanto, dependem mais do desenvolvimento de ferramentas e também de um interesse maior em mensurá-los. No exemplo citado do Banco 
Pérola, banco de microcrédito produtivo orientado focado em jovens do interior paulista, um outcome a ser mensurado é a criação de novas empresas após o financiamento, assim como os empregos gerados por essa empresa.

Impacto social pode ser definido como o conjunto de efeitos de uma atividade no tecido social de uma determinada comunidade e suas influências no bem-estar dos indivíduos e famílias que a compõe (OLIVEIRA FILHO; KIYAMA; COMINI, 2011). Esses efeitos podem ser positivos, ou seja, melhorar o bem-estar, ou negativos, reduzir o bem-estar.

O que se pode verificar é que a escolha das métricas e a compreensão do que se deseja entender é muito importante para medir corretamente o quanto o objetivo de impacto está sendo atingido (OLIVEIRA FILHO; KIYAMA; COMINI, 2011). A definição de impacto utilizada pelos autores faz com que se pense nele como o fim, ou seja, como o objetivo final de determinada iniciativa. Portanto, torna-se algo mais subjetivo, mais intangível.

Outra preocupação é separar as causas responsáveis pela geração de impacto, ou seja, identificar qual a importância da geração de impacto da iniciativa avaliada sem considerar os fatores externos que contribuíram para isso (OLIVEIRA FILHO; KIYAMA; COMINI, 2011). Isso torna o desafio de se medir impactos ainda maior, entretanto, proporciona uma visão mais apurada do resultado efetivo e da importância de determinada ação.

Quando se considerar a necessidade de aumento de escala e se pensar na comparação de negócios sociais distintos, este cuidado é ainda mais relevante. Quando se pensa em escalar determinado negócio com foco no impacto gerado, é fundamental considerar as características do contexto externo, para que a replicabilidade seja assegurada. Para comparar dois negócios, saber qual foi a real influência do negócio no ambiente permite uma análise mais equilibrada e alocação de recursos mais precisa.

Márquez, Reficco e Berger (2010) realizaram a análise de 33 casos de empresas sociais na região Ibero-americana. Tomando como base a análise realizada por esses autores, Portocarrero e Delgado (2010), com a finalidade de sistematizar o conhecimento sobre a geração de valor social, desenvolveram as dimensões relevantes para o desenvolvimento na formulação de avaliações e análises do valor social gerado. O Quadro 3 mostra como cada dimensão, pensada por Portocarrero e Delgado (2010), é exemplificada, e pode-se ter uma 
visão ampla dos aspectos que devem ser levados em consideração durante uma avaliação de resultados de negócios sociais.

\section{Quadro 3 - Principais elementos de geração de valor social}

\begin{tabular}{|c|c|}
\hline Aumento de renda & Acesso a bens e serviços \\
\hline 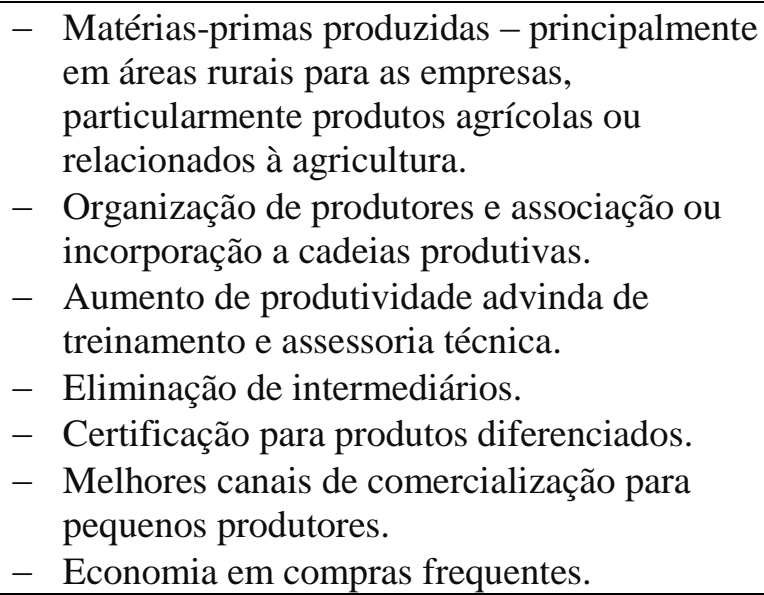 & $\begin{aligned} \text { - } & \text { Redução de preços. } \\
\text { - } & \text { Pagamento fragmentado de bens e serviços e } \\
& \text { sistemas pré-pagos. } \\
\text { - } & \text { Investimentos privados em equipamentos, } \\
& \text { infraestrutura e redes de distribuição. } \\
\text { - } & \text { Acesso flexível a mecanismos de } \\
& \text { empréstimos. } \\
\text { - } & \text { Eliminação de barreiras à educação. }\end{aligned}$ \\
\hline Promoção de cidadania & Desenvolvimento de capital social \\
\hline $\begin{array}{l}\text { - } \text { Reconhecimento e exercício de direitos } \\
\text { básicos (vida, trabalho, entre outros). } \\
\text { - } \text { Defesa de interesses públicos. } \\
\text { - } \text { Maior visibilidade e dignidade para setores } \\
\text { de baixa renda e grupos excluídos. } \\
\text { - } \text { Intermediação de oportunidades de trabalho } \\
\text { para pessoas com deficiência, grupos } \\
\text { excluídos ou indivíduos não qualificados. } \\
\text { - Validação da identidade de indivíduos não } \\
\text { registrados. } \\
\text { - } \\
\text { Acesso físico ao mercado para vender a } \\
\text { produção do setor de baixa renda. } \\
\text { - Consciência ambiental. } \\
\text { - Promoção de bons hábitos de higiene, ordem } \\
\text { e consumo racional. }\end{array}$ & $\begin{array}{l}\text { - } \text { Construção de redes, relacionamentos locais } \\
\text { e fortalecimento de capabilidade. } \\
\text { - } \text { Construção de um sentimento de } \\
\text { pertencimento a uma comunidade. } \\
\text { - } \text { Construção de rede social; confiança, } \\
\text { reciprocidade e desenvolvimento de } \\
\text { cooperação. } \\
\text { - } \\
\text { Maior disponibilidade de recursos próprios e } \\
\text { de terceiros por meio de contatos e } \\
\text { interações. } \\
\text { - } \text { Capacitação do setor de baixa renda para } \\
\text { agilizar e expressar as demandas. } \\
\text { - } \text { Melhoramento da autoestima } \\
\text { - } \text { Associação de interesses individuais. } \\
\text { - } \text { Ligar grupos sociais dispersos a } \\
\text { administrações, empresas, novos mercados } \\
\text { ou clientes locais. }\end{array}$ \\
\hline
\end{tabular}

FONTE: adaptado de Portocarrero e Delgado (2010) por Oliveira Filho, Kiyama e Comini (2011).

O aumento de renda e o acesso a bens e serviços são dimensões mais tangíveis. Essas dimensões são mais evidentes e mais comuns nas avaliações de negócios sociais (PORTOCARRERO; DELGADO, 2010). O aumento de renda é uma dimensão importante para a geração de valor social em projetos focados nas camadas de baixa renda, mas além de gerar receita por meio de empregos estáveis para essa população e consequente aumento de poder de compra e de ampliação das escolhas de consumo, é necessário que se insira estas pessoas nas cadeias produtivas. A inclusão não deve ser focada em torná-los consumidores, 
mas sim em convertê-los em geradores de riqueza, favorecendo as iniciativas que colocam a população de baixa renda no papel de coordenação, cogovernança e liderança das iniciativas.

A dimensão de acesso se restringe aos bens e serviços que são importantes na transposição das barreiras que impedem que necessidades básicas de saúde, educação, direitos civis, moradia, preservação ambiental e geração de renda sejam alcançados. Há diversas barreiras para que as pessoas de baixa renda atendam suas necessidades, como: os altos preços relativos a essa parte da população; problemas de distribuição destes bens em áreas rurais ou periféricas; problemas de acesso a crédito para a compra de bens duráveis; e ineficiências na educação, que geram barreiras para que as decisões sejam mais racionais, a fim de que as competências e a empregabilidade sejam ampliadas para a melhoria na gestão de pequenos negócios e para a melhoria no planejamento financeiro familiar.

As dimensões mais intangíveis e com frequência menor de acompanhamento, promoção de cidadania e desenvolvimento de capital social, são também relevantes para que a inclusão social seja concretizada. A pobreza tem um caráter legal, simbólico e cultural, que impede que determinados direitos sejam exercidos. Portanto, negócios sociais também devem fomentar que o público exerça sua cidadania. Isso pode ser feito através de ações que aumentem a autoestima, fortaleçam o respeito à diversidade e que, principalmente, aumentem a autonomia das pessoas para que se informem, organizem-se e tenham julgamento crítico de leis, direitos e deveres.

O desenvolvimento de capital social é essencial para que os interesses individuais sejam agregados e, dessa forma, os projetos sejam realizados. Quando a população está organizada e conta com uma rede de contatos com outros atores do ecossistema, há sinergias e a possibilidade de que a escala de determinada ação seja alavancada, produzindo resultados mais amplos e consistentes. Além disso, há a possibilidade da criação de novas lideranças e do desenvolvimento de soluções mais duradouras.

A multidimensionalidade e complexidade do conceito de valor social demonstra o desafio que é medir de forma unificada e comparável esse fenômeno. Há que se colocar que a amplitude da diversidade de ações e de objetivos também é outro fator que torna a tarefa de mensuração ainda mais complicada. Com base no trabalho realizado por Portocarrero e Delgado (2010), é possível pensar nos grupos de consequências e resultados que uma iniciativa que busca gerar 
valor social deve se atentar. Essas dimensões devem ser consideradas e balanceadas com a geração de valor econômico devido à relevância da sustentabilidade financeira. Entretanto, essa forma não é única, nem exaustiva e nem se propõe a ser uma ferramenta prática para a mensuração dos resultados.

\subsection{Avaliação de empresas tradicionais}

A divulgação de indicadores, a comparação e a classificação de negócios é uma tarefa amplamente realizada e que é geralmente focada em questões econômicas. Entretanto, em 10 anos surgiram algumas iniciativas para que o mesmo seja feito para avaliar como estas empresas estão em relação ao comprometimento e contribuição para o desenvolvimento sustentável. Ou seja, os sistemas de avaliação são utilizados para classificar o triple bottom line, considerando questões econômicas, sociais e ambientais. (GLOBAL REPORTING INITIATIVE, 2013).

Por uma prática de mercado as empresas, notadamente as de capital aberto, publicam um relatório anual. Nele estão contidos todos os principais fatos ocorridos no ano para aquela organização. Essa publicação, geralmente, tem como foco principal a publicação dos informes financeiros, publicação obrigatória para toda empresa constituída como S.A. (Sociedade Anônima) no Brasil. Entretanto, algumas empresas estão percebendo que esse relatório anual pode ser uma ferramenta de comunicar aos seus stakeholders ações mais amplas que a empresa tem tomado, sejam elas de negócios ou de responsabilidade social corporativa. (GLOBAL REPORTING INITIATIVE, 2013).

Com a intenção de promover a prática de sustentabilidade que contemple questões sociais, econômicas e ambientais, uma organização denominada GRI, Global Reporting Initiative, criou uma série de frameworks e regras para que as empresas reportem de maneira padronizada suas iniciativas (GRI, 2013). Essa organização sem fins lucrativos acredita que, com esse padrão de relatório, é possível identificar mais facilmente as empresas mais comprometidas com as questões de sustentabilidade do negócio. Essa iniciativa vem complementar a visão dos relatórios anuais que no geral só publicam resultados financeiros e questões ligadas somente com a geração de valor econômico, sem nenhuma ligação com as questões sociais e ambientais. (GLOBAL REPORTING INITIATIVE, 2013). 
O International Integrated Reporting Council (2013) é uma iniciativa criada pelo Príncipe de Gales, juntamente com representantes da ONU e especialistas na criação de padrões para a formulação de relatórios. Esta organização agrupa, também, líderes de empresa, investidores, contabilistas, agentes reguladores, acadêmicos, legisladores e agentes da sociedade civil. A organização tem a intenção, assim como o GRI, de criar um framework, aceito internacionalmente, de métricas e de formas de reportar informações sobre estratégia, governança, desempenho e perspectivas de uma maneira clara, concisa e comparável. Desta forma, busca-se gerar uma norma internacional de geração de relatórios únicos que contenham as informações financeiras, de governança, gerenciais e de sustentabilidade integradas.

O Relatório Integrado (ou, no inglês Integrated Report) é a linguagem dos negócios sustentáveis, ou seja, é a forma das empresas comunicarem periodicamente a criação e manutenção no curto, médio e longo prazos do valor gerado. Essas informações devem concentrar os fatores mais relevantes para que os investidores decidam sobre a alocação do capital. A intenção do Relatório Integrado é integrar fatores tangíveis ou financeiros (ex.: Balanço patrimonial, caixa, entre outros) a fatores intangíveis (ex.: gestão de pessoas, gestão de recursos naturais, gestão de capital intelectual, geração de valor social, entre outros) de forma padronizada, assim como são os relatórios financeiros, através de padrões como o Generally Accepted Accounting Principles in the United States, identificada como USGAAP.

Ambas as iniciativas visam um bem em comum: informar stakeholders sobre como empresas integram as questões essenciais para promover o desenvolvimento sustentável de forma comparável e transparente. Inclusive é importante notar a criação desse movimento e a força que este começa a ganhar, tendo reflexos nas bolsas de valores de todo o mundo. Destaca-se nesse quesito o pioneiro Índice Dow Jones de Sustentabilidade (Dow Jones Sustainability Indexes), lançado em 1999, e o ISE da BMF\&BOVESPA, que desde 2005 segmenta as empresas listadas na Bolsa de Valores de São Paulo que se predispõem a divulgar dados e agir sobre as questões sociais e ambientais que o negócio provoca. Ainda não há uma clara ligação destas empresas comprometidas, voluntariamente, com a divulgação de dados socioambientais com o desempenho econômico-financeiro. Mas a adesão a estes programas é cada vez maior. (ARTUSO et al., 2012). 


\subsection{Avaliação de negócios sociais}

Além das formas citadas acima, que são utilizadas por empresas de grande porte e de qualquer segmento, há uma série de ferramentas que são focadas nos negócios sociais. Essas ferramentas são fomentadas por uma grande quantidade de atores, sejam eles empreendedores, público-alvo, instituições governamentais, e, principalmente, por investidores. Os investidores são em muitos casos os atores do ecossistema mais afastados dos resultados e, portanto, os mais carentes por informações credíveis, verídicas e que diferenciem negócios capazes de gerar valor socioambiental dos que não são capazes. As formas mais utilizadas até o momento deste estudo são: IRIS, GIIRS, SROI e algumas certificações.

O IRIS é responsável por agrupar e padronizar indicadores, gerando uma biblioteca de métricas que podem ser utilizadas conforme a necessidade de cada iniciativa. O GIIRS é uma ferramenta de classificação de negócios que utiliza os indicadores do IRIS. Já o SROI é uma metodologia de formulação de indicadores que conta com a participação dos stakeholders. As certificações mencionadas são títulos dados por determinadas organizações que provam seguir determinados padrões reconhecidos como referência.

Existem certificações, como a B-Corporation, que certifica empresas que se propõem a solucionar problemas socioambientais, como as certificações de Fair Trade (comércio justo), para empresas que distribuem a riqueza ao longo da cadeia produtiva e certificações para produtos que seguem padrões de produção, como é o caso dos orgânicos, de procedência do uso de florestas, entre outros. Cada uma dessas tentativas de produzir algo mais replicável com resultados mais padronizados e comparáveis possui suas especificidades, pontos fortes e pontos fracos. O importante é que são sistemas de avaliação que já estão em uso por grandes empresas de investimento de impacto.

Investimento de impacto, de acordo com a Global Impact Investing Network (2012), é o investimento que objetiva solucionar desafios sociais e ambientais gerando lucro financeiro. O retorno pode ser apenas do montante investido, mas também de taxas de retorno competitivas ao mercado de investimento. Investidores de impacto buscam a alocação para o capital que maximize o retorno socioambiental e amplie o poder positivo das empresas. 
O IRIS foi criado com o objetivo de ser uma linguagem comum de relatórios de impacto. Criado em 2008 pela The Rockefeller Foundation, Acumen Fund e B Lab, seu objetivo é reduzir a fragmentação das inúmeras métricas criadas pelas organizações que identificaram que a análise financeira não era suficiente para realizar investimentos voltados à geração de impacto socioambiental. Com a consolidação de métricas, talvez seja possível tornar a avaliação de impacto mais eficiente e menos custosa, além de simplificar a análise de investidores e empresas, por possibilitar comparações e benchmarking (INTERNATIONAL INTEGRATED REPORTING COUNCIL, 2012).

Essa ferramenta de avaliação do impacto socioambiental tem como objetivo: atender as necessidades de investidores de fundos e investidores diretos, uma vez que padroniza os indicadores que podem ser aplicados em diferentes setores e diferentes regiões do globo, possibilitando comparações; para empresas que estão em busca de investimentos, levando-se em conta que os padrões podem ser utilizados em diferentes tipos de organizações e por facilitar o diálogo com investidores; e para organizações de apoio que auxiliam organizações de diversos setores e atividades, por apresentar um framework único de avaliação.

O framework desenvolvido propõe que as métricas escolhidas coincidam com os objetivos de cada uma das organizações, dentro de seis categorias, sendo que, com exceção da descrição organizacional, cada uma das categorias deve ser realizada para cada produto ou serviço oferecido. São elas: a) Descrição organizacional: métricas com foco na missão organizacional, no modelo de operação e no local; b) Descrição do produto: métricas que descrevem os produtos e os mercados alvos; c) Desempenho financeiro: métricas financeiras usuais; d) Impacto operacional: métricas para as políticas adotadas pelas organizações, para funcionários e para o desempenho financeiro; e) Impacto do produto: métricas para o desempenho e o alcance dos produtos; f) Glossário: definições e termos que são referências das métricas.

O IRIS também apresenta métricas específicas para cada setor de atuação: intersetorial; agricultura; educação; energia; meio ambiente; serviços financeiros; saúde; moradia; e água. Considerando todas estas dimensões, o IRIS apresenta 446 indicadores que podem ser selecionados.

Integrado ao IRIS, foi desenvolvido o GIIRS, um sistema compreensivo e transparente para avaliar o impacto social e ambiental de empresas e de fundos de investimento com a 
metodologia análoga ao ranking de investimento da Morningstar e da análise financeira de risco da Capital IQ (empresa provedora de informações financeiras da Standart \& Poor's). Esse produto de classificação visa fornecer informação de fácil entendimento, comparável e transparente para empresas que querem investir em empresas que estão gerando impacto socioambiental positivo (GLOBAL IMPACT INVESTING RATING SYSTEM, 2012). O GIIRS é uma terceira parte independente da organização sem fins lucrativos B Lab, que pretende mudar o comportamento do investidor e fomentar o investimento de impacto.

O GIIRS provém classificação de impacto de empresas e fundos, além de análises para que o impacto gerado possa ser comparado. As empresas são classificadas em 15 subcategorias e por indicadores-chave de cada setor, geografia, tamanho da empresa e missão social. Já os fundos de impacto são classificados pelo portfólio, incluindo as subcategorias de empresas, os indicadores importantes para o fundo e suas práticas de gestão. O sistema de classificação pode ser utilizado por gestores de fundos para a captação de investidores focados em causas sociais e ambientais, além de auxiliar investidores institucionais a conduzirem due dilligences, a rastrear e potencializar o impacto socioambiental, além de prover ferramentas analíticas para melhorar o valor adicionado ao ecossistema.

Outra forma de se realizar a avaliação de impacto social é através do SROI. Esta abordagem é utilizada para entender e gerenciar os outcomes do valor social, econômico e ambiental gerados por uma atividade, baseados em alguns princípios propostos por este framework (THE SROI NETWORK, 2012). Os princípios são: a) Envolvimento de stakeholders; b) Foco na mudança; c) Valorizar o que é foco; d) Somente incluir o que é importante; e) Ser comparável, para ser credível; f) Ser transparente; g) Acompanhar o resultado;

Esses princípios evidenciam algumas diferenças das outras formas de avaliar o valor social das alternativas citadas. O foco do SROI é colocar o valor das pessoas geralmente excluídas do mercado, no mesmo patamar, influenciando as decisões de alocação de recursos. O SROI não contém somente números, contém uma "história", que deve ser capaz de mostrar como o valor social é criado. Para isso a análise do SROI envolve seis passos:

1. Estabelecer escopo e identificar stakeholders chaves; 
2. Mapear outcomes, utilizando a visão dos stakeholders escolhidos e identificando a relação entre inputs, outputs e incomes;

3. Evidenciar outcomes e valorá-los: determinar valores financeiros para os mesmos;

4. Estabelecer impactos: identificar aspectos de mudanças e excluir o que teria sido modificado sem a ação estudada;

\section{Calcular o SROI;}

6. Divulgar, usar e integrar: compartilhar os resultados com stakeholders incorporando os resultados com a verificação dos dados.

O SROI se propõe a ser uma ferramenta de melhoria dos serviços, pois cria uma base comum e analítica para basear decisões e discussões; auxilia na sustentabilidade das organizações, gerando uma base confiável de resultados e facilitando a entrada de capital; é comparável entre diferentes organizações, facilitando o trabalho de investidores e stakeholders que desejam comparar a efetividade de seus negócios.

É necessário pontuar que há outros sistemas de avaliação de negócios que se propõe a gerar valor social, como pode ser visto no Quadro 4. Entretanto, essas formas são menos abrangentes, não consideram algumas dimensões ou têm seu uso ainda limitado a determinadas regiões. As ferramentas citadas anteriormente são as mais usuais no mercado brasileiro e por isso apresentam sua descrição neste trabalho. 
Quadro 4 - Abordagens de mensuração de impacto

\begin{tabular}{|c|c|c|c|}
\hline \multirow{2}{*}{ Abordagens } & \multicolumn{3}{|c|}{ Sistemas } \\
\hline & Classificação & Avaliação & Gestão \\
\hline$B$ ratings system & $\mathrm{X}$ & $\mathrm{X}$ & - \\
\hline Balanced scorecard modified to include impact & - & - & $\mathrm{X}$ \\
\hline CHAT (charity analysis tool) & $\mathrm{X}$ & $\mathrm{X}$ & - \\
\hline Compass assessment for investors & $\mathrm{X}$ & $\mathrm{X}$ & - \\
\hline Dalberg approach & $\mathrm{X}$ & $\mathrm{X}$ & - \\
\hline DOTS (development outcome tracking system) & - & $\mathrm{X}$ & - \\
\hline Ecological footprint & $\mathrm{X}$ & $\mathrm{X}$ & - \\
\hline EPRS (environmental performance reporting system) & - & $\mathrm{X}$ & - \\
\hline Fair trade certification & $\mathrm{X}$ & - & - \\
\hline HIP (human impact + profit) framework & $\mathrm{X}$ & $\mathrm{X}$ & - \\
\hline LEED (leadership in energy and environmental design) & $\mathrm{X}$ & - & - \\
\hline Movement above the us $\$ 1$ a day threshold project & $\mathrm{X}$ & - & - \\
\hline PDMS (portfolio data management system) & - & $\mathrm{X}$ & $\mathrm{X}$ \\
\hline PPI (progress out of poverty index) & - & $\mathrm{X}$ & - \\
\hline PROI (political return on investment) & $\mathrm{X}$ & $\mathrm{X}$ & - \\
\hline RISE (real indicators of success in employment) and oasis & - & $\mathrm{X}$ & - \\
\hline SIA (social impact assessment) & - & $\mathrm{X}$ & - \\
\hline Social rating & $\mathrm{X}$ & $\mathrm{X}$ & - \\
\hline Trucost & - & $\mathrm{X}$ & $\mathrm{X}$ \\
\hline
\end{tabular}

FONTE: adaptado de Olsen e Galimidi (2008, p. 19).

\subsection{Diferentes óticas para a avaliação de valor social}

A escolha do sistema de mensuração de valor social gerado depende da necessidade e da ótica de quem as escolhe. Para conseguir realizar a discussão e a escolha de um destes sistemas, é necessário levar em conta as necessidades dos diferentes atores envolvidos. Este trabalho seguirá a divisão proposta de Oliveira Filho, Kiyama e Comini (2011): beneficiário, empreendedor e investidores, por utilizarem uma forma simples de caracterizar diferentes interesses.

O beneficiário tem interesse de cliente; o empreendedor tem objetivo de rentabilidade e foco na gestão; já os investidores utilizam os indicadores para tomar a decisão em quem vão investir. Essas diferenças serão determinantes para conseguir entender as diferenças de necessidades e alguns conflitos nas escolhas de métricas. 


\subsubsection{Beneficiários}

Os beneficiários são contemplados na visão de valor social apresentada por Portocarrero e Delgado (2010) e na visão de Calil (2012). Na visão de Portocarrero e Delgado (2010), a mudança das condições de vida dos beneficiários é o reflexo que deve ser medido para se identificar geração de valor social. Dessa forma, os beneficiários em alguns casos não precisam da divulgação de indicadores, pois já sentem os resultados em suas atividades do dia a dia.

Há medidas que são reconhecidas de forma mais simples pelos beneficiários, como o impacto na renda e a possibilidade de acesso a produtos e serviços; em contrapartida, há resultados que serão sentidos com menor intensidade ou por um número menor de beneficiários, como é o caso da construção da cidadania e do desenvolvimento do capital social. Dessa forma, na visão exclusiva dos beneficiários, a importância de métricas que mostrem os efeitos do primeiro grupo de dimensões é menos necessária que aquelas que demonstrem os resultados do segundo bloco de dimensões. Questões mais abstratas devem ser tangibilizadas para que os beneficiários valorizem as ações e também participem dos programas oferecidos a eles. Vale lembrar que quando o público beneficiário é o cliente, este deve ser comunicado de maneira clara dos benefícios que se tem ao "adquirir" determinado produto ou serviço.

Uma abordagem mais processual desta questão é o envolvimento dos beneficiários na escolha e formulação dos indicadores (CALIL, 2012; THE SROI NETWORK, 2012). Primeiramente, para que se tenha maior segurança de que os indicadores reflitam de forma concreta o objetivo do projeto, mas que também produzam um efeito de mobilização e aprendizado (CALIL, 2012). A mobilização é importante tanto para a criação de escala quanto pela valorização da evolução nos casos em que os resultados serão percebidos mais no longo prazo. O aprendizado gerado, quando há participação efetiva dos beneficiários, gera mudança de conduta que pode influenciar os resultados do projeto, seja por conta da comunicação dos objetivos e limitações, seja devido ao entendimento profundo dos efeitos pelos beneficiários.

Os beneficiários são os clientes da geração de valor social. São eles que determinam se o negócio gera ou não valor. Portanto, devem ser o foco da ação de empresas sociais, e são neles que os impactos sobre os fatores que possibilitam a liberdade individual de Sen (2010) devem ser medidos. Entretanto, algumas vezes os beneficiários buscam soluções imediatas 
para os problemas em que vivem e os indicadores podem ajudar a demonstrar que os resultados estão sendo construídos e estão sendo entregues, criando uma relação de parceria com o beneficiário e outras partes interessadas nos resultados. Dessa forma, o valor social pode ser maximizado e o objetivo da organização alcançado de maneira mais rápida.

\subsubsection{Empreendedor}

O foco do empreendedor deve ser no objetivo e resultados almejados. Para garantir aderência das decisões a este propósito traçado, usam-se os indicadores. Outro desafio é conseguir balancear de maneira eficiente os indicadores financeiros e os indicadores socioambientais. Portanto, os indicadores têm papel fundamental para este ator, que é responsável pela gestão e escolha dos indicadores. O empreendedor deve entender também o papel dos indicadores no relacionamento com outros atores do ecossistema, como é o caso dos beneficiários e dos investidores. O papel dele é definir as métricas que o manterão no rumo proposto e também as métricas que vão envolver público-alvo e investidores dentro de seu objetivo (CALIL, 2012).

Os frameworks mostrados, como o IRIS, GIIRS e SROI, objetivam auxiliar o empreendedor a desenvolver um painel de controle, entretanto, a variabilidade de situações distancia o uso de uma forma simples de entender as métricas que realmente refletem se o objetivo dele está perto ou longe dos resultados alcançados. Uma das formas recomendadas pelos próprios sistemas de formulação de indicadores é a utilização deles em conjunto. Pode-se utilizar o SROI para identificar quais métricas são importantes para os stakeholders (entre eles beneficiários e investidores) envolvidos e o IRIS para que as métricas escolhidas estejam dentro de padrões de construção e de comparabilidade estabelecidos.

O desafio de empreendedor é conseguir criar um sistema de informações que consiga estimular a interação no ecossistema, que possibilite a gestão e o aumento da eficiência dos resultados e que não tire o foco da ação dos negócios para a gestão e divulgação de métricas. Há uma grande crítica realizada pelos empreendedores que exigem que o sistema de governança e de gestão de indicadores seja modificado para atender aos anseios de investidores. Contudo, isso é uma questão que deve ser analisada caso a caso. 


\subsubsection{Investidores}

Os investidores de impacto também seguem a teoria econômica da busca pela maximização de retornos, sejam eles financeiros ou socioambientais, e convivem com a restrição das limitações de recursos. Portanto, realizam o trabalho de seleção de empresas a serem investidas com muita cautela. Para realizar a tarefa de alocação, os investidores precisam de métricas comparáveis, credíveis e que tragam informações relevantes sobre a geração de valor, o que os aproxima das regras de demonstrações financeiras (OLIVEIRA FILHO, KIYAMA; COMINI, 2011).

Para que as métricas sejam comparáveis e facilitem o processo de comparação entre iniciativas de setores diferentes, de lugares diferentes e com propósitos diferentes, os investidores abrem mão de flexibilidade em relação às métricas e preferem negócios que já apresentem as métricas padronizadas, como é o caso do IRIS. Além do uso desse framework, os investidores contam com as classificações realizadas pelo GIIRS, que facilita a decisão da escolha de negócios que receberam investimento e que ajuda os gestores de fundos a embasarem suas justificativas em razões analíticas.

Entretanto, esses indicadores padronizados devem ter sua forma de contabilização e sua forma de divulgação também dentro de determinados padrões de qualidade, transparência e de rastreabilidade, para que se tenha a maior segurança possível da veracidade dos dados. Essa necessidade provoca, em alguns casos, uma série de atritos com os empreendedores e necessidades de indicadores diferentes dos necessários para os beneficiários e outros stakeholders. Esta seria outra razão pela qual um sistema de avaliação único seja validado e utilizado. Mas isso nem sempre é possível, e o framework utilizado, assim como a formulação dos indicadores, torna-se mais uma fonte de negociações entre os membros do ecossistema.

\subsection{Desafios}

A geração de valor social é uma dimensão mais complexa de ser mensurada que a geração de valor econômico, pois é pautada por indicadores qualitativos, e ainda não conta com um padrão amplamente aceito. Essas barreiras dificultam a adaptação dos que estão acostumados com os sistemas convencionais de avaliação e exigem um exercício interativo de proposição, 
críticas e ajustes para que as ferramentas evoluam e para que exista algum tipo de padronização que seja aceito e que permeie os agentes que as utilizam.

Com o desafio de encontrar formas eficientes de medir os benefícios gerados por negócios sociais, o próximo capítulo mostra problemas relevantes em uma das áreas em que os sistemas público e privado ainda não apresentam soluções suficientes: o sistema de saúde brasileiro. 


\title{
4 CONTEXTO DE SAÚDE
}

\subsection{Saúde no mundo}

A Organização Mundial da Saúde (2010, p. xi) dedica seu último Relatório Mundial da Saúde à discussão sobre alternativas de financiamento para universalização do acesso à saúde no mundo todo:

\begin{abstract}
A promoção e proteção da saúde são essenciais para o bem-estar do homem e para o desenvolvimento econômico e social sustentável. Isto foi reconhecido há mais de 30 anos pelos signatários da Declaração de Alma-Ata, que assinalaram que a Saúde para Todos contribuiria tanto para melhor qualidade de vida como também para a paz e segurança global.
\end{abstract}

O Relatório define como cobertura universal à saúde os sistemas que conseguem fazer com que as pessoas tenham acesso a serviços médicos sem sacrifícios financeiros para pagá-los. Essa definição foi registrada na Resolução 58.33 da Assembleia Mundial da Saúde de 2005. Para que isso aconteça, três barreiras devem ser superadas: disponibilidade de recursos, dependência excessiva de pagamentos diretos no momento em que se precisa de cuidados e o uso ineficiente e desigual de recursos.

As soluções propostas atuam nas dimensões que devem ser trabalhadas para a cobertura universal, conforme sintetizado na Figura 2. As soluções são altamente dependentes do sistema de financiamento. 


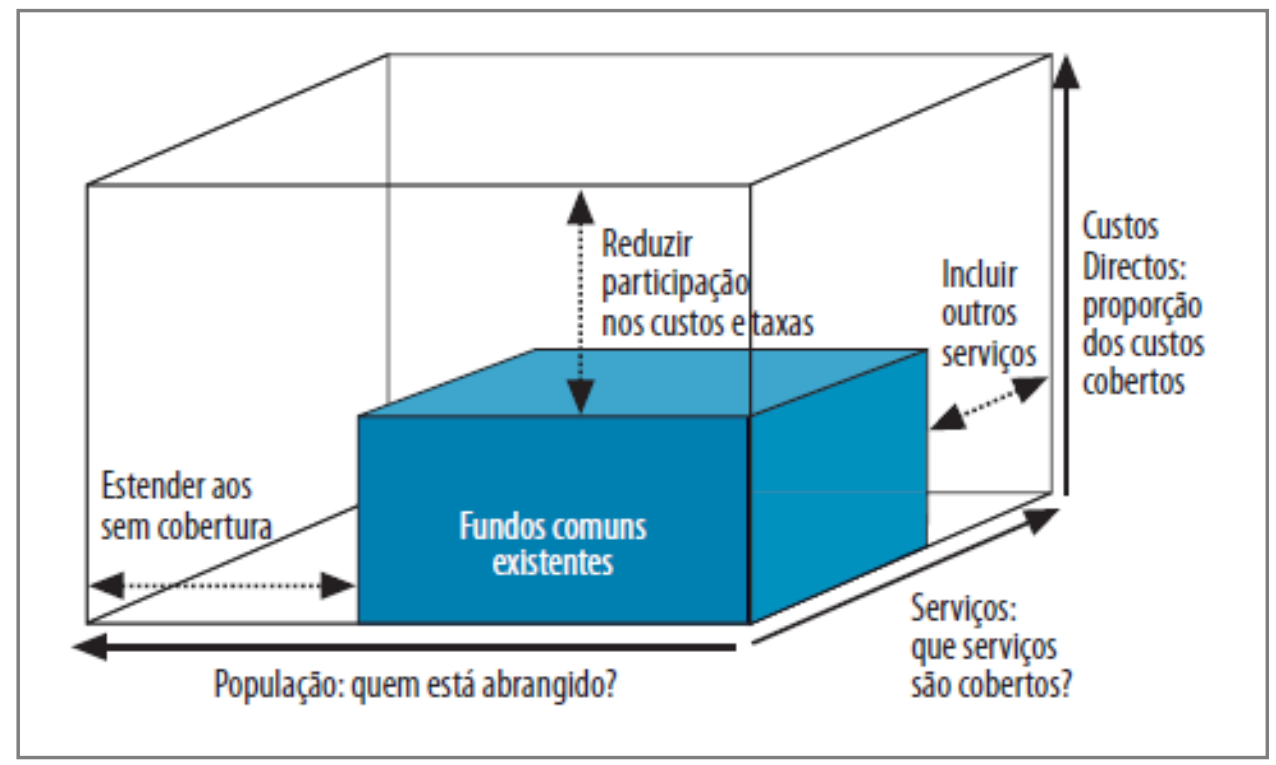

Figura 2: Três dimensões a considerar na aproximação à cobertura universal FONTE: Organização Mundial da Saúde (2010, p. 14).

Há, entretanto, outras barreiras que dificultam o acesso aos serviços de saúde ou à continuidade em caso de um tratamento mais extenso. Uma delas é a distância dos pontos de atendimento e o outro é a perda de rendimento durante o tratamento. Segundo estimativa conservadora, há uma perda de $20 \%$ a $40 \%$ dos recursos gastos em saúde por conta da ineficiência (ORGANIZAÇÃO MUNDIAL DA SAÚDE, 2010).

De acordo com o relatório da Faculdade de Medicina da Universidade de São Paulo (2007), os modelos de financiamento de saúde podem ser divididos em quatro diferentes formas, conforme o Quadro 5. 
Quadro 5 - Modelos de financiamento de saúde

\begin{tabular}{|c|c|c|c|c|}
\hline \multirow{2}{*}{$\begin{array}{c}\text { Parcelas da } \\
\text { População }\end{array}$} & Assistencialista & Previdencialista & $\begin{array}{c}\text { Universalista } \\
\text { Unificado }\end{array}$ & $\begin{array}{c}\text { Universalista } \\
\text { Diversificado }\end{array}$ \\
\cline { 2 - 5 } & Fontes fiscais & $\begin{array}{c}\text { Sem recursos } \\
\text { definidos } \\
\text { renda }\end{array}$ & $\begin{array}{c}\text { Fontes fiscais e } \\
\text { contribuições } \\
\text { sociais gerais }\end{array}$ & $\begin{array}{c}\text { Fontes fiscais e } \\
\text { contribuições } \\
\text { sociais gerais }\end{array}$ \\
\hline $\begin{array}{c}\text { Trabalhadores } \\
\text { formais e } \\
\text { camadas médias }\end{array}$ & $\begin{array}{c}\text { Pagamento direto } \\
\text { pelos serviços }\end{array}$ & $\begin{array}{c}\text { Contribuições } \\
\text { sociais sobre folha } \\
\text { de salários } \\
\text { (compulsórias) }\end{array}$ & $\begin{array}{c}\text { Fontes fiscais e } \\
\text { contribuições } \\
\text { sociais gerais }\end{array}$ & $\begin{array}{c}\text { Contribuições } \\
\text { sociais sobre folha } \\
\text { de salários } \\
\text { (compulsórias) }\end{array}$ \\
\hline $\begin{array}{c}\text { Camadas de alta } \\
\text { renda }\end{array}$ & $\begin{array}{c}\text { Pagamento direto } \\
\text { pelos serviços }\end{array}$ & $\begin{array}{c}\text { Pagamento direto } \\
\text { pelos serviços }\end{array}$ & $\begin{array}{c}\text { Fontes fiscais e } \\
\text { contribuições } \\
\text { sociais gerais }\end{array}$ & $\begin{array}{c}\text { Pagamento direto } \\
\text { pelos serviços, } \\
\text { planos privados } \\
\text { especiais } \\
\text { (voluntário) }\end{array}$ \\
\hline
\end{tabular}

FONTE: adaptado de Faculdade de Medicina da Universidade de São Paulo (2007).

Além de padrões de financiamento, os sistemas de saúde se dividem por esferas de atendimento, que variam conforme o país. Os níveis dependem da tecnologia material incorporada (máquinas e equipamentos de diagnóstico e de terapêutica), da capacitação de pessoal (custo social necessário para formação) e perfil de morbidade da população alvo.

O nível primário responde à grande maioria de casos solucionados (estima-se de $85 \%$ a 90\%) e depende de equipamentos de menor grau de incorporação tecnológica (tais como aparelhos de raios-X, eletrocardiógrafo) e a capacitação menor, mais abrangente para atuação com ênfase familiar.

O nível secundário depende de equipamentos mais sofisticados (tais como raios-X com alguma sofisticação, ecocardiógrafo, ultrassom, aparelhos de endoscopia), necessita de atendimento especializado pelas áreas de formação como oftalmologia, pediatria e outros, e deve solucionar casos que não puderem ser resolvidos no nível primário.

O nível terciário recebe a população que não teve atendimento no nível secundário e, portanto, depende de equipamentos de alta tecnologia (tais como ressonância magnética, PET Scan) e de profissionais superespecializados como neurocirurgiões, oncologistas, entre outras.

Conforme os indicadores utilizados pela World Health Organization (2012), o Brasil ainda apresenta índices abaixo da média do continente americano, mas também apresenta bons 
índices, como no caso da cobertura oferecida para imunização de crianças com menos de um ano e na cobertura de tratamentos como HIV e tuberculose. O mesmo documento mostra que apesar de haver aumento da porcentagem do PIB utilizado para a saúde - de 7,2\% em 2000 para $8,8 \%$ em 2009, o país ainda apresenta uma média muito inferior a da média de 14,4\% da região das Américas. Outro dado importante aponta que $76 \%$ do dinheiro utilizado para a saúde em 2009 foi proveniente do governo. O que mostra uma dependência grande do Estado no sistema de saúde brasileiro.

\subsection{Saúde no Brasil}

O sistema de saúde brasileiro é de fato calcado na participação do Estado. Denominado SUS, Sistema Único de Saúde, este foi aprovado em 1988 na Constituição Federal, e foi implementado pela Lei Orgânica da Saúde em 1990. Tem como princípios: a universalidade no acesso, a igualdade no tratamento e a equidade na distribuição dos recursos. Apresenta as diretrizes: descentralização (transferência de serviços da esfera federal para a estadual e destes para a municipal), pelo atendimento integral (atividades assistenciais e preventivas) e pela participação da comunidade (por meio das conferências e conselhos de saúde), esta consagrada em nosso meio como controle social (FACULDADE DE MEDICINA DA UNIVERSIDADE DE SÃO PAULO, 2007). Entretanto, apesar da forte presença do Estado em alguns tipos de programas, a "[...] qualidade da assistência difere segundo os diferentes estratos sociais [...]” (BERTOLUZZI; GRECO, 1996, p. 395). Outro problema apontado pelos autores é o sucateamento do setor público, que “[...] expulsa a clientela deste setor para o privado [...]" (p. 395).

O SUS é um dos maiores sistemas públicos de saúde do mundo, com 190 milhões de beneficiários, sendo que cerca de $80 \%$ desse montante depende exclusivamente desse sistema para ter acesso a serviços de saúde. O SUS possui uma rede de 6,1 mil hospitais credenciados, 45 mil unidades de atenção primária e 30,3 mil Equipes de Saúde da Família, além de realizar 2,8 bilhões de procedimentos ambulatoriais anuais, 19 mil transplantes, 236 mil cirurgias cardíacas, 9,7 milhões de procedimentos de quimioterapia e radioterapia e 11 milhões de internações. Também faz parte do SUS a criação do Serviço de Atendimento Móvel de Urgência, Políticas Nacionais de Atenção Integral à Saúde da Mulher, de Humanização do 
SUS e de Saúde do Trabalhador, além de programas de vacinação em massa de crianças e idosos em todo o país e realização de transplantes pela rede pública (BRASIL, 2010).

Para que se atinja o número elevado de atendimentos, é necessário entender o modelo de financiamento escolhido pelo sistema utilizado no país, que se aproxima do Modelo Universalista Unificado, já detalhado no Quadro 5. Portanto, o sistema de saúde escolhido pelo Brasil visa ao atendimento através dos recursos do Estado para toda a população da mesma forma, o que implica uma necessidade muito grande de recursos disponíveis e aplicados (FACULDADE DE MEDICINA DA UNIVERSIDADE DE SÃO PAULO, 2007). O financiamento do SUS é baseado em um percentual definido sobre a arrecadação de estados, um percentual diferente para municípios, e a contribuição da União com um percentual corrigido conforme o PIB.

O SUS também conta com a modalidade de prestação de serviços para o setor público, em que agentes privados realizam serviços e são remunerados pelo governo. Esses pagamentos seguem, normalmente, uma tabela de pagamentos por tipo de procedimento efetuado. Este fato, apesar de promover o aumento de atendimentos sem custos com infraestrutura por parte do governo, também gera distorções pelo fato de os provedores de serviço desestimularem o uso de suas instalações para serviços em que o valor de pagamento é menor, e estimularem os procedimentos mais bem remunerados (TORRES, 2011).

Além do SUS, o sistema de saúde brasileiro conta com o Sistema de Assistência Médica. Esse sistema é formado por empresas reguladas pela Agência Nacional de Saúde Suplementar desde 2000. A Agência é vinculada ao Ministério da Saúde e tem como missão “[...] promover a defesa do interesse público na assistência suplementar à saúde, regular as operadoras setoriais e contribuir para o desenvolvimento das ações de saúde no país [...]" (FACULDADE DE MEDICINA DA UNIVERSIDADE DE SÃO PAULO, 2007, p. 21). O Sistema de Assistência Médica é formado por modalidade lucrativa, ou seja, pelos planos de saúde, seguro saúde e planos odontológicos, e por modalidade não lucrativa, que inclui a autogestão, as cooperativas médicas, as cooperativas odontológicas e os planos de entidades filantrópicas. Essa divisão, no entanto, é apenas formal, posto que as empresas não lucrativas seguem os procedimentos operacionais das lucrativas. 
O Quadro 6 mostra de maneira sintética os tipos de serviços, os provedores, as modalidades de financiamento e a importância do setor privado para garantir o acesso de famílias da base da pirâmide, para as políticas de saúde adotadas pelo governo brasileiro.

Quadro 6 - Modelo de serviços de saúde no Brasil

\begin{tabular}{|c|c|c|c|}
\hline \multicolumn{2}{|c|}{ Tipo } & \multicolumn{2}{|c|}{ Setor privado } \\
\hline $\begin{array}{c}\text { Serviço } \\
\begin{array}{c}\text { Baixa } \\
\text { (nível primário) }\end{array}\end{array}$ & $\begin{array}{c}\text { Provedor } \\
\text { predominante }\end{array}$ & $\begin{array}{c}\text { Modalidades principais de } \\
\text { participação }\end{array}$ & $\begin{array}{c}\text { Importância para o acesso de } \\
\text { famílias da base da pirâmide }\end{array}$ \\
\hline $\begin{array}{c}\text { Média } \\
\text { complexidade } \\
\text { (nível secundário) }\end{array}$ & $\begin{array}{c}\text { Estados e setor } \\
\text { privado }\end{array}$ & $\begin{array}{c}\text { Oferta direta e prestação de } \\
\text { serviços ao setor público }\end{array}$ & Maixa direta ao consumidor \\
\hline $\begin{array}{c}\text { Alta } \\
\text { complexidade } \\
\text { (nível terciário) }\end{array}$ & Setor privado & $\begin{array}{c}\text { Oferta direta e prestação de } \\
\text { serviços ao setor público }\end{array}$ & Média \\
\hline $\begin{array}{c}\text { Remédios } \\
\text { Setor privado }\end{array}$ & $\begin{array}{c}\text { Oferta direta e venda para o setor } \\
\text { público, inclusive no âmbito do } \\
\text { programa Farmácia Popular }\end{array}$ & Elevada \\
\hline
\end{tabular}

FONTE: adaptado de Torres (2011).

Em um estudo solicitado pela Potencia Ventures, realizado por uma empresa especializada em estudos sobre serviços públicos e saúde, a Prospectiva, foram analisados alguns aspectos do sistema de saúde atual: prevenção, atenção básica, atenção de média complexidade, atenção de média complexidade e variáveis transversais a estes segmentos, como: Seguros e planos de saúde, telemedicina, eHealth, ${ }^{2}$ Gestão e automação, acesso à informação e acompanhamento de doenças crônicas (POTENCIA VENTURES; PROSPECTIVA, 2012).

As principais deficiências encontradas no estudo, em relação ao SUS, são prevenção, saúde e higiene bucal, controle de epidemias, encaminhamentos a médicos especialistas e filas de espera para atendimento e cirurgias. Além disso, o público que mais demanda atenção são crianças e adultos com mais de 50 anos. As doenças crônicas são a principal causa de morte (POTENCIA VENTURES; PROSPECTIVA, 2012).

Há, porém, outros problemas identificados por Piola et al. (2009), como a busca de uma solução para o financiamento, a garantia de atendimento, a judicialização e a relação entre o SUS e o sistema de Saúde Complementar.

\footnotetext{
${ }^{2} \mathrm{O}$ eHealth é um termo utilizado para a prática da medicina com o suporte da internet e/ou processo eletrônicos de comunicação.
} 
Conforme dito anteriormente, a questão de financiamento é um desafio para todos os países do mundo, notadamente para os países com menor nível de rendimentos (WORLD HEALTH ORGANIZATION, 2010). Para o Brasil este problema não é diferente. A dependência dos recursos estatais limita a capacidade de oferta e organização de uma rede que gere acesso universal. Dessa forma, as famílias se veem obrigadas a destinar recursos para a saúde. O orçamento alocado em serviços de saúde chega a atingir $7,1 \%$ do rendimento total das famílias mais pobres. Esse fato reforça a questão do custo da pobreza, uma vez que para famílias mais ricas há o consumo de 4,5\% da renda. Nas famílias de menor renda os gastos com medicamentos representam 80\% das despesas de saúde (PIOLA et al., 2009).

O SUS tem como princípio a integralidade, ou seja, tem a obrigação de atender a todas as necessidades dos cidadãos. Por conta desse preceito e do artigo 196 da Constituição Federal de 1988, que prevê a saúde como direito de todos e dever do Estado, muitos mandatos judiciais estão sendo pedidos para o acesso a determinados medicamentos ou procedimentos. Essa chamada, "judicialização da saúde", além de aumentar a demanda de atendimento do judiciário, coloca em pauta a discussão em relação aos limites do direito à saúde (PIOLA et al., 2009).

A interação entre o SUS e o Sistema Suplementar também gera desafios complexos. Esse problema se deve ao fato de que o usuário do Sistema Suplementar pode utilizar o atendimento rápido a especialistas e exames, e ainda recorrer ao SUS em casos de atendimentos mais complexos e caros, como hemodiálises e transplantes. No entanto, os usuários do SUS não podem contar com especialistas e exames (nível secundário). Essa situação de um lado mostra efeitos de iniquidade social e má distribuição de recursos públicos, mas por outro lado garante bom atendimento para o nível terciário (PIOLA et al., 2009).

Além desse impasse foram observados alguns problemas de regulação para o desenvolvimento de segmentos importantes que poderiam ajudar na solução destes problemas, como é o caso da falta de regulação sobre microsseguros, telemedicina, eHealth e mHealth. ${ }^{3}$ Além disso, para conseguir medicamentos e exames em unidades do SUS é

\footnotetext{
${ }^{3} \mathrm{O}$ mHealth é um termo utilizado para a prática da medicina com o suporte de dispositivos móveis (celulares, tablets, entre outros).
} 
necessário ter a autorização dos médicos do sistema público de saúde, causando mais filas e dificuldades para o sistema (POTENCIA VENTURES; PROSPECTIVA, 2012).

Somam-se a isso as restrições provocadas pelos Conselhos de Medicina (regionais e federal), que impedem algumas práticas que poderiam ajudar na escalabilidade de certos tratamentos e soluções que são utilizadas em outros países. E também à tradicional falta de eficiência e velocidade do governo para se adaptar a mudanças e inovações.

O sistema de saúde brasileiro atual, conforme mostrado, não tem capacidade de atender a toda demanda, o que causa longas filas de espera para atendimentos, o que em muitos casos geram prejuízos aos tratamentos. No entanto, isso pode ser visto como uma possibilidade de atuação do setor privado. Não nos moldes vistos na maioria dos casos, mas com uma visão de geração de valor social e econômico, ou seja, uma oportunidade de mercado para os empreendedores de negócios sociais (TORRES, 2011). Essa atuação de entidades privadas e com soluções inovadoras cria discussões e embates com os órgãos regulatórios, que precisam de formas confiáveis de mensuração de impacto social que identifique as iniciativas que estão trazendo benefícios ao sistema daquelas que prejudicam o acesso da camada mais pobre da população. Essa utilização de métricas é um dos propósitos da pesquisa a ser realizada. 


\section{ASPECTOS METODOLÓGICOS}

A dificuldade na elaboração e na escolha de indicadores é gerada por uma série de barreiras, sejam elas metodológicas, de transparência, de diversidade de objetivos, de necessidades divergentes entre os membros do ecossistema ou mesmo pela localização geográfica. Por estas razões, este estudo levanta algumas perguntas:

a) Os negócios sociais realizam gestão de indicadores? Quais, como e por qual razão? (Quem é o principal usuário de indicadores? Qual a razão mais importante para se ter indicadores?)

b) De que forma os indicadores são utilizados para gerar valor pelos novos negócios sociais?

c) Quais as dificuldades na utilização dos indicadores? Os indicadores existentes são aplicáveis?

d) Quais ferramentas de indicadores são utilizadas por cada negócio?

\subsection{Objetivos do trabalho}

\subsubsection{Objetivo geral}

Identificar e comparar como a geração de valor social é avaliada pelos negócios sociais focados em saúde no Brasil, pelos próprios empreendedores e pelas organizações de apoio desse ecossistema. 
a) Identificar principais ferramentas, metodologias $\mathrm{e}$ frameworks utilizados por empreendedores, beneficiários e investidores na mensuração de valor social gerado por iniciativas mercadológicas com propósito socioambiental;

b) Identificar principais desafios na mensuração, na formulação, no acompanhamento e na comparação de indicadores de mensuração de valor social;

c) Descrever os benefícios trazidos ao ecossistema pelos indicadores utilizados;

d) Identificar as barreiras e oportunidades para o uso de indicadores como ferramenta estratégica.

\subsection{Tipo de pesquisa}

O tema negócios sociais ainda é pouco explorado, apesar do aumento rápido de publicações acadêmicas a este respeito nos últimos anos. Os negócios sociais, porém, estão em estágio inicial: $52 \%$ das empresas mapeadas surgiram após 2005 (FUNDAÇÃO AVINA; POTENCIA VENTURES; ASPEN NETWORK OF DEVELOPMENT ENTREPRENEURS POLO BRASIL, 2011). Devido a essa característica, pela formulação da pergunta e pela escolha de foco desta pesquisa, optou-se por uma pesquisa qualitativa exploratória com estudo de casos múltiplos.

Uma pesquisa é caracterizada como exploratória devido a sua natureza de investigação em determinada área na qual o conhecimento acumulado ainda é incipiente (VERGARA, 2005). Como o resultado esperado do trabalho é pautado pelo interesse em levantar formas de avaliação na geração de valor social e suas implicações, a abordagem exploratória é a mais adequada. Mattar (1997) complementa esta visão, uma vez que a pesquisa exploratória visa contribuir para o aumento de conhecimento sobre o tema quando o objetivo ainda está aberto, e que será necessária para criar hipóteses sobre as diferentes formas de avaliar a geração de valor social nos negócios sociais no Brasil, e para evidenciar variáveis importantes para a maximização de resultados do objeto de pesquisa. 
Segundo Malhorta (2001), a pesquisa qualitativa busca compreensão do contexto do problema por meio de pequenas amostras, devido ao estágio atual dos negócios sociais, em entrevistas não estruturadas e exploratórias. Esse tipo de pesquisa, que começou a ser utilizado na década de 1960 pelas ciências sociais aplicadas, como é o caso da administração de empresas, difere da quantitativa (GODOY, 1995). Em uma pesquisa quantitativa, o pesquisador segue um plano estabelecido e preocupa-se com a medição objetiva e a quantificação dos resultados. Já na pesquisa qualitativa, o pesquisador parte de questões ou focos de interesse amplos, que vão sendo definidos conforme a pesquisa avança. Esse tipo de pesquisa envolve obtenção de dados descritivos realizados pelo contato direto do pesquisado com o objeto de pesquisa. Isso implica a compreensão do fenômeno pela perspectiva dos participantes da situação em estudo (GODOY, 1995).

Há a intenção de consultar outras fontes relacionadas com os casos, com a finalidade de aumentar a confiabilidade dos dados. Martins (2006, p. 2) define: "Confiabilidade refere-se à consistência ou estabilidade de uma medida [...]". A confiabilidade deve vir antes da validade, uma vez que esta não se estabelece sem aquela. Uma medida que constitui parte de um estudo, ou mesmo o estudo em si, deve antes ser confiável para que possa ser pertinente, útil ou válido para algo. Por conta disso será utilizada análise documental, que tem por finalidade reunir, classificar e distribuir os documentos de todo gênero dos diferentes domínios da atividade humana, exercendo no presente estudo papel complementar às outras formas de obtenção de dados (MARTINS, 1994).

Dessa forma, com essa abordagem metodológica, será realizada a investigação das formas de avaliar os negócios sociais pela perspectiva de geração de valor social, de como estão sendo construídos e utilizados os sistemas de métricas para identificar pontos de melhorias nos negócios, para comunicação com stakeholders e para definição de alocação de recursos.

\subsection{Método}

Para cumprir o objetivo proposto por este trabalho, será realizado um estudo de casos múltiplos, utilizando-se de quatro negócios (YIN, 2003). Este estudo visa demonstrar na prática as dificuldades específicas enfrentadas pelas empresas e outros participantes do ecossistema, com a intenção de verificar como é a relação com os indicadores referentes à 
geração de valor social. A análise do caso será complementada com dados secundários, através de análise de documentos disponibilizados pelas empresas e de um levantamento de experiências que, segundo Mattar (1997), tem o objetivo de fazer com que o pesquisador aumente seu grau de consciência sobre o problema investigado. O levantamento de experiências é uma forma de documentar o conhecimento tácito, que foi acumulado através da observação e da experiência do pesquisador.

Conforme Yin (2003, p. 39):

O estudo de caso é uma investigação empírica que investiga um fenômeno contemporâneo em profundidade e em seu contexto da vida real, especialmente quando os limites entre o fenômeno e o contexto não são claramente evidentes. A investigação do estudo de caso enfrenta a situação tecnicamente diferenciada em que existirão muito mais variáveis de interesse do que pontos de dados, e, como resultado conta com múltiplas fontes de evidência, com os dados precisando convergir de maneira triangular, e como outro resultado beneficia-se do desenvolvimento anterior das proposições teóricas para orientar a coleta e a análise de dados.

Sobre as possíveis aplicações deste método, Yin (2003, p. 41) ainda afirma:

\begin{abstract}
Uma primeira aplicação dos estudos de caso é explicar os presumidos vínculos causais das intervenções da vida real que são demasiado complexos para estratégias de levantamento ou experimentais. Uma segunda aplicação é descrever uma intervenção e o contexto da vida real no qual ela ocorreu. Em terceiro lugar, os estudos de caso podem explorar as situações em que a intervenção sendo avaliada não possui um único e claro conjunto de resultados.
\end{abstract}

Para Yin (2003, p. 24), o estudo de caso é o método mais utilizado quando as questões "como" ou "por que" são propostas, quando o pesquisador tem pouco controle sobre o objeto estudado, e quando o enfoque está em um fenômeno contemporâneo: “O estudo de caso é utilizado para contribuir com o nosso conhecimento para uma diversidade muito grande de fenômenos, que vai de fenômenos individuais a fenômenos amplos, como os sociais e políticos, mas sempre se destinando a fenômenos complexos [...]".

Levando em consideração que a pergunta de pesquisa é: Como a geração de valor social é avaliada pelos negócios sociais focados em saúde no Brasil, pelos próprios empreendedores e pelas organizações de apoio deste ecossistema? Sendo um tema atual e que está em construção, o método é apropriado para a pesquisa proposta neste trabalho.

O estudo de caso será realizado por meio de entrevistas individuais informais e semiestruturadas com os empreendedores ou gestores de cada um das organizações 
envolvidas com os negócios e com organizações de apoio que têm relação direta com esses negócios. Essa visão será complementada com dados secundários, conseguidos através de documentos e relatórios disponíveis, entretanto, sem deixar que a análise histórica e de contexto sejam feitas.

Por conta da escolha metodológica, este estudo apresenta algumas limitações, assim como a impossibilidade de conclusões abrangentes e generalizações. Entretanto, por se tratar de uma pesquisa com visão preliminar, ela cumpre seu papel de sistematizar e iniciar o aprofundamento sobre o conhecimento dentro da proposta desta dissertação. "O risco consciente que o pesquisador irá enfrentar na escolha do Estudo de caso é a dificuldade de se fazer uma análise generalizante e não uma particularizante” (YIN, 2003, p. 36).

\section{$5.4 \quad$ Objeto de estudo}

Para a realização desses estudos, serão analisados quatro negócios sociais. A escolha das iniciativas teve como proposta comparar diferentes formatos organizacionais, ou seja, iniciativas criadas por diferentes atores, propósitos e origens. Dessa forma, buscou-se capturar as particularidades de cada um desses negócios em relação à formulação, uso e comunicação dos indicadores.

\subsubsection{A escolha dos casos}

O setor de saúde foi escolhido porque é um dos serviços menos oferecidos por negócios sociais. Apenas $6 \%$ dos negócios sociais mapeados oferecem produtos ou serviços ligados com a questão da saúde, estando atrás de microcrédito, educação, geração de renda, agricultura e serviços ambientais, alimentação, turismo, moradia, arte e cultura, intermediação entre comunidades e distribuidores (FUNDAÇÃO AVINA; POTENCIA VENTURES; ASPEN NETWORK OF DEVELOPMENT ENTREPRENEURS POLO BRASIL, 2011). Estabeleceram-se como critérios de escolha de casos:

1. Estar em operação; 
2. Prover soluções mercadológicas para problemas no setor da saúde à população de baixa renda;

3. Diversidade de origem e propósito da organização;

4. Diversidade do estágio do negócio;

5. Ter relacionamento próximo a algumas das organizações de fomento ao ecossistema de negócios sociais no Brasil.

Os critérios acima são importantes para que seja possível realizar o estudo. A empresa em operação é fundamental para que exista a necessidade de utilização de indicadores para gestão, comunicação de resultados e decisão de quais métricas devem ser utilizadas. As iniciativas devem atender a população de baixa renda com problemas de acesso à saúde, utilizando para isso de mecanismos de mercado. Essa definição foca em negócios sociais que seguem a definição utilizada que atua no setor da saúde. A questão do relacionamento com outros atores do ecossistema é fundamental para que seja possível identificar as diferenças de óticas utilizadas na avaliação de negócios sociais, particularmente de investidores.

Há uma variedade grande quanto à origem dos negócios sociais. Por ser algo novo e que surge entre o segundo e o terceiro setores, ou seja, entre o setor privado e organizações da sociedade civil, existem organizações dos dois setores que aderem aos negócios que buscam geração de valor econômico e social ao mesmo tempo. Há também negócios que surgem já focados nesse tipo de atuação. Acredita-se que essas diferenças de origem afetam substancialmente a forma como os indicadores são geridos e formulados. Por conta desse fato, considera-se importante analisar casos que apresentem essas diferenças.

Dentro desse mesmo desejo de analisar casos com origens diversas, é interessante entender como as diferenças de missão e de propósitos dos negócios influenciam a gestão de negócios sociais. Considera-se que empresas com propósitos declaradamente mais sociais tem uma perspectiva diferente das empresas que têm outras missões em relação às métricas e sua gestão, assim como deve acontecer com empresas que estão em estágio diferente. Empresas mais jovens ou em estágio inicial provavelmente se preocupam com indicadores de maneira 
diferenciada das empresas mais estabelecidas ou já focadas na expansão. A diferença geográfica também pode gerar diferenças nas formas como os indicadores são geridos. Empresas que estão em lugares mais afastados podem ter uma interação diferente com outros agentes do ecossistema e, portanto, têm outras dificuldades com a gestão de indicadores.

\subsubsection{Escolha de casos}

Com a finalidade de se atingir os objetivos propostos, por conveniência e facilidade de acesso a informações, e seguindo os critérios gerais e os critérios supramencionados, o Quadro 7 apresenta as empresas escolhidas.

Quadro 7 - Sugestão de casos a serem pesquisados

\begin{tabular}{|c|c|c|c|c|}
\hline \multicolumn{4}{|c|}{ Critérios utilizados } & \multirow[b]{2}{*}{ Empresa selecionada } \\
\hline $\begin{array}{c}\text { Formato } \\
\text { original }\end{array}$ & Propósito* & Estágio & $\begin{array}{l}\text { Foco de } \\
\text { atuação }\end{array}$ & \\
\hline $\begin{array}{c}\text { Negócio } \\
\text { Social }\end{array}$ & $\begin{array}{c}\text { Social e } \\
\text { mercadológico }\end{array}$ & Startup & Brasil & $\begin{array}{l}\text { SAÚTIL: } \\
\text { É uma ferramenta de busca na web criada } \\
\text { primordialmente para ajudar a população a } \\
\text { encontrar informações sobre a rede pública de } \\
\text { saúde }\end{array}$ \\
\hline $\begin{array}{l}\text { Terceiro } \\
\text { Setor }\end{array}$ & $\begin{array}{c}\text { Mais focado } \\
\text { no social }\end{array}$ & $\begin{array}{l}\text { Em operação } \\
\text { recente }\end{array}$ & $\begin{array}{l}\text { Estado de São } \\
\text { Paulo }\end{array}$ & $\begin{array}{l}\text { CIES, Centro de Integração de Educação e } \\
\text { Saúde: } \\
\text { Tem como objetivo dar à população carente } \\
\text { acesso a exames médicos de média } \\
\text { complexidade, como endoscopia, mamografia e } \\
\text { ultrassonografia, através do CIES-Móvel, que } \\
\text { consiste num caminhão adaptado e equipado } \\
\text { com aparelhos de diagnóstico de última } \\
\text { geração das doenças de maior incidência em } \\
\text { nosso país. }\end{array}$ \\
\hline $\begin{array}{l}\text { Segundo } \\
\text { Setor }\end{array}$ & $\begin{array}{l}\text { Mais focado } \\
\text { no mercado }\end{array}$ & $\begin{array}{l}\text { Consolidado } \\
\text { (em } \\
\text { expansão) }\end{array}$ & Brasil & $\begin{array}{l}\text { Sorridents: } \\
\text { Considerada a MAIOR rede de clínicas } \\
\text { odontológicas da América Latina, oferece } \\
\text { ACESSO à saúde bucal ao maior número de } \\
\text { pessoas possível. }\end{array}$ \\
\hline $\begin{array}{c}\text { Negócio } \\
\text { Social }\end{array}$ & $\begin{array}{c}\text { Mais focado } \\
\text { no social }\end{array}$ & Em operação & Fortaleza & $\begin{array}{l}\text { Clínica SiM: } \\
\text { É uma clínica popular que oferece atendimento } \\
\text { médico e odontológico a preços acessíveis. }\end{array}$ \\
\hline
\end{tabular}

*O critério de propósito é resultado de uma análise prévia das empresas escolhidas a partir de dados secundários.

Os negócios escolhidos atendem aos critérios colocados, demonstram a diversidade de origem, de propósitos, de estágio e de foco de atuação geográfica necessárias para as análises propostas. Os negócios seguem a definição conforme Comini et al. (2011), trazem soluções 
para os problemas de saúde enfrentados pela população de baixa renda, e de alguma forma já tiveram contato com agentes em comum do ecossistema de negócios sociais do Brasil.

Outro ponto que ajuda a cumprir os objetivos deste trabalho é a diversidade de soluções apresentadas pelos negócios escolhidos. As soluções a serem analisadas vão além de suprir a necessidade de alternativas ao saturado sistema público de saúde brasileiro e a oferta mais barata de tratamento médico, visto que chegam a criar modelos de negócios inovadores que são complementares a outras soluções presentes. Cada uma das empresas estudadas terá seu detalhamento no capítulo seguinte.

\subsection{Instrumento de coleta de dados}

A coleta de dados foi realizada através de entrevistas semiestruturadas. E tiveram o objetivo de gerar aprofundamento nos seguintes temas:

a) Histórico e contexto atual da empresa;

b) Conceito de Valor Social na visão dos empreendedores;

c) Indicadores utilizados no momento do estudo;

d) Utilização dos indicadores no relacionamento com outros agentes do ecossistema;

e) Processo de formulação de indicadores;

f) Utilização de indicadores nas decisões;

g) Desafios e Gaps.

As entrevistas foram feitas com pessoas de alta gestão, fundadores ou funcionários-chave presentes desde o início das atividades da empresa. As interações ocorreram entre janeiro e junho de 2013 em entrevistas presenciais, com exceção da Clínica SiM, em que foi feita uma 
conversa telefônica. O tempo médio das entrevistas foi 90 minutos e estas abrangeram todos os pontos propostos na metodologia deste trabalho. O roteiro base para a realização das entrevistas está no Apêndice.

Os dados da pesquisa foram coletados por meio de entrevistas:

1) SAÚTIL, in loco, com Edgard Morato, cofundador, em 17 de dezembro de 2012;

2) Projeto CIES, in loco, com Roberto Kikawa, fundador, e Juliana Sakai, responsável pela gestão dos indicadores, em 15 de março de 2013;

3) Sorridentes, in loco, com Rubens Rafael, diretor de Relações Institucionais, e Zumira Corrêa, ambos indicados pela fundadora Dra. Carla Sarni, em 9 de abril de 2013;

4) Clínica SiM, por telefone, com Tessiana Cândido, responsável pela gestão, onde começou a trabalhar alguns meses após a fundação, representando Denis Cruz, o fundador.

O objetivo de entrevistar os responsáveis pelas decisões é entender o papel de indicadores na gestão dos negócios, como eles são utilizados e como podem ser melhorados. Por se tratar de um estudo exploratório e qualitativo, foram realizadas triangulações dos dados colhidos com a finalidade de complementar o entendimento das questões propostas por este trabalho. Foram utilizados dados complementares: balanços patrimoniais, demonstrativos de resultados, relatórios e dados de fontes secundárias.

Com a finalidade de avaliar como os indicadores influenciam nas decisões de investimento e de negócios acelerados, assim como entender a visão de cada um deles sobre a importância da gestão dos indicadores de geração de valor social, também foram entrevistados: a) Gilberto Ribeiro, responsável por indicadores do fundo de "Impact Investing" Vox Capital; b) Renato Kiyama, Diretor da Aceleradora de Negócios da Artemisia. 


\subsection{Matriz de amarração}

A seguir são apresentadas as definições operacionais de alguns termos e conceitos utilizados no trabalho.

Para esta pesquisa, Forma de Avaliação foi considerada o sistema de indicadores que contemple a definição de métricas, padronização e divulgação dos resultados, aqueles que tenham continuidade e que sejam utilizados para algum propósito explícito. Para avaliar os sistemas serão utilizados os seguintes parâmetros, relacionados à implantação e uso de métricas, em ordem crescente de estágio de desenvolvimento, conforme demonstrado na Figura 3: Busca por métricas; Definição clara de indicadores; Mensuração Periódica; Sistematização de Relatórios; Uso da Tomada de Decisão Estratégica.

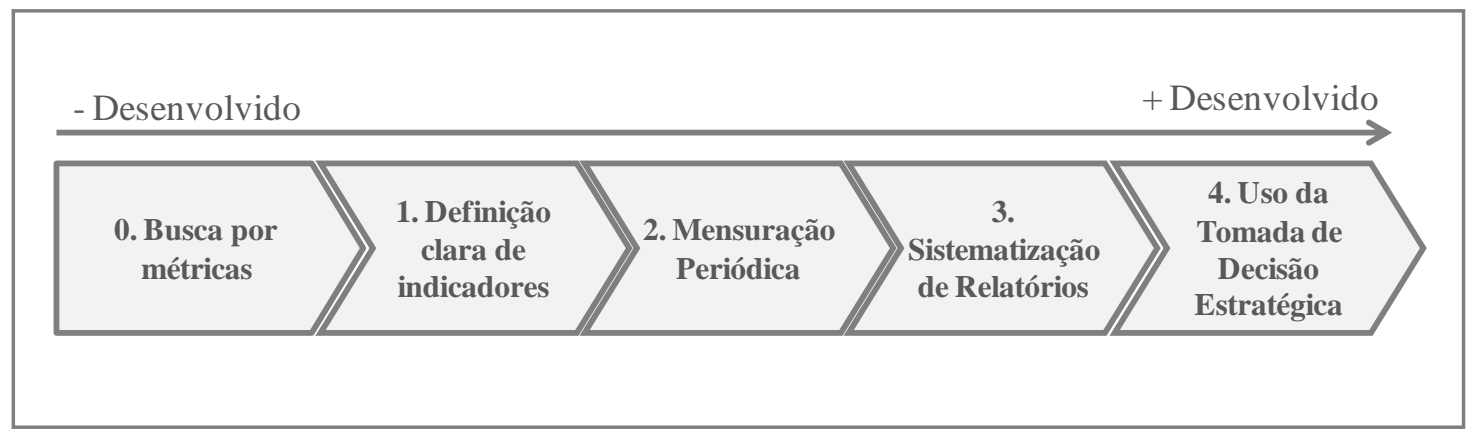

Figura 3: Parâmetros de avaliação de implantação e uso de métricas

A definição de Valor Social que foi utilizada para esta pesquisa é a busca de progresso social mediante a remoção das barreiras que dificultam a inclusão, a ajuda aos temporariamente debilitados ou que carecem de voz própria e a mitigação dos efeitos secundários indesejáveis da atividade econômica (PORTOCARRERO; DELGADO, 2010). Esta definição será utilizada considerando todas as suas divisões: inputs, outputs, incomes e impacto.

Em Negócios Sociais em saúde serão considerados os negócios e iniciativas (considerados sinônimos) que focam na solução de algum problema de saúde para a base da pirâmide, sem que seja necessária a exclusividade de atendimento a esse público. Nesses Negócios Sociais serão consideradas as iniciativas que visam solucionar problemas sociais com eficiência e sustentabilidade financeira por meio de mecanismos de mercado (COMINI et al., 2011). 
Os Atores do Ecossistema serão considerados, o conjunto de pessoas e organizações que se relacionam de alguma forma em torno da criação e desenvolvimento de negócios sociais (MOORE, 1993), focando, principalmente, nos empreendedores, nos beneficiários e nos investidores.

A matriz apresentada no Quadro 8 é uma forma de consolidar e sintetizar o problema de pesquisa, assim como seus objetivos e as referências utilizadas para desenvolver cada ponto que será investigado. 
Quadro 8 - Matriz de consolidação metodológica

\begin{tabular}{|c|c|c|c|c|c|c|c|}
\hline \multicolumn{2}{|c|}{ Objetivos da Pesquisa } & \multirow{2}{*}{$\begin{array}{c}\text { Pontos de } \\
\text { investigação } \\
\text { (questões de } \\
\text { pesquisa) }\end{array}$} & \multirow{2}{*}{$\begin{array}{c}\text { Fundamentação } \\
\text { teórica }\end{array}$} & \multirow{2}{*}{$\begin{array}{l}\text { Principais } \\
\text { fontes }\end{array}$} & \multirow{2}{*}{$\begin{array}{c}\text { Técnicas de } \\
\text { coleta dos dados }\end{array}$} & \multirow{2}{*}{$\begin{array}{l}\text { Técnicas } \\
\text { de análise } \\
\text { dos dados }\end{array}$} & \multirow{2}{*}{ Resultado esperado } \\
\hline Geral & Específicos & & & & & & \\
\hline \multirow{4}{*}{$\begin{array}{c}\text { Identificar e } \\
\text { comparar } \\
\text { formas de } \\
\text { avaliação de } \\
\text { geração de } \\
\text { valor social, } \\
\text { para negócios } \\
\text { sociais focados } \\
\text { em saúde no } \\
\text { Brasil, nas } \\
\text { perspectivas de } \\
\text { diferentes } \\
\text { atores deste } \\
\text { ecossistema. }\end{array}$} & $\begin{array}{c}\text { Identificar principais } \\
\text { ferramentas, metodologias e } \\
\text { frameworks utilizados por } \\
\text { empreendedores, beneficiários } \\
\text { e investidores na mensuração } \\
\text { de valor social gerado. }\end{array}$ & $\begin{array}{l}\text { Quais são os sistemas } \\
\text { de avaliação utilizados } \\
\text { pelos agentes do } \\
\text { ecossistema de } \\
\text { negócios sociais no } \\
\text { Brasil? }\end{array}$ & $\begin{array}{l}\text { Mensuração de valor } \\
\text { social. }\end{array}$ & $\begin{array}{l}\text { Portocarrero e } \\
\text { Delgado; } \\
\text { Oliveira Filho, } \\
\text { Kiyama e } \\
\text { Comini; IRIS; } \\
\text { GIIRS; SROI; } \\
\end{array}$ & $\begin{array}{c}\text { Entrevistas, } \\
\text { levantamento de } \\
\text { dados secundários } \\
\text { e revisão } \\
\text { bibliográfica. }\end{array}$ & \begin{tabular}{|l} 
Análise de \\
conteúdo da \\
entrevista e \\
dos dados \\
fornecidos.
\end{tabular} & $\begin{array}{c}\text { Sistemas utilizados e } \\
\text { resultados } \\
\text { identificados. }\end{array}$ \\
\hline & $\begin{array}{l}\text { Identificar principais desafios } \\
\text { na mensuração, na } \\
\text { formulação, no } \\
\text { acompanhamento e na } \\
\text { comparação de indicadores de } \\
\text { mensuração de valor social. }\end{array}$ & $\begin{array}{l}\text { Quais as dificuldades } \\
\text { na formulação e } \\
\text { utilização dos } \\
\text { sistemas de avaliação } \\
\text { utilizados? }\end{array}$ & $\begin{array}{c}\text { Formulação e gestão } \\
\text { de indicadores } \\
\text { socioambientais. }\end{array}$ & $\begin{array}{l}\text { Calil; Oliveira } \\
\text { Filho, Kiyama e } \\
\text { Comini; SROI; }\end{array}$ & $\begin{array}{c}\text { Entrevistas, } \\
\text { levantamento de } \\
\text { dados secundários } \\
\text { e revisão } \\
\text { bibliográfica. }\end{array}$ & $\begin{array}{l}\text { Análise de } \\
\text { conteúdo da } \\
\text { entrevista e } \\
\text { dos dados } \\
\text { fornecidos. }\end{array}$ & $\begin{array}{c}\text { Principais } \\
\text { necessidades não } \\
\text { atendidas pelas } \\
\text { ferramentas atuais e } \\
\text { formas alternativas } \\
\text { de realizar o } \\
\text { monitoramento de } \\
\text { indicadores } \\
\text { socioambientais. }\end{array}$ \\
\hline & $\begin{array}{l}\text { Analisar a base de dados e os } \\
\text { resultados existentes de } \\
\text { indicadores e identificar } \\
\text { benefícios trazidos ao } \\
\text { ecossistema. }\end{array}$ & $\begin{array}{l}\text { Qual é a contribuição } \\
\text { dos indicadores para o } \\
\text { desenvolvimento do } \\
\text { ecossistema? }\end{array}$ & $\begin{array}{c}\text { Ecossistema e } \\
\text { negócios sociais. }\end{array}$ & $\begin{array}{l}\text { Reficco e } \\
\text { Vernis; Comini } \\
\text { e Teodósio et } \\
\text { al.; Ferrary e } \\
\text { Granovetter }\end{array}$ & $\begin{array}{c}\text { Entrevistas, } \\
\text { levantamento de } \\
\text { dados secundários } \\
\text { e revisão } \\
\text { bibliográfica. }\end{array}$ & $\begin{array}{l}\text { Análise de } \\
\text { conteúdo da } \\
\text { entrevista e } \\
\text { dos dados } \\
\text { fornecidos. }\end{array}$ & $\begin{array}{c}\text { Formas de utilização } \\
\text { dos indicadores como } \\
\text { ferramenta de } \\
\text { interação entre os } \\
\text { agentes do } \\
\text { ecossistema de } \\
\text { negócios sociais. }\end{array}$ \\
\hline & $\begin{array}{c}\text { Identificar as barreiras e } \\
\text { oportunidades para o uso de } \\
\text { indicadores no } \\
\text { direcionamento estratégico } \\
\text { dos negócios. }\end{array}$ & $\begin{array}{l}\text { De que forma o uso de } \\
\text { indicadores na } \\
\text { reformulação } \\
\text { estratégica podem ser } \\
\text { melhor utilizados? }\end{array}$ & $\begin{array}{c}\text { Ecossistema e } \\
\text { negócios sociais. }\end{array}$ & $\begin{array}{c}\text { Reficco e } \\
\text { Vernis; Comini } \\
\text { e Teodósio et } \\
\text { al.; Ferrary e } \\
\text { Granovetter }\end{array}$ & $\begin{array}{l}\text { Entrevistas e } \\
\text { questionários. }\end{array}$ & \begin{tabular}{|l} 
Análise de \\
conteúdo da \\
entrevista e \\
dos dados \\
fornecidos.
\end{tabular} & $\begin{array}{c}\text { Possibilidades e } \\
\text { alternativas que } \\
\text { tragam melhoria e } \\
\text { avanço na forma em } \\
\text { que o ecossistema de } \\
\text { negócios sociais é } \\
\text { pautado. }\end{array}$ \\
\hline
\end{tabular}




\section{APRESENTAÇÃO DOS CASOS E RESULTADOS}

O objetivo deste capítulo é caracterizar os negócios sociais escolhidos para fazerem parte desta dissertação, bem como descrever como são utilizados os indicadores na gestão das metas sociais e econômicas destes negócios.

Além disso, pretende-se discutir como o uso de indicadores pode contribuir para que a empresa obtenha mais efetividade de suas ações sociais e econômicas, mas principalmente como esses indicadores diferenciam os negócios que mais geram maior valor social e lucratividade de forma mesclada.

Primeiramente é descrita cada empresa, individualmente e, em seguida, são feitas as análises comparativas e enumerados os pontos em comum.

\subsection{Saútil}

\subsubsection{Breve histórico da empresa}

A empresa Saútil foi fundada por Fernando Fernandes, formado em medicina com atuação em gestão de empresas ligadas à medicina, e Edgar Morato, publicitário proprietário de uma agência. Ambos já havia tido sucesso em suas atividades profissionais e escolheram realizar uma transição com a clara intenção de "fazer o bem”, nas palavras de Edgard.

Pelo conhecimento de Fernando, sabiam que havia oportunidades no campo da saúde e que o SUS era subutilizado muitas vezes pela dificuldade dos pacientes em conseguir a informação que precisavam. Surgiu então a ideia de uma ferramenta de busca na web para "traduzir" o SUS, com informações sobre os medicamentos fornecidos gratuitamente e onde retirá-los.

As atividades começaram em 2010 e o site foi lançado em 2011, já com medicamentos, vacinas, consultas, exames e postos de saúde para a cidade de São Paulo. O público-alvo eram pessoas das classes C e D sem plano de saúde. 
A empresa passou pelo processo de aceleração de negócios da Artemisia $^{4}$ e faz parte do portfólio de investimento da Vox Capital. ${ }^{5}$

6.1.2 Geração de valor social

A Saútil tem como propósito ajudar a população a encontrar informações sobre os serviços oferecidos pelo SUS gratuitamente. Sua ferramenta de busca na web é capaz de trazer informações que estão dispersas em diversos portais do governo de maneira simples aos usuários, além de contar com conteúdo técnico e confiável sobre principais doenças, prevenção e de dar acesso a produtos de baixo custo no Brasil. O site, em julho de 2013, tinha cerca de 50 mil acessos por mês, tinha o cadastro de 6 mil usuários, 12 mil assinantes das newsletter sobre saúde e já havia realizado 170 mil pesquisas de medicamentos. Sua base de dados conta com 48.014 unidades de saúde cadastradas e 5.566 municípios cadastrados.

\subsubsection{Modelo de negócio da empresa}

A empresa possui como fontes de receitas: publicidade de empresas farmacêuticas e um serviço vendido para quem contrata funcionários sem plano de saúde, que consiste em fornecer informações de saúde via atendimento telefônico. Essa receita consegue fazer com que a empresa tenha sustentabilidade financeira.

\subsubsection{Indicadores}

A gestão de indicadores de receita, margem e custos é feita integrada a processos, padronizada e com frequência definida de divulgação. Sendo, ainda, utilizada para a tomada de decisões de gestão. Entretanto, apesar de os fundadores se preocuparem com o impacto social gerado e terem a intenção de "nunca deixar de lado a questão do impacto (social)",

\footnotetext{
${ }^{4}$ Organização pioneira e referência em negócios sociais no Brasil, a empresa potencializa e capacita talentos e empreendedores para a geração de negócios de alto impacto social por meio de iniciativas nas áreas de educação, disseminação de conhecimento e aceleração de negócios sociais. Foi fundada em 2004 pela Potencia Ventures.

${ }^{5}$ Fundo de Capital empreendedor que investe em empresas inovadoras e de alto potencial que servem a população de baixa renda, e cujas atividades contribuem para a redução da pobreza.
} 
conforme mencionado em entrevista, ainda não contam com uma estrutura definida de um painel de métricas utilizadas.

Em 2012, uma pesquisa realizada com a Vox Capital sobre quem utiliza o serviço da Saútil nas cidades de Belo Horizonte, Curitiba e Salvador, apontou que 90\% dos usuários estão na periferia. Essa informação reforça o resultado de atender a população de baixa renda e deve ser acompanhada e controlada, para que os resultados se mantenham.

Outro ponto importante é a iniciativa de implementar o GIIRS, influenciada pelo investidor. Entretanto, a primeira tentativa com o padrão de métricas não foi positiva. Na visão do entrevistado, o foco dos indicadores ainda é inadequado para expressar o impacto gerado por conta de "questões muito práticas". Um dos exemplos citados refere-se a responder questões como quantidade de mulheres na equipe e outras informações institucionais que não contribuem para a demonstração do impacto gerado de uma startup como a Saútil. Essas questões se tornam relevantes após a empresa ter um determinado tamanho e servem mais como dados de avaliação da política de gestão de recursos humanos do que de geração de valor pela atividade fim da organização.

Ele acredita que eles "possivelmente irão criar metodologia própria", algo mais adequado ao serviço que eles prestam e ao momento da empresa. Isso provavelmente será realizado "depois do produto estar estabelecido, pois terão mais tempo para desenvolver a metodologia de medir impacto".

Os sócios apresentam também um plano de onde devem avançar para conseguir aprimorar a mensuração do impacto medido. Sabem que devem evoluir na busca de informações se o paciente conseguiu ou não efetivamente realizar o exame, a consulta ou obter o medicamento, uma vez que, até este momento, eles só contavam com a informação das buscas realizadas no site e dos resultados destas buscas. O plano de melhoria de indicadores está sendo realizado em parceria com o investidor.

A empresa acredita que contribui para a redução da fila de espera na realização de exames e consultas, que mais pessoas têm acesso à informação, proporcionando melhor tratamento, e que isso possibilita um aumento de qualidade na saúde do público-alvo. Essas informações devem ser checadas pelos indicadores em implantação. 
O principal objetivo para o entrevistado, em melhorar a gestão de métricas, é aumentar a credibilidade da ferramenta, aumentar a transparência da entrega de benefícios sociais perante o ecossistema e maximizar a geração de valor social, sem que isso reduza o potencial de escala do negócio.

\subsection{Projeto CIES}

\subsubsection{Breve histórico da empresa}

Proveniente da Associação Beneficente Ebenézer, o Projeto CIES realizou sua primeira ação em 2008. Fundado por Roberto Kikawa, médico comprometido em levar acesso a exames e procedimentos médicos à população não completamente atendida pelo SUS, atua de maneira humanizada, conforme prometido para seu pai.

Após ter realizado estudos de muitos modelos de atendimento médico móvel, Roberto Kikawa percebeu que modelos como Caminhão Siemens e Caminhão Philips, que proporcionavam ressonância magnética nos EUA e mamografia na Argentina e Brasil, respectivamente, apresentavam dificuldades em garantir a sustentabilidade financeira, por depender de dinheiro do patrocinador ou fundador.

Roberto Kikawa, então, criou uma organização sem fins lucrativos, que usaria o modelo de atendimento móvel de qualidade, especializado, humanizado e de alta tecnologia, utilizando caminhões que poderiam levar atendimento para as pessoas de baixa renda, privadas de atendimento médico de qualidade. $\mathrm{O}$ foco desse atendimento além de realizar tratamentos era o de educar e atuar na prevenção de doenças.

Desde então, realizou parceria com fabricantes de equipamentos, com um hospital e com uma empresa de engenharia para a construção da unidade móvel, e hoje conta com uma carreta, dois containers e uma van para prestar o atendimento a mais de 25 mil beneficiários e realizar mais de 50 mil exames e procedimentos. Além disso, foi vencedor do prêmio Empreendedor Social da Folha de São Paulo de 2010, em reconhecimento ao serviço social prestado pelo CIES, e participou do programa de aceleração da Artemisia. 


\subsubsection{Geração de valor social}

Dado que a maioria da população (cerca de $75 \%$ ) depende de tratamento médico do SUS, e que uma das maiores deficiências desse sistema são as longas filas de espera para realização de exames e procedimentos de média complexidade, o CIES provém de parcerias com órgãos públicos, e faz o atendimento de 10 especialidades médicas ${ }^{6}$ por meio de um atendimento móvel. O Projeto também realiza atividades de educação e informação sobre a saúde e como utilizar o sistema público, por meio de palestras com médicos e atividades de prevenção.

As atividades do CIES ocorrem em quatro frentes: a) a Carreta Saúde, uma unidade móvel capaz de realizar tratamentos das 10 especialidades médicas em cidades de mais de 100 mil habitantes, conseguindo atender cerca de 200 pacientes por dia, auxiliando a reduzir a espera por atendimento; b) o Box da Saúde, unidade móvel que pode ser transportada por rodovias e rios que atende no máximo quatro especialidades, capaz de atender 100 pessoas por dia em cidades pequenas (menores que 100 mil habitantes) e cidades ribeirinhas; c) é também a Van da Saúde, unidade móvel focada em exames radiológicos digitais e ultrassom / Ecocardiografia, com capacidade de atendimento de 50 pessoas por dia; d) outra atividade realizada pelo CIES, que consiste em uma unidade fixa em parceria com as prefeituras e organizações locais, onde o local oferecido é utilizado como clínica e os pacientes são levados até lá. Essa iniciativa já está funcionando em três diferentes cidades.

Com essa variedade de serviços, todos baseados no conceito de saúde humanizada, com atendimento focado em educação e prevenção, e com a utilização de equipamentos de alta tecnologia, o CIES busca reduzir o déficit de população que não tem atendimento de procedimentos de média complexidade.

\subsubsection{Modelo de negócio da empresa}

Para conseguir a sustentabilidade financeira, o CIES atua, fundamentalmente, como fornecedor do SUS, recebendo conforme a tabela estabelecida pelo órgão. A parceria com o

\footnotetext{
${ }^{6}$ Coleta de Exames; Cardiologia (Ecocardiograma); Oftalmologia; Otorrinolaringologia; Urologia; Ginecologia; Vascular; Dermatologia; Pediatria; Gastroenterologia (Endoscopia/Colonoscopia); Mamografia; Ultrassonografia; Audiometria; Coleta de exames laboratoriais; Pequenas cirurgias.
} 
SUS é responsável por $60 \%$ da receita da organização. Além dessa forma de remuneração, são realizados atendimentos para os colaboradores e comunidades do entorno dos principais parceiros que representam $15 \%$ do faturamento, $10 \%$ são conseguidos de clientes privados e os outros $15 \%$ do faturamento são provenientes de doações.

O CIES só se viabiliza financeiramente porque consegue ser eficiente e ter custos menores que os custos apresentados pela rede pública de saúde. Dessa forma, consegue fazer com que a rentabilidade da parceria com o SUS seja possível para manter a estrutura necessária e para investir em outras iniciativas. Pela alta dependência da parceria com o SUS, há a intenção de realizar uma parceira diferente com o governo e trabalhar de maneira menos dependente do SUS.

\subsubsection{Indicadores}

O CIES possui dados padronizados, que são monitorados com frequência mensal e que estão em um documento formal da empresa, chamado de Relatório Anual. Os mesmos dados são capturados desde 2007 e são utilizados para controlar o valor social gerado e para gerar melhorias nas atividades realizadas. Além disso, o CIES possui um relatório mais detalhado de suas atividades em duas cidades.

O relatório anual, feito em inglês, agrega informações sobre produtos-atividades, governança e dados financeiros bem estruturados de 2007 a 2011, mostrando um acompanhamento estruturado das atividades. Além dos principais dados financeiros, esse relatório conta com números de atendimentos, procedimentos realizados e quantidade de cidades atendidas.

Em conjunto com uma organização Planète d'Entrepreneurs, foi realizado um estudo do impacto gerado em fevereiro de 2013 utilizando o framework do SROI. A análise focou em 364 pacientes atendidos pelo CIES em São José dos Campos e São Francisco do Sul, além de ter identificado as métricas mais relevantes, tais como: tempo de espera para realizar uma consulta, para rever o mesmo especialista, expectativas e impressões de realizar consultas em uma unidade móvel, percepção do atendimento da equipe do CIES, entre outros. 
Os principais resultados desse estudo mostram que, em um ano, as filas foram reduzidas de 70 mil para 37 mil na cidade de São José dos Campos, e de 5 mil para quase zero em São Francisco do Sul. O tempo médio de espera para ser atendido foi reduzido de 5,6 meses para 3,2 meses com o CIES, sendo que 40\% dos pacientes esperavam mais que cinco meses e após a intervenção do CIES, apenas $15 \%$ os pacientes apresentaram a mesma situação. O tempo para chegar à consulta foi reduzido de 32 minutos para 28 minutos. O Estudo também traçou o perfil do usuário, mensurou o nível de conhecimento sobre a iniciativa e a percepção de qualidade.

As conclusões do estudo demonstram com dados quantitativos e qualitativos que o CIES consegue prover atendimento com melhor qualidade que o SUS, conseguindo aumentar o acesso, reduzir a espera e a distância que o paciente percorre para chegar ao local do tratamento, mesmo ainda com uma deficiência na comunicação e divulgação das atividades que o CIES proporciona.

Este estudo demonstra que o CIES já tem uma estrutura de métricas que são acompanhados regularmente, entretanto, ainda deve avançar em relação aos indicadores, notadamente, na geração de valor social, uma vez que contou com uma organização preparada para realizar esse tipo de análise.

$\mathrm{Na}$ visão do fundador, o CIES tem muito a melhorar em relação à estrutura de processo e na gestão de indicadores, no entanto, ele já possui uma profissional focada nesse ponto de melhoria. O desejo do olhar mais cuidadoso sobre os indicadores vem do foco na transparência que o fundador tem e no desejo de conseguir diferenciar o CIES de iniciativas que não geram tanto valor social ou que não têm a independência financeira que eles apresentam. Afirma, ainda, que é "importante que os indicadores sejam padronizados e que exista um selo de acreditação" para negócios sociais.

O fundador acredita que, além do uso dos indicadores na gestão, esses devem ser uma das formas de delimitar os negócios que realmente têm preocupação social e possuem sustentabilidade financeira dos negócios convencionais e de ONGs. A preocupação se dá para que o ecossistema e, principalmente, os investidores, consigam segmentar melhor o que eles buscam e oferecer capital de foram mais apropriada. 


\subsection{Sorridents}

\subsubsection{Breve histórico da empresa}

A empresa foi fundada por uma dentista mineira, a Dra. Carla Sarni, na zona leste de São Paulo, década de 1990. Na medida em que a clínica foi prosperando, a fundadora investia em sua melhoria, a fim de poder proporcionar mais conforto para os pacientes e criar um diferencial na região, atraindo outros dentistas. Além da melhoria no atendimento, sempre foi uma prática da Dra. Carla realizar atendimentos gratuitos para a população carente, por entender a necessidade das pessoas no entorno de seu consultório.

Em cerca de 10 anos, a Dra. Carla já era sócia de 19 clínicas que seguiam os padrões de conforto e qualidade idealizados por ela. Em 2005, foi estruturado o modelo de franquia. Hoje a Sorridentes possui mais de 180 franquias, sendo 45 clínicas próprias no país e diversos reconhecimentos do modelo de franquia de sucesso e pelos trabalhos sociais realizados de instituições, como a Associação Brasileira de Franchising e da revista Pequenas Empresas e Grandes Negócios.

Em 2008, foi criado o Instituto Sorridents, que centraliza as ações sociais realizadas pela empresa. A Dra. Carla afirma que "Em nenhum momento, inclusive momentos de crise, a Sorridents esqueceu e deixou de investir nas questões sociais", pois o "O instituto está no DNA da empresa.” Ou seja, a preocupação social está presente nas decisões da empresa. E ainda as ações ajudam a empresa a conseguir mais franqueados e criar vínculos com a população que atende.

\subsubsection{Geração de valor social}

A empresa tem um histórico de atuação social por meio de iniciativas e projetos sociais e, principalmente, uma atuação focada em pessoas das classes C e D, seja pela preocupação clara de realizar tratamentos odontológicos por baixo custo, seja pela própria localidade de suas clínicas. 
As ações de responsabilidade social acontecem desde o início das atividades da Sorridents e envolvem os franqueados. Há um programa chamado de Sorrimóvel, em que uma unidade móvel leva tratamento, diagnósticos, informações e palestras sobre prevenção para bairros afastados e para eventos sociais. O outro programa, "Adote uma Criança", atua oferecendo tratamentos gratuitos para crianças matriculadas em escolas, e que apresentam problemas de desempenho escolar por conta de problemas bucais.

No entanto, a principal atuação social da Sorridents acontece em sua atividade fim, ou seja, na oferta de tratamento dentário de qualidade. O foco de atendimento da Sorridents é o público das classes C e D, baseado em uma visão clara de mercado. Ou seja, a empresa decidiu por esse público-alvo por considerar que é um mercado interessante, que demanda tratamento acessível. Outra decisão que impacta diretamente no número de atendimentos e no acesso é a escolha do modelo de expansão por meio de franquias, que possibilita rápido crescimento de unidades espalhadas por todo país.

Para obter sucesso em sua atuação, uma das formas de captação de novos pacientes é o trabalho de prevenção e avaliação que é realizado nas escolas de maneira gratuita. Ou seja, gera benefício para os atendidos e normalmente consegue angariar atendimentos. Esses diagnósticos, em muitos casos, detectam doenças graves que precisam de tratamento urgente, minimizando as consequências do problema de saúde e direcionando o tratamento.

\subsubsection{Modelo de negócio da empresa}

A empresa tem sua receita proveniente das consultas. Entretanto, é focada em atendimento de população de baixo poder aquisitivo, portanto, deve apresentar baixos preços e grande número de atendimentos. Para conseguir preços acessíveis e de qualidade, a Sorridents conta com padronização dos serviços e produtos utilizados nos atendimentos, conta com uma central única de compras que consegue negociar melhores preços, além de contar com os serviços habituais de uma franquia, como treinamentos, divulgação, consultoria de qualidade, assessoria jurídica. Essas ações garantem que a Sorridents seja uma empresa de grande importância em seu segmento de mercado, em 2013 era a maior rede de odontologia no Brasil e a segunda no mundo. 


\subsubsection{Indicadores}

A Sorridents coleta seus dados por meio de um software próprio, gerando uma base de indicadores confiável e dentro de um processo estabelecido. Esses dados são focados na geração de valor econômico, que os auxilia na tomada de decisão e, portanto, estão presentes em relatório gerenciais. No entanto, esses dados também são fonte de informações para entender o impacto gerado, principalmente no controle dos outputs.

São monitorados, entre outros indicadores, tipos de tratamento, ticket médio, lead time de resolução de reclamações e nível de qualidade. Com esses indicadores a organização consegue saber como as unidades estão se desempenhando e atuar para que os clientes sejam bem atendidos e as unidades sejam lucrativas.

O principal indicador controlado é o preço do atendimento. Regularmente, a empresa realiza pesquisa de preços, para que seja realmente acessível ou competitivo. O Sr. Rubens Rafael, responsável pelo Instituto Sorridents, afirma que a "Sorridents jamais aumentou a margem e que em 8 anos a tabela de preço aumentou apenas duas vezes." Dessa forma, a empresa continua atendendo pessoas de baixa renda, mesmo com o aumento de concorrência neste segmento.

A empresa, representada pelo instituto, monitora as mudanças na comunidade no entorno das franquias, como o avanço de renda e a melhoria da economia da microrregião, dado que a presença das unidades ocorre em regiões com pouca presença e investimento do governo. Essa medida se torna importante para entender como o mercado alvo se desenvolve. Essa medida ainda deve se desenvolver, de acordo com o Interlocutor.

Um exemplo citado foi a questão do aumento de implantes realizados, que substituem as dentaduras e que, na avaliação da empresa, é fruto de mais informação, do aumento de crédito e da redução do preço do tratamento, gerando acesso a tratamentos mais adequados ao paciente.

De maneira mais qualitativa, a empresa acredita que os tipos de tratamento refletem o impacto gerado pelas ações da Sorridents, incluindo, principalmente, as ações nas escolas, que, como foi dito, foca na prevenção, informação e no diagnóstico. Com isso, além da empresa 
aumentar o número de pacientes, consegue diagnosticar e tratar problemas bucais em estágio inicial, diminuindo o risco de consequências aos pacientes. Além disso, as ações em escolas também gera um relatório das avaliações que podem ser utilizadas para informar pais e reforçar a educação sobre saúde bucal nas escolas.

Assim como essas ações em escolas, quanto à visão de impacto causada por implantes e os benefícios trazidos para a comunidade do entorno, fica a cargo do instituto, ou seja, não é visto como uma atitude de negócio, e sim como uma ação de responsabilidade social. Seu site dá destaque para os prêmios recebidos pela Associação Brasileira de Franchising, especificamente no Prêmio ABF-AFRAS Destaque em Responsabilidade Social, obteve o $1^{\circ}$ lugar em 2011, o $2^{\circ}$ lugar em 2010 e o $1^{\circ}$ lugar em 2009. No entanto, isso não invalida a importância e valor social gerado por esta empresa.

\subsection{Clínica SiM}

6.4.1 Breve histórico da empresa

A Clínica SiM foi fundada em 2007 pelo empreendedor Denis Cruz, administrador, filho de médicos proprietários de um hospital em Fortaleza, CE. Percebendo que na grande parte da população as pessoas que não possuíam plano de saúde não eram tratadas de forma adequada pelo SUS, resolveu desenvolver uma forma de atender rapidamente as pessoas que aguardavam por muito tempo para realizar consultas eletivas e exames preventivos.

Denis percebeu que a demanda existia e que as clínicas que realizavam estes exames não ofereciam qualidade e atendimento adequados. Além disso, Denis tinha a clara intenção de "fazer bem para a Sociedade", como disse Tessiana Cândido, responsável pela gestão da empresa.

As primeiras experiências foram realizadas no hospital dos pais de Denis. Com isso, ele teria um lugar adequado e presença dos médicos que já trabalhavam no local. Isso aconteceu até 2009, entretanto, a operação era deficitária e precisava do apoio financeiro do Hospital para operar. 
Em 2009, a clínica mudou para um lugar próprio, e devido a ações de marketing, o número de atendimentos começou a aumentar, assim como o conhecimento e reconhecimento do público. Em 2011, já estavam gerando lucro. Hoje oferecem 20 especialidades médicas, realizam cerca de 3 mil atendimentos por mês e a demanda tem aumentado. Por conta desse aumento de procura pela Clínica SiM, está sendo desenvolvido um sistema de expansão por franquia e uma nova clínica está sendo construída por um investidor.

\subsubsection{Geração de valor social}

A empresa foi constituída para realizar atendimentos que o SUS não consegue oferecer de maneira eficiente. Um dos principais problemas apresentados pelo sistema brasileiro de saúde é o atendimento secundário, ou seja, consultas de especialistas e exames de diagnósticos. A Clínica SiM foi constituída para gerar acesso a este público com velocidade e qualidade, realizando consultas e exames com espera máxima de uma semana, o que no SUS demoraria de 6 a 24 meses.

O público da Clínica SiM tinha o foco nas classes C, D e E, mas estava atendendo todas as pessoas, inclusive pessoas com plano de saúde. Por conta disto tem se dedicado a focar na comunicação de que a Clínica SiM é uma clínica acessível. Além disso, pretende oferecer o maior portfólio de exames, inclusive realizando parceria em outros setores como com Clínicas de Fisioterapia, que atendem com preços especiais.

\subsubsection{Modelo de negócio da empresa}

A fonte de receita da Clínica SiM são os atendimentos e consultas. A Clínica SiM não possui outras fontes de receita, diferentemente de quando tinha o apoio do Hospital em que ficava alocada. Dessa forma, a gestão financeira é feita com rigor e de forma a garantir a acessibilidade dos serviços e a qualidade.

Um dos grandes problemas para atingir esses objetivos é o pagamento dos médicos. De acordo com a entrevistada, quem trabalha na Clínica SiM "deve comprar a causa". Mesmo oferecendo remuneração dentro da média do mercado, o turnover é alto, já que existem 
clínicas particulares que oferecem salários mais altos. Por conta disto, é oferecido aos médicos que atendem pela Clínica SiM mais flexibilidade de horários e itens de conforto não oferecidos por outras clínicas, como salas de descompressão, comida e um ambiente diferenciado, para que os médicos estejam motivados e se identifiquem com o propósito.

\subsubsection{Indicadores}

Tessiana Cândido declarou que a empresa "tem muito a avançar" no monitoramento dos resultados sociais conseguidos e que "começaram a realizar a gestão em 2012". Foram demonstrados dados estruturados de atendimento e público que frequenta a clínica.

O público que é atendido pela clínica, de acordo com pesquisa realizada pela empresa em 2012, é, em sua maioria, formado por mulheres jovens (28 a 36 anos) com renda de 1 a 3 salários mínimos, e de bairros próximos à clínica. Em sua maioria têm emprego fixo. E não têm plano de saúde. Cerca de $80 \%$ dos pacientes é particular e $20 \%$ são atendidos por meio de planos de saúde.

A gestão da empresa é baseada nos indicadores de quantidade de atendimentos, números de chamadas, número de agendamentos e índice de qualidade, pesquisa realizada três vezes por dia com os pacientes.

Em 2009, foi realizado um levantamento pela Clínica SiM com o objetivo de entender o que aconteceu com os pacientes que foram atendidos em 2008. Foram feitas cerca de 100 ligações por mês. O resultado foi que $60 \%$ das pessoas continuavam a utilizar a Clínica SiM ou alguma outra clínica popular, sendo que uma parte das pessoas que não utilizam mais começaram a utilizar planos de saúde.

A Clínica SiM também pesquisou como seus pacientes realizavam seus exames anteriormente. $\mathrm{O}$ estudo mostra que as pessoas utilizavam o SUS ou não realizavam os exames. Isso mostra a importância da empresa no atendimento. O preço é outra medida importante. Por conta disso, são realizadas pesquisas de preços de outras clínicas para que mantenham o preço acessível e dentro do padrão de mercado. 
Por conta do preço baixo, o fluxo de atendimentos deve ser alto, e nem todos os horários são preenchidos, portanto, são atendidas as pessoas das classes A e B, em alguns casos via planos de saúde conveniados. Esse dado, no entanto, é monitorado para que o nível de atendimento e o tempo de espera não prejudiquem as outras pessoas, o que apresenta um risco de prejuízo ao atendimento do público alvo.

A gestora Tessiana Cândido afirma que o impacto social é medido pelo feeling. Uma das formas é saber quantos diagnósticos de câncer são realizados, e se esses diagnósticos estão ajudando as pessoas a conseguir realizar o tratamento correto com antecedência, uma vez que demorariam mais para realizar os exames se dependessem do SUS. Ela admite dificuldades em capturar os resultados e a necessidade de se realizar de maneira mais precisa e mais frequente essa pesquisa; constata que a maior barreira para tanto são os custos e equipe para realizar essas análises.

Esses resultados de geração de valor social seriam utilizados para demonstrar, para a equipe médica e para o paciente da Clínica SiM, o foco em resultados sociais, e desta forma motivar a equipe e demonstrar aos pacientes os objetivos reais da empresa. A Clínica SiM, antes de receber a aceleração da Artemisia, em 2011, não tinha conhecimento com metodologias de IRIS, GIIRS, SROI. Nas palavras da entrevistada "é importante que o conjunto dos indicadores seja padronizado, para que os diferenciais da clínica sejam demonstrados para todos os stakeholders."

\subsection{Discussão sobre os resultados e análise comparativa dos casos}

Conforme as descrições dos casos apresentados, há certa diversidade na forma de atuar e de gerar valor social e econômico dos negócios estudados, segundo demonstrado no Quadro 9. Os negócios estudados apresentam uma solução viável para se chegar na sustentabilidade financeira e geram benefícios tangíveis para a população que não tem acesso pleno a serviços de saúde. Estes benefícios se concentram no acesso à serviços médicos e, no caso da Saútil, no acesso às informações para que os beneficiários utilizem melhor as alternativas públicas das quais têm direito. No Quadro 9 foi utilizada a classificação de tipo de impacto criada por Portocarrero e Delgado (2010) para caracterizar cada um dos negócios estudados. 
Quadro 9 - Síntese dos casos estudados

\begin{tabular}{|c|c|c|c|c|}
\hline Empresa & $\begin{array}{c}\text { Ano de } \\
\text { fundação }\end{array}$ & Foco de atuação & $\begin{array}{c}\text { Principal fonte de } \\
\text { receita }\end{array}$ & Tipo de impacto* \\
\hline Saútil & 2010 & $\begin{array}{c}\text { Acesso a informações de serviços } \\
\text { públicos }\end{array}$ & $\begin{array}{c}\text { Publicidade e } \\
\text { atendimento telefônico }\end{array}$ & $\begin{array}{c}\text { Promoção de } \\
\text { cidadania }\end{array}$ \\
\hline Projeto CIES & 2008 & $\begin{array}{c}\text { Acesso à atenção de média } \\
\text { complexidade (consultas e } \\
\text { exames) }\end{array}$ & Parceira com o SUS & $\begin{array}{c}\text { Acesso aos bens e } \\
\text { serviços }\end{array}$ \\
\hline Sorridents & 1995 & $\begin{array}{c}\text { Acesso a tratamento dentário e } \\
\text { cirurgias dentárias }\end{array}$ & $\begin{array}{c}\text { Atendimento a clientes } \\
\text { Clínica SiM }\end{array} 2007$ & $\begin{array}{c}\text { Acesso à atenção de média } \\
\text { complexidade (consultas e } \\
\text { exames) e tratamento dentário } \\
\text { serviços }\end{array}$ \\
\hline
\end{tabular}

*Critérios adotados por Portocarrero e Delgado (2010).

Além do tipo de impacto e das diversas formas de geração receita, é possível verificar que existe uma certa diferenciação em como cada um faz o balanço entre geração de valor social e econômico. A Figura 4 mostra, de uma forma qualitativa, como cada uma das empresas se posiciona sobre as questões relevantes aos negócios sociais: sustentabilidade financeira e foco no atendimento à população de baixa renda. Quanto maior a capacidade de gerar receitas, maior a sua sustentabilidade financeira. O CIES ainda depende de doações para a execução de suas atividades, por isto está no quadrante inferior. Quanto maior o foco na base da pirâmide, maior é o comprometimento do negócio em atender o público foco dos negócios sociais. $\mathrm{O}$ CIES também apresenta uma situação diferenciada neste eixo, visto que apresenta atendimento exclusivo para a população de baixa renda, diferente dos demais negócios. No caso da Sorridents, esta é a empresa que tem maiores receitas, mas não tem exatamente a preocupação de atender somente a base da pirâmide. 


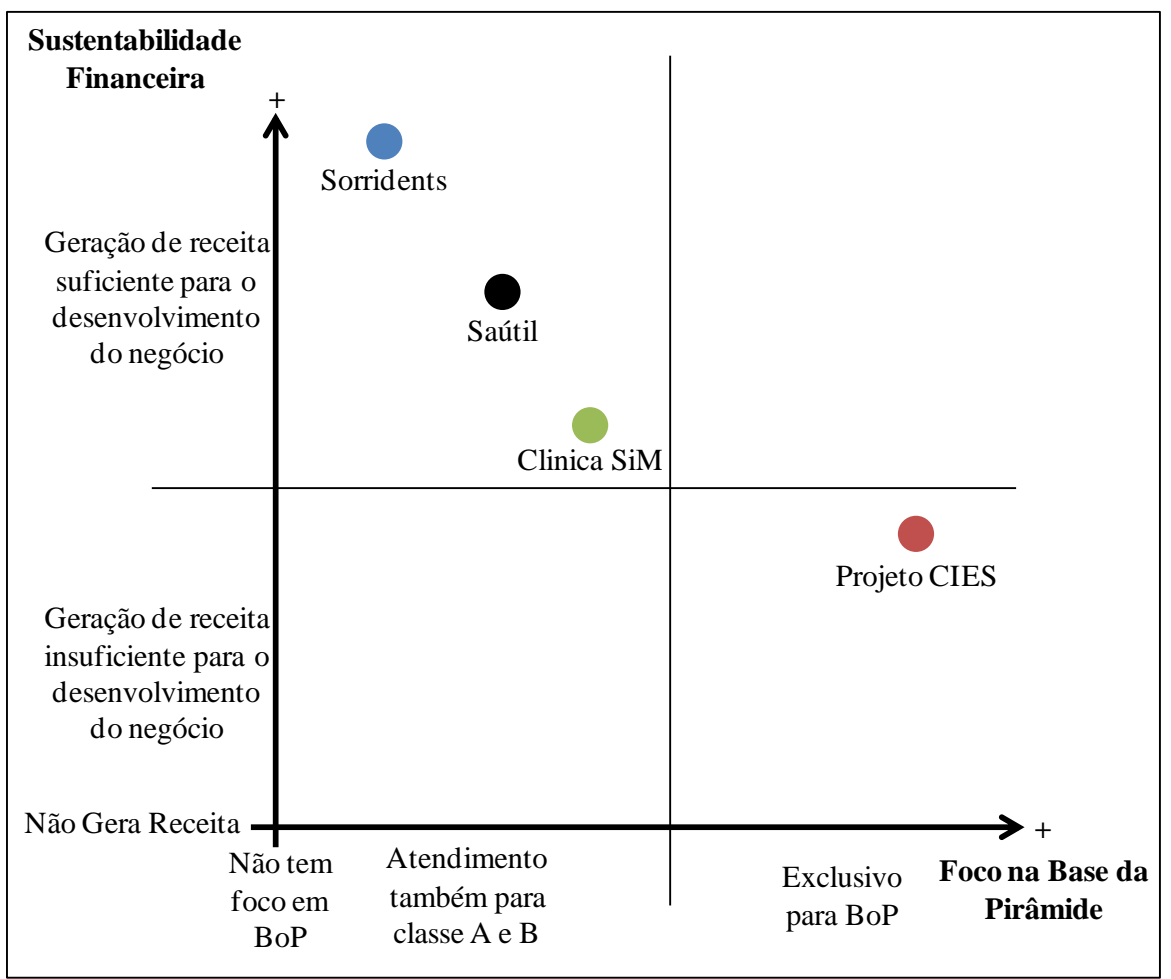

Figura 4: Distribuição dos negócios estudados em relação aos eixos dos Negócios Sociais.

Apesar das diferenças, todos os negócios estudados estão inseridos no ecossistema de negócios sociais, tendo relações com as entidades transversais como aceleradoras e investidoras. Outra característica semelhante é a presença do fundador na gestão e operação dos negócios, mesmo após receber investimento em alguns casos, o que fortalece a conservação dos propósitos da iniciativa, reduzindo a necessidade de indicadores para isso.

Conforme dito acima o posicionamento da CIES é destacado por ultrapassar a barreira de exclusividade de atendimento à Base da Pirâmide e está pouco abaixo da linha referência da Sustentabilidade Financeira por ainda depender de $15 \%$ da receita de doações. O quadrante superior esquerdo contém os outros negócios estudados, já que todos realizam atendimento para outras classes sociais e já possuem geração de receita própria. A posição da Sorridentes é destacada, pois é mais flexível em relação aos atendimentos e ao controle do mesmo e por ser a empresa com a geração de receita mais constante.

O Saútil e a Clinica SIM, apresentam situações muito similares. Entretanto, o Saútil tem um plano de receitas mais consistente e uma estrutura de custos menor e mais flexível, o que torna a sustentabilidade financeira menor e portanto acima da Clínica SIM. Em contraponto, a 
Clínica SIM apresenta controles mais robustos de atendimentos e uma visão mais clara quanto ao uso de seus serviços. Assim como disse a entrevistada: "O público A e B, só é admitido para preencher as lacunas nos horários das consultas". Ou seja, vagas para parceiros fora do público alvo são abertas quando há ociosidade na clíinica.

Pode-se dizer que os negócios estão no momento em que as metas financeiras estão sendo alcançadas ou estão próximas de serem atingidas, e que há uma clara preocupação em avançar no sentido de medir o impacto gerado. Entretanto, esse tema será tratado de forma diferente por cada um dos negócios estudados, conforme o Quadro 10.

Quadro 10 - Síntese dos indicadores de gestão de valor social

\begin{tabular}{|c|c|c|c|}
\hline Empresa & Métricas utilizadas & Status de implantação & $\begin{array}{c}\text { Objetivos do uso de } \\
\text { indicadores sociais }\end{array}$ \\
\hline Saútil & $\begin{array}{c}\text { Perfil do usuário, quantidades } \\
\text { de buscas e sucesso ao } \\
\text { encontrar a informação } \\
\text { desejada. }\end{array}$ & $\begin{array}{c}\text { Implantação do GIIRS e } \\
\text { desenvolvendo um painel } \\
\text { de métricas próprias. }\end{array}$ & $\begin{array}{c}\text { Garantir o foco no atendimento } \\
\text { da população de baixa renda. }\end{array}$ \\
\hline Projeto CIES & $\begin{array}{c}\text { Quantidade de Atendimentos. } \\
\text { Redução do tempo de espera } \\
\text { para realização de exames. }\end{array}$ & $\begin{array}{c}\text { Indicadores próprios, com } \\
\text { relatório estabelecido em } \\
\text { formato próprio. }\end{array}$ & $\begin{array}{c}\text { Monitoramento da melhoria } \\
\text { proporcionada às pessoas que } \\
\text { seriam atendidas pelo SUS. }\end{array}$ \\
\hline Sorridents & $\begin{array}{c}\text { Quantidade de Atendimentos. } \\
\text { Tipo de atendimento } \\
\text { realizado. }\end{array}$ & $\begin{array}{c}\text { Indicadores próprios em } \\
\text { desenvolvimento. }\end{array}$ & $\begin{array}{c}\text { Demonstrar e aprimorar as } \\
\text { iniciativas sociais da empresa. }\end{array}$ \\
\hline Clínica SiM & $\begin{array}{c}\text { Tempo de espera para } \\
\text { realização dos exames. } \\
\text { diagnósticos de doenças que } \\
\text { necessitam de tratamento } \\
\text { rápido utilizado. }\end{array}$ & $\begin{array}{c}\text { Métricas mais focadas } \\
\text { estão sendo estudadas. }\end{array}$ & $\begin{array}{c}\text { Garantir que pessoas estano } \\
\text { sendo atendidas com qualidade } \\
\text { e com velocidade por um preço } \\
\text { justo. }\end{array}$ \\
\hline
\end{tabular}

Como é possível perceber, há diferenças entre cada um dos negócios referentes ao estágio de desenvolvimento sobre a visão dos indicadores financeiros e sociais. O foco são em métricas de outputs, em dados que avaliam a operação, indicadores típicos de empresas convencionais que atuam nos setores estudados. E mesmo que dados mais precisos sobre geração de valor social sejam avaliados, como perfil, melhoria em relação ao serviço prestado ou disponível, estes tópicos, conforme comentado pelos próprios entrevistados, ainda é um assunto que deve evoluir consideravelmente para que atenda às necessidades das empresas.

Entretanto, é necessário que esses dados sejam utilizados na gestão do valor social, dentro de um padrão de formalização em estudos e relatórios e como geram ações diretas para que o 
impacto social seja amplificado, conforme será mais detalhado na Figura 5. Para isto, foi utilizada a escala proposta na metodologia deste trabalho, conforme Figura 3. Para demonstrar graficamente, na Figura 5, os diferentes estágios de cada uma das organizações estudadas, onde é possível notar o nível de desenvolvimento dos indicadores.

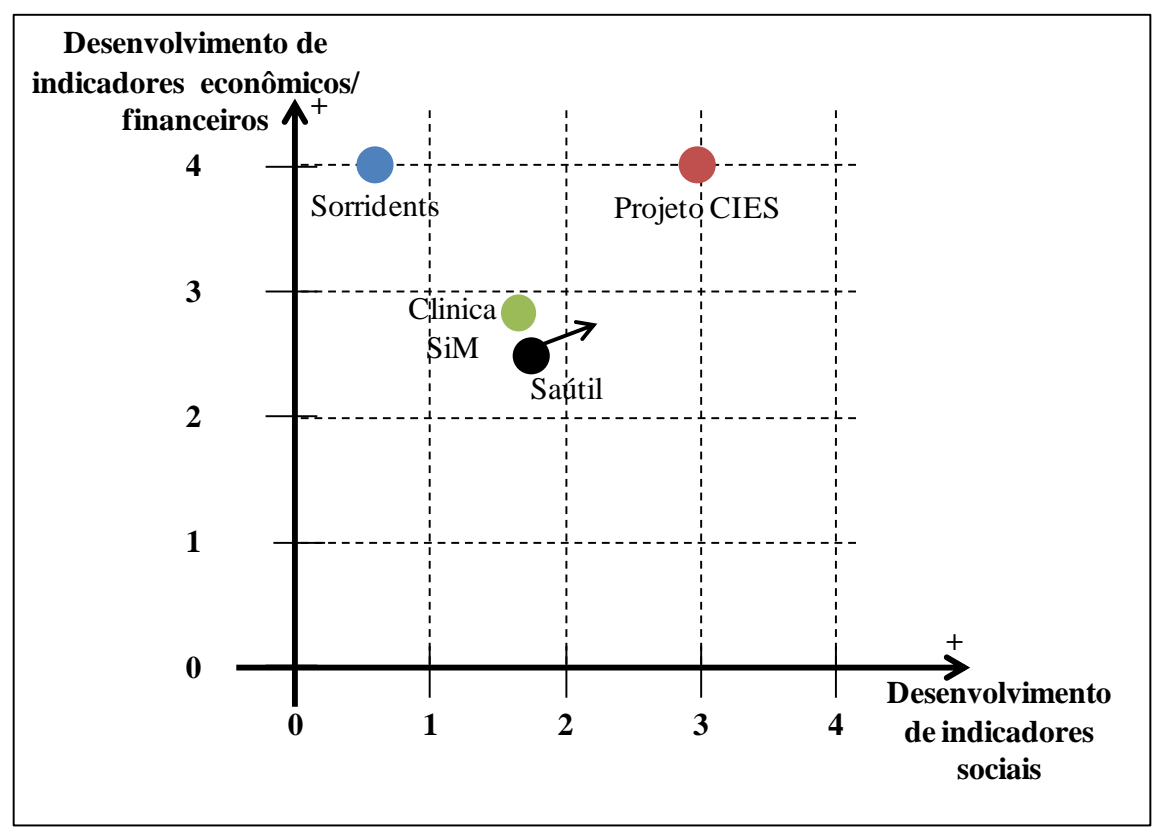

Figura 5: Visão dos casos em relação ao acompanhamento de indicadores sociais e financeiros.

De acordo com os dados coletados, os casos estudados mostram níveis diferentes de desenvolvimento em relação aos indicadores de valor social. Fica evidente também que isso independe do tempo em que o negócio está em operação. A Sorridents, por exemplo, que é a empresa mais antiga, é a que menos está estruturada nos indicadores de valor social. Essa preocupação da evolução fica muito mais ligada à prioridade que o negócio dá a estes indicadores e a como isto influencia nas decisões.

As interações com os atores do ecossistema provocam a implantação de indicadores mais consistentes, como é o caso da Saútil, que, por conta do investidor, aproxima-se de padrões internacionais e realiza um estudo mais profundo na definição das métricas próprias. Ou no caso do CIES, em que uma organização os ajudou a definir indicadores relevantes e a efetivamente realizar a mensuração destes, uma tarefa que requer tempo e competências, e um dos principais entraves da evolução deste tema para a Clínica SiM. 
Reforçando a interação com os atores do ecossistema como indutor do uso e grau de desenvolvimento dos indicadores de valor social, o CIES, que provém de uma organização de terceiro setor, em que as métricas de impacto social são necessárias para se conseguir recursos e para mostrar transparência (CALIL, 2012), tem a situação mais desenvolvida entre os casos estudados em relação a indicadores de impacto social. O CIES apresenta de forma organizada (em um "Relatório Anual"), as informações que são coletadas desde 2007, além de um estudo mais profundo sobre os benefícios gerados pelas suas ações aos usuários do SUS. Provavelmente, estes são dados construídos e organizados, posto que os parceiros (como os doadores de equipamentos e do caminhão) necessitam destes para poder executar a parceria.

A Sorridents, por sua vez, tem uma visão de impacto social muito vinculada a suas ações de responsabilidade social corporativa, uma vez que se relaciona em um ecossistema mais convencional, em que um prêmio de reconhecimento por suas ações sociais é mais valorizado que o acesso ao tratamento gerado.

Os objetivos dos indicadores sociais são variados também, mesmo que todos demonstrem claramente que querem aumentar o impacto gerado. No CIES e na Clínica SiM há uma preocupação com a qualidade de atendimento, mas, principalmente, se os resultados mostram a evolução no atendimento dos pacientes que precisam de alternativas. Para o Saútil, a preocupação, por ser uma ferramenta disponível a todos com Internet, é se esta está sendo acessada por quem realmente precisa. Já na Sorridents, a visão de melhoria está na padronização dos dados coletados sobre as ações sociais que realiza.

\subsection{Visões do ecossistema}

De acordo com o que foi levantado nas entrevistas com as empresas atuantes no ecossistema de negócios sociais brasileiros, a gestão e o acompanhamento dos indicadores são relevantes, mas não são determinantes para que os negócios recebam suporte de aceleração ou investimentos, desde que no modelo de negócio o impacto social esteja claro e dentro das atividades principais das empresas. Isso não significa que eles não estejam preocupados com a mensuração desses indicadores. 
Empresas de investimento de impacto são possivelmente as mais preocupadas com a gestão, com a transparência e com a divulgação dos resultados. No entanto, a visão do entrevistado, Gilberto Ribeiro, da Vox Capital, é de auxiliar as empresas investidas na construção de um "set de monitoramento", e não de procurar empresas que necessariamente já apresentem os indicadores construídos, por entender que estas não utilizam essas métricas para realizar a gestão de seus negócios nos primeiros momentos.

A empresa analisada - Vox Capital - usa um método estruturado para entender qual o impacto que o investidor procura, como este deve ser mensurado, como deve ser monitorado e como deve ser reportado.

Os aportes são feitos com base na tese de investimentos setoriais, que no caso da saúde para Vox Capital é focado em: a) acesso à informação; b) qualificação da oferta pública; e c) complementação do serviço público (seguros-saúde, clínicas populares, entre outros), focados prioritariamente nos públicos de primeira necessidade: idosos, crianças e mulheres. Dessa forma, o fundo é capaz de realizar uma primeira análise, chamada de screening das muitas empresas que desejam receber investimento. Se a empresa consegue gerar soluções para estes problemas com capacidade de atender muitas pessoas e focado na Base da Pirâmide, são feitas análises de investimento mais detalhadas.

Essas análises são cuidadosamente realizadas, seus métodos são rigorosamente embasados em teorias acadêmicas como a do conceito de ativos divididos em capital físico, social, financeiro e humanos por Moser (2009), além de serem realizadas projeções econômicas, financeiras e operacionais.

Após essas etapas, a empresa na qual a Vox Capital decide investir passa a desenvolver em conjunto com a investidora o "Set de Monitoramento", para que este atenda às necessidades de transparência exigidas pelos investidores. Esse painel de controle é construído utilizando padrões do GIIRS, indicadores do IRIS e métricas próprias. O IRIS é utilizado por disponibilizar propostas de indicadores que são mais padronizados, uma vez que tendem a ser adotados por um maior número de negócios. No entanto, isso não é suficiente para mensurar características particulares de alguns negócios e, portanto, exigem uma leitura mais individualizada e a criação de métricas próprias. 
As métricas próprias são feitas em um processo mais focado no negócio, no tipo de produto e/ou serviço e na forma de interação e relacionamento com o público de base da pirâmide que atende. Esse processo identifica indicadores quantitativos e qualitativos, dos inputs, outputs, outcomes e de impacto que são essenciais, dentro da visão do investido, para identificar pontos de ação na gestão destes negócios e corrigir eventuais desvios, de forma que não se torne uma atividade burocrática, mas sim uma forma de apoio importante para as decisões da empresa.

O GIIRS é a forma aceita hoje entre a maioria dos investidores de impacto para mensurar a efetividade da geração de valor social dos negócios que estão recebendo investimento. No caso da Vox Capital, este indicador tem ainda mais uma finalidade, a de determinar a remuneração do fundo. Este propõe, diferentemente de fundos convencionais, a atrelar não somente o resultado financeiro, mas também a nota agregada do Portfólio medida dentro dos padrões do GIIRS. Por conta disso as empresas investidas devem ser monitoradas dentro desses padrões.

Apesar de o processo ser detalhado e estruturado, ainda é muito interligado ao GIIRS, um sistema que busca padronizar e tornar comparável o impacto gerado por negócios, mas que ainda está muito longe de ser considerado como uma ferramenta efetiva de mensuração e comparação de geração de valor social. Gilberto Ribeiro, da Vox Capital, tem plena consciência disso e citou que o "McDonald's pode ter nota máxima no GIIRS", quando comentava da subjetividade e da necessidade de melhoria desta ferramenta.

$\mathrm{Na}$ entrevista com o Diretor da Aceleradora de Negócios da Artemisia, Renato Kiyama, a abordagem sobre indicadores mostra traços comuns ao que é feito pela Vox Capital. Também não há exigência de que o negócio a ser acelerado já tenha um painel de indicadores formalizado, estruturado, utilizado na gestão do negócio. O que é levado em consideração é: como o problema atacado é adequado à tese construída pela organização de fomento, a capacidade do empreendedor, seu comprometimento com a geração de impacto, a escalabilidade e factibilidade da ideia.

A tese de aceleração da Artemisia é construída através de pesquisas que são feitas nas segmentações de saúde, educação, habitação e mecanismos financeiros. Nessas pesquisas são identificados os principais pontos de necessidade das pessoas da Base da Pirâmide em relação 
a cada um desses temas. São analisadas as falhas no sistema que podem ser foco de atuação de empresas privadas, considerando o que já é oferecido pelo estado e dentro do que é permitido pela legislação específica da área.

Para a saúde, a Artemisia foca em empresas que atuem, principalmente, em: acesso à informação, automação, consultoria de custos e gestão hospitalar, eHealth/mHealth, acesso às consultas médicas/saúde bucal e exames diagnósticos.

A Artemisia trabalha com uma meta de portfólio de empresas aceleradas. Essa meta é dividida entre a financeira, medida pela quantidade de investimento conseguido para os negócios acelerados, e a geração de valor social, medida por meio de critérios desenvolvidos pela organização.

"A mensuração do impacto é mais complexa que a financeira", diz Renato Kiyama. Por conta disso e do comprometimento com o aumento do impacto pós-aceleração, a Artemisia usa um método próprio e mede o impacto antes do período de aceleração, logo depois do período e seis meses depois de terminada a experiência. Essas análises são utilizadas para medir a efetividade do programa de aceleração, e não necessariamente são utilizadas pelo negócio.

As métricas utilizadas estão contempladas no objetivo principal da empresa, no quanto a solução apresentada modifica a vida do cliente final. "Há impacto mais profundo e menos profundo" diz Renato Kiyama, ou seja, há soluções que mudam mais a vida das pessoas que outras, e desta forma recebem um valor diferente na análise feita pela Artemisia, conseguindo assim construir uma forma de comparação entre os negócios e também identificar o quanto contribuíram para aumentar o impacto. Esta métrica também é utilizada para mostrar para os investidores da Artemisia os resultados alcançados.

O entrevistado explica que a organização de fomento, ou acelerador, não está inserida no negócio, como um investidor, nem assume posições executivas, portanto, não tem a legitimidade de impor métricas ou determinadas ações. "Este não é o papel da Aceleradora", portanto, a função da organização se restringe a estimular que a empresa pense nesse sentido e que melhore a forma como direciona suas escolhas, levando em consideração os aspectos sociais. Em compensação, "este é um papel do investidor" na análise de Renato Kiyama, 
porque além de os investidores terem poder de influência sobre as empresas, precisam de indicadores e metas para analisar a alocação de seus recursos.

No entanto, a discussão mais profunda com estes atores do ecossistema (investidores e aceleradores) é a real necessidade da utilização de métricas para os empreendedores. Tanto Gilberto da Vox Capital, quanto Renato Kiyama, da Artemisia, acreditam que os empreendedores têm de ter poucos indicadores, e somente aqueles que os ajudem a gerir seus negócios, ou apenas os indicadores que garantam que estão "resolvendo o problema do cliente e sobrevivendo", como definiu Renato.

No estágio inicial das empresas, foco de atuação de ambas as organizações, os empreendedores não conseguem, por falta de recursos, tempo, foco e necessidade, em alguns casos, realizar a gestão de indicadores de valor social, e se para os indicadores econômicos eles conseguem, é por uma questão de legislação ou mesmo de necessidade de gerir o fluxo de caixa.

Renato Kiyama acredita que a mensuração do que passou pouco ajuda os novos negócios: “este não é o problema”, diz. Ele pensa que para os negócios terem consciência de seu impacto e a certeza de que estão tomando as decisões para ampliar este resultado, precisam ter uma visão estruturada sobre o problema. No caso da Saúde, o empreendedor tem que entender que tipo de serviço está oferecendo e que problemas este serviço está resolvendo, de forma pragmática. A Vox Capital compartilha com parte dessa visão, porque acredita que métricas mais estruturadas ajudam o foco na maximização da geração de valor social, mas concordam que o empreendedor tem que saber a que tipo de resultado ele quer chegar, qual impacto ele quer entregar. Portanto, o problema maior parece estar na definição de objetivos e as métricas seriam apenas uma ferramenta para ajudar nisso.

As duas instituições divergem parcialmente sobre a aplicação de ferramentas como GIIRS e IRIS, enquanto a Aceleradora, apesar de entender a importância destas para os investidores, acredita que as comparações provocadas pelo uso desses padrões são irreais e pouco úteis. Os investidores acreditam que mesmo precisando de melhorias é o meio usual e legitimado de comparar negócios e fundos focados na geração de valor social. 


\section{CONCLUSÃO}

\subsection{Adequação às definições de negócios sociais}

Conforme apresentado nos casos, as empresas estudadas têm como foco ações que buscam trazer soluções e gerar parte da liberdade individual defendida por Sen (2010), uma vez que trabalham objetivamente para oferecer à população da base da pirâmide serviços médicos, ao atuarem na eliminação de privações e promoverem o aumento de escolhas no acesso à saúde. Além desse tipo de atuação, essas empresas têm claramente a intenção de manter a condição de sustentabilidade financeira, realizando a atividade foco de suas instituições. Portanto, pode-se dizer que se enquadram na definição de negócios sociais escolhida neste trabalho e proposta por Comini et al. (2011), por atuarem dentro de uma lógica de mercado gerando valor social.

$\mathrm{Na}$ perspectiva de outros autores e organizações, os negócios sociais estudados não se enquadram completamente na perspectiva europeia EMES (COMINI et al., 2011), que define que o interesse material dos investidores capitalistas deve ser limitado. Além disso, a perspectiva europeia tem uma preocupação muito maior com o rigor da governança e com a participação das partes interessadas (DEFOURNY; NYSSENS, 2012).

Pela perspectiva de Young (2009), as empresas estudadas seriam consideradas empresas híbridas, uma vez que focam na geração de benefícios sociais claros e na remuneração dos stakeholders. E, além disso, mostram-se alinhadas com a perspectiva americana de buscar aumento de escala para se tornarem viáveis e aumentarem o impacto proporcionado. $\mathrm{O}$ exemplo mais claro é o da Sorridents, que possui uma extensa rede de franquias, e o do Saútil, por ser uma ferramenta web que tem grande capacidade de oferecer os serviços para muitos usuários. O CIES e a Clínica SiM estão em estágio diferente, já que ambos estão em busca do modelo de expansão ideal para suas atividades, apesar de, claramente, terem necessidade de crescer.

Dos negócios estudados, nenhum deles inclui, por uma questão de política clara, pessoas de baixa renda como fornecedores ou produtores, conforme uma das visões possíveis (MÁRQUEZ; REFICCO; BERGER, 2010). Também não estão alinhados com a definição de "negócios inclusivos", utilizada por algumas organizações, por não terem o foco de geração 
de oportunidades de emprego e renda para grupos com baixa ou nenhuma mobilidade no mercado de trabalho. No entanto, ainda se enquadram na definição abrangente utilizada pela SEKN.

Segundo a definição de Yunus (2010), em que o lucro deve ser utilizado para reduzir ainda mais a pobreza, apenas o CIES possui esta visão de maneira clara. As demais empresas estudadas não se enquadram claramente nesta visão, principalmente a Sorridents, que possui a visão mais conectada com o crescimento e com a atratividade pela geração de resultados financeiros.

Como é possível verificar, as diferentes definições possibilitam visões diversas dos negócios estudados e em seu enquadramento como "Negócio Social". O Brasil ainda se encontra longe de uma visão de legislação, como acontece nos EUA e Europa, e as tentativas de certificações, como é o caso da B-Corporation, mostram-se insuficientes para se chegar a uma separação unanime entre negócios sociais e convencionais.

Esta falta de uma definição clara sobre o conceito de negócios sociais é algo que deve ser aprofundado e amadurecido, visto que o conceito ainda é novo e é importante nomenclatura (DEES, 1998) e definição claras para que o estudo sobre o tema seja delimitado e objetivo, além de aproximar os atores envolvidos. Contudo, vale retomar que a definição não deve ser rígida, mas algo abrangente e unificado (FUNDAÇÃO AVINA; POTENCIA VENTURES; ASPEN NETWORK OF DEVELOPMENT ENTREPRENEURS POLO BRASIL, 2011).

\subsection{Visão de indicadores pelo ecossistema}

Os atores do ecossistema brasileiro analisados nesta pesquisa envolvem, principalmente, os empreendedores e negócios apoiados e/ou envolvidos com os dois atores de fomento deste ecossistema que foram entrevistados: a Artemisia e a Vox Capital. A Sorridents não recebeu investimento nem apoio de aceleração dos atores mencionados do ecossistema, entretanto, já teve contato com ambos em seus processos seletivos. Mas por ser um negócio em estágio mais avançado, com o modelo de negócios consolidado, com o processo de expansão definido e com muitas possibilidades de captação de capital, não foi enquadrado dentro desses programas. 
A aceleradora da Artemisia e a Vox Capital são exemplos de organizações "pivô" e, portanto, têm como um de seus papéis promover o desenvolvimento do ecossistema, assim como das organizações que o constituem (REFICCO; VERNIS, 2010). Uma das formas é gerar maneiras de mostrar que os objetivos do setor estão sendo alcançados, ou seja, que as empresas e os outros atores estão gerando rentabilidade e benefícios sociais.

A Vox Capital faz isso utilizando indicadores padronizados (GIIRS e IRIS) e estimulando o uso dessas ferramentas de transparência e divulgação pelos negócios, e, de certa forma, cumprindo o papel de certificar as empresas que apoia (FERRARY; GRANOVETTER, 2009). No entanto, esta visão ainda é controversa, devido ao baixo grau de precisão que essas ferramentas apresentam. De qualquer forma, é um forte estímulo ao uso de indicadores.

Já a Aceleradora de Negócios, por conta do papel de suporte aos negócios, sem ser responsável pela gestão, controla com indicadores desenvolvidos pela própria organização o desempenho econômico e social dos negócios acelerados. Além disso, estimula que esses negócios façam a gestão das métricas da melhor maneira possível, desde que isso não tire o foco de manter o negócio funcionando e com a sustentabilidade financeira como prioridade.

A aceleradora considera que primeiramente a empresa deve focar nos resultados financeiros e depois pensar em ampliar o impacto. Ou seja, primeiro deve ser financeiramente sustentável e desta forma cumprir a missão de gerar valor social. Isso se deve à situação inicial dos negócios apoiados, que estão em seus primeiros passos e enfrentam grandes desafios para sobreviver.

A discussão levantada pelos atores do ecossistema sobre como realizar a escolha dos indicadores, como realizar o acompanhamento e gestão dos negócios sociais, levanta uma série de questões que não são integralmente respondidas e que devem ser aprofundadas em futuros estudos. São perguntas como: quais indicadores são realmente importantes para cada negócio, ou qual a metodologia para se chegar a eles, como balancear as atividades com o controle de indicadores, como construir um padrão de métricas e se isto é algo realmente necessário. 
Seguindo a divisão entre a ótica de empreendedores e investidores, conforme as necessidades de cada um, é possível constatar pelas entrevistas que os investidores são os mais afetados pela ausência dos indicadores. Isso ocorre porque são os atores que dependem integralmente desses dados para exercer seu papel de captar recursos, demonstrar resultados e conseguir realizar novos aportes. Portanto, os indicadores devem ser consistentes e comparáveis, e devem demonstrar credibilidade e rastreabilidade. Para as empresas, os indicadores são importantes, mas não estão na lista de prioridades, já que o negócio se desenvolve sem as métricas. Já para a aceleradora, essa importância está mais concentrada como avaliação do resultado do processo de apoio.

Dada a importância do ecossistema na sustentabilidade financeira, e considerando os casos estudados, ficou claro que existe uma compensação entre geração de receita e foco na população de baixa renda. O CIES, por exemplo, ainda possui parte da receita provenientes de doações, mas em contrapartida possui dedicação mais exclusiva ao seu público-alvo. Avaliar a utilização de doações nos negócios sociais torna-se ponto pertinente a novos estudos, porque se, por um lado, isso traz riscos de instabilidade de captação de recursos e uma dependência externa, por outro, pode possibilitar que os negócios sociais consigam se desenvolver sem realizar atendimento a outro tipo de público, no momento inicial, sem que o conceito de sustentabilidade financeira seja perdido.

Outra questão que deve ser estudada com mais detalhes são as relações dos negócios sociais com outros atores dos ecossistemas, como: governo, agências reguladoras, universidades, laboratório de pesquisas, empresas prestadoras de serviços e mídia, e como os indicadores influenciam esta relação e podem ser utilizados para melhorar e estreitar as interações.

\subsection{Desafios e barreiras}

Apesar de todos os entrevistados acreditarem que a adoção de indicadores garante a credibilidade, melhoria e clareza nas tomadas de decisão, nem todos tratam o tema como prioritário (CALIL, 2012). A principal deficiência encontrada é como combinar homogeneamente as métricas de geração de receita com os benefícios sociais, conforme preconizado por Bugg-Levine e Emerson (2011). 
A escolha de indicadores deve ser cuidadosa. Devido ao conceito reducionista de traduzir um evento por meio de métricas e da dificuldade que esta ação implica, mesmo com a ajuda de proxys ou metodologias complexas, a tarefa de criar métricas corretas, que realmente capturem o que se deseja pode ser muito trabalhosa, conforme relatado pelas empresas entrevistadas (CALIL, 2012). Portanto, em muitos casos, é necessário refletir e balancear o quanto esta métrica ajuda o negócio, levando em consideração seu estágio de desenvolvimento e o quanto esta métrica tira o foco da ação para a mensuração.

Um exemplo dentro dos casos é o Saútil, que para medir se a pessoa realmente consegue pegar o medicamento tem que criar novos processos, enquanto o impacto de disponibilizar a informação foi gerado. Ou seja, cada empresa deve estruturar seus indicadores considerando a dificuldade e importância da informação gerada. Na visão da Artemisia, a mensuração deve ser mais conceitual, de forma que seja prática e rápida, no entanto, isso torna o indicador menos credível e mais subjetivo. Essa afirmação, em conjunto com os dados coletados, leva à conclusão que a intenção do negócio não é refletida no cuidado com as métricas.

As limitações do estudo também não trazem respostas quanto as principais necessidades que o ecossistema de negócios sociais precisa para evoluir mais rapidamente e com consistência em seus resultados financeiros e sociais. Os estudos dos casos trazem pistas sobre a necessidade de maior interação com organizações de apoio, que promovem, além do uso de indicadores, uma consistência maior quanto à sustentabilidade financeira, desenvolvimento dos negócios e aumento do impacto gerado.

Uma das dificuldades do setor, conforme visão do Diretor da Aceleradora de Negócios da Artemisia, é encontrar e/ou estimular que mais empreendedores estejam focados em desenvolver soluções para problemas sociais que envolvam a base da pirâmide e que sejam capazes de construir um modelo de negócio que resolva este problema e gere receita para que a solução seja consistente e atinja um número maior de pessoas.

Mais investimentos são necessários, na visão de empreendedores e dos atores do ecossistema entrevistados, entretanto, parte deles acredita que o modelo de investimento deve ser aprimorado, para que seja capaz de investir em negócios que gerem mudanças mais estruturais e maiores no sistema. Uma frase do fundador do eBay (Pierre Omidyar) citada pelo Diretor da Aceleradora da Artemisia é que "As empresas de tecnologia geraram mais 
impacto que todos os negócios sociais”. Essa frase reforça a ideia de que é necessário encontrar e comprar o risco de negócios que podem gerar mudanças maiores e menos mudanças incrementais em relação ao valor social gerado por todos do ecossistema.

\subsection{Importância do ecossistema}

A principal conclusão que é extraída dos dados pesquisados é que os indicadores são utilizados na medida em que o ecossistema exige deles (REFICCO; VERNIS, 2010). Ou seja, nos casos estudados, pode-se dizer que o CIES é a empresa mais estruturada em termos de indicadores. Isso provavelmente se deve ao fato de ser uma empresa com origem em um projeto social e que conta com parceiros para realizar suas atividades. Portanto, essa tem, obrigatoriamente, de mostrar dados que confirmem suas ações, o valor social gerado e a sua condição financeira de maneira transparente e credível para conhecimento dos parceiros.

A Saútil se destaca pela sua intenção de criar um painel de controle que ajudará a demonstrar o impacto social gerado e utilizado para maximizá-lo. Essa evolução é fruto da ação do investidor, que além de preparar a empresa para se enquadrar no GIIRS e utilizar métricas IRIS, auxilia a criar uma estrutura de indicadores que permita gerir os inputs, outputs, outcomes e impacto (OLIVEIRA FILHO, KIYAMA; COMINI, 2011). Isso mostra como o resultado da ação dos investidores é importante para viabilizar tal análise;

No caso da Sorridents, vê-se que existe uma estruturação típica de indicadores de uma organização odontológica. Ou seja, possui bons dados de informações financeiras, mas indicadores sociais são utilizados para medir o impacto de ações de responsabilidade social e não de sua atividade fim voltada para a população de baixa renda, mostrando dados das ações de forma segmentada da operação do negócio. No ecossistema de relacionamento da Sorridents, essas informações são suficientes para que ela receba prêmios de sustentabilidade e estimule a expansão e o sucesso de seu sistema de franquias.

A Clínica SiM não apresentava, até o momento da entrevista, sistematização de seus indicadores e métricas de geração de valor social, limitando-se aos indicadores que fortalecem sua sustentabilidade operacional e financeira. Como está em um momento de expansão e enxerga nos médicos uma fonte consumidora de dados sociais e financeiros, a empresa se 
planeja para começar a atuar com mais precisão sobre os indicadores, mas ainda tem dificuldades para conseguir direcionar recursos para estas atividades.

Segundo a análise, o papel das organizações de apoio para promover o uso de indicadores é muito importante, entretanto, é preciso salientar que a preocupação e o uso dos indicadores corretos que auxiliem na gestão devem estar presentes, desde que estejam integrados com os objetivos da empresa. A partir dos casos demonstrados não conseguimos dizer que a falta de painel de controle, sobretudo de indicadores de valor social, causam desvio de trajetória em relação às metas iniciais e uma possível perda de valor social. Fato que deve ser aprofundado.

Devido ao caráter exploratório desta pesquisa, foram identificados alguns pontos em comum nos casos estudados. A importância da exigência do ecossistema para que as organizações superem as dificuldades de mensuração de resultados, utilizando critérios definidos e o suporte na construção dos indicadores, está acima da intenção e da preocupação do negócio em gerar impacto social. Ou seja, a utilização de métricas está mais conectada com as imposições do ecossistema do que com a intenção do empreendedor.

Por outro lado, pela limitação desta pesquisa e pelo estágio inicial do ecossistema e dos negócios sociais estudados, não foi possível identificar diferenças trazidas e benefícios pelos negócios que estão mais avançados no tema de gestão de indicadores de geração de valor social. Ou seja, é necessário avaliar se as empresas com intenção e comprometimento em gerar valor social, que não utilizam métricas, vão aperfeiçoar sua geração de valor, tanto quanto uma empresa que possui estruturação nos indicadores por conta das necessidades impostas por outros atores do setor.

\subsection{Recomendações}

Foi possível identificar, pelas entrevistas, que os próprios indicadores, padrões e metodologias existem e são considerados relevantes para as organizações, mas ainda necessitam de evolução para que se tornem ferramentas capazes de clarificar quanto cada negócio social gera de valor social e como isso é utilizado na gestão, a fim de que o impacto seja mantido e ampliado sem reduzir a sustentabilidade financeira. 
Toda organização, sendo um negócio social ou não, precisa constantemente rever seus indicadores; dessa forma, é possível entender que cada um dos negócios pode evoluir em relação ao desenvolvimento de métricas. O caso CIES foi o que demonstrou maior nível de desenvolvimento em relação às métricas sociais. Recomenda-se aprofundar algumas análises de aspectos sociais para que os dados levem ao uso mais imediato de decisões na gestão do negócio.

Uma evolução possível para o caso da Clínica SiM é a padronização dos indicadores utilizados, porque foram realizados diversos estudos que demonstram informações importantes, tanto do lado do valor social quanto do econômico. Porém não tiveram continuidade, e é recomendado que os indicadores tenham uma frequência definida para que as informações estejam prontas para suportar as decisões.

No caso dos indicadores econômico-financeiros, a Sorridents possui um bom grau de desenvolvimento. Esta situação não é replicada para os indicadores sociais. A Sorridents ainda não tem um padrão nos indicadores voltados para avaliar o valor social gerado por sua atividade fim. A empresa tem alguns estudos sobre a geração de atendimentos mais acessíveis, entretanto, suas ações direcionadas à população de baixa renda são realizadas pela proximidade física e pela falta de consultórios odontológicos em alguns lugares onde, agora, existem clínicas da Sorridents.

A situação mais particular dos casos estudados é a do Saútil, que por ser uma plataforma online com um serviço inovador, possui indicadores diferentes dos negócios de saúde convencionais, o que exige que a definição de métricas seja mais complexa em relação aos benefícios sociais de sua atuação. Esta questão estava sendo resolvida em parceria com a Vox Capital por meio da construção de um "set de monitoramento", ou seja, uma sistematização dos indicadores para que possam entender o que cada mudança no negócio gera em seu público-alvo, nos outros produtos e dessa forma manter o foco nos resultados desejados.

As métricas de produtividade utilizadas por empresas como CIES, Clínica SiM e Sorridents são muito semelhantes às utilizadas pelas clínicas convencionais. Já o Saútil, tem métricas mais individualizadas que se assemelham a outros serviços de busca. Entretanto, os negócios sociais citados têm a intenção de atender prioritariamente e da forma mais adequada à população de baixa renda, portanto, indicadores sobre estas questões devem fazer parte do 
monitoramento regular das empresas. Possuir dados voltados para o entendimento de como a população de baixa renda está sendo atendida e de como o atendimento a outro tipo de cliente afeta o desempenho do foco principal é uma questão necessária e que todos os negócios devem evoluir. A Clínica SiM e o Saútil precisam entender melhor esta situação de diversidade de público; o CIES poderia ampliar os atendimentos e aumentar a receita com a segurança, que não estará desviando de seu propósito, e a Sorridents poderia saber com mais detalhes a parcela de seus atendimentos que é realizada para cada tipo de população e qual o valor social gerado pela sua atividade fim.

Os quatro negócios mostram oportunidades de melhoria e seriam beneficiados se avançassem na questão dos indicadores, tanto para ter mais ferramentas para tomar decisões, quanto para continuar na direção de solucionar os problemas sociais a que se propõem, sem deixar de gerar receitas suficientes para desenvolverem e expandirem seus negócios. 


\section{REFERÊNCIAS}

ABRAMOVAY, R. Desenvolver os territórios fortalecendo o empreendedorismo de pequeno porte. In: FÓRUM INTERNACIONAL "TERRITÓRIO, DESENVOLVIMENTO RURAL E DEMOCRACIA", 1., 2003, Fortaleza. Anais... Brasília, DF: Instituto Interamericano de Cooperação para a Agricultura, 2003. p. 1-35. Disponível em:

$<$ http://www.fea.usp.br/feaecon//media/fck/File/empreendedorismo_e_desenvolvimento_territ orial.pdf $>$. Acesso em: 18 nov. 2013.

ARTEMISIA. Aceleradora de Impacto: portfólio. Disponível em: <http://www.artemisia.org.br/ace_portfolio.php>. Acesso em: 12 nov. 2012.

ARTUSO, S. B. et al. Empresas sustentáveis geram mais valor aos seus acionistas. In: SEMINÁRIOS EM ADMINISTRAÇÃO, 15., 2012, São Paulo. Anais... São Paulo: Programa de Pós-graduação em Administração da FEA-USP, 2012. p. 1-17.Disponível em:

<http://www.ead.fea.usp.br/semead/15semead/resultado/trabalhosPDF/550.pdf>. Acesso em: 18 abr. 2013.

BERTOLUZZI, M. R.; GRECO, R. M. As políticas de saúde no Brasil: reconstrução histórica e perspectivas atuais. Revista da Escola de Enfermagem da USP, São Paulo, v. 30, n. 3, p. 380-398, dez. 1996. Disponível em:

<http://www.scielo.br/pdf/reeusp/v30n3/v30n3a04.pdf>. Acesso em: 18 abr. 2013.

BISHOP, C. G. Fifty State Series: L3C \& B Corporation Legislation Table. Suffolk

University Law School Research Paper, Boston, n. 10-11, p. 1-57, Feb. 2013. Disponível em: <http://papers.ssrn.com/sol3/Delivery.cfm/SSRN_ID2218817_code737120.pdf?abstractid=15 61783\&mirid=1>. Acesso em: 18 abr. 2013.

BRASIL. Ministério da Saúde. Mais saúde-direito de todos-2008-2011. 4. ed. Brasília, DF: Ed. Ministério da Saúde, 2010. (Série C. Projetos, Programas e Relatórios). Disponível em: 〈http://bvsms.saude.gov.br/bvs/publicacoes/mais_saude_direito_todos_4ed.pdf $>$. Acesso em: 28 nov. 2012.

BUGG-LEVINE, A.; EMERSON, J. Impact investing: Transforming how we make money while making a difference. New York: Jossey-Bass, 2011.

CALIL, L. P. Indicadores: o desafio de evidenciar mudanças. In: OTERO, M. R. (Org.). Contexto e prática da avaliação de iniciativas sociais no Brasil: temas atuais. São Paulo: Peirópolis, 2012. cap. 3.

CALLON, M. Introduction: The embeddedness of economic markets in economics. In:

CALLON, M. (Ed.). The laws of the markets. Oxford: Wiley-Blackwell, 1998. p. 1-57. 
CARDOSO JÚNIOR, J. C.; SANTOS, J. C. Estado e desenvolvimento: instituições e democracia. In: DOWBOR, L.; SACHS, I.; LOPES, C. (Org.). Riscos e oportunidades em tempo de mudanças. São Paulo: Instituto Paulo Freire, 2010. p. 173-182. Disponível em: <http://dowbor.org/blog/wp-content/uploads/2012/06/riscos-e-oportunidades.pdf >. Acesso em: 18 abr. 2013.

CENTRO DE INTEGRAÇÃO DE EDUCAÇÃO E SAÚDE. Conheça o Projeto CIES. Disponível em: <http://www.projetocies.com.br/projeto-cies.php>. Acesso em: 12 nov. 2012.

CHAPIN III, F. S. et al. Principles of terrestrial ecosystem ecology. $2^{\text {nd }}$ ed. London: Springer, 2012.

CLÍNICA SIM. Perguntas frequentes. Disponível em: <http://www.clinicapopularsim.com.br/perguntas-frequentes.php>. Acesso em: 12 nov. 2012.

COMINI, G. Negócios sociais e inclusivos: um panorama da diversidade conceitual. In: RUSCHEL, R. (Ed.). Mapa de soluções inovadoras - tendências de empreendedores na construção de negócios sociais e inclusivos. Barueri: Instituto Walmart/ASHOKA, 2011. p. 7-26. Disponível em: <http://portal.institutowalmart.org.br/arquivos/m/map/mapadeestudos/252_MapaEstudo1Fina lpdf.pdf $>$. Acesso em: 6 set. 2012.

COMINI, G.; BARKI, E.; AGUIAR, L. T. A three-pronged approach to social business: a Brazilian multi-case analysis. Revista de Administração (São Paulo), São Paulo, v. 47, n. 3, p. 385-397, jul./ago./set. 2012. Disponível em:

<http://www.scielo.br/pdf/rausp/v47n3/04.pdf>. Acesso em: 6 set. 2012.

COMINI, G. et al. As promessas dos negócios inclusivos para a pobreza: caminhos e descaminhos da teorização e práxis no contexto brasileiro. São Paulo: Universidade de São Paulo, 2011. Material de aula. Disponível em:

<http://prpg.usp.br/dcms/uploads/arquivos/ppg.afea/EAD-5959.doc>. Acesso em: 6 set. 2012.

DEES, J. The meaning of social entrepreneurship. Boston, MA: Harvard Business School, 1998.

DEFOURNY, J.; NYSSENS, M. The EMES approach of social enterprise in a comparative perspective. EMES Working Papers, Liege, n. 3, p. 1-44, 2012. Disponível em: <http://www.emes.net/uploads/media/EMES-WP-12-03_Defourny-Nyssens.pdf>. Acesso em: 19 set. 2012.

FACULDADE DE MEDICINA DA UNIVERSIDADE DE SÃO PAULO. Sistemas de saúde no Brasil. São Paulo: Ed. FMUSP, [2007]. Disponível em:

<http://fm.usp.br/cedem/did/atencao/4-\%20Bibliografia\%20Complementar\%20$\% 20$ Sistema\%20de\%20Sa\%C3\%BAde\%20no\%20Brasil\%20FINAL.pdf>. Acesso em: 18 nov. 2012. 
FERRARY, M.; GRANOVETTER, M. The role of the venture capital firms in Silicon Valley's complex innovation network. Economy and Society, Stanford, v. 38, n. 2, p. 326359, maio 2009. Disponível em:

<http://www.stanford.edu/dept/soc/people/mgranovetter/documents/FerraryGranovetterEconandSoc5-09.pdf>. Acesso em: 19 set. 2012.

FISCHER, R. M. Desenvolvimento sustentável e empreendimentos sociais. In: PAROLIN, S. R. H.; VOLPATO, M. (Org.). Faces do empreendedorismo inovador. Curitiba: Ed. SENAI-PR, 2008. v. 3, p. 273-308. (Coleção Inova). Disponível em: < ttp://www.pr.senai.br/para-empresas/uploadAddress/volumetres[36098].pdf>. Acesso em: 18 abr. 2013.

FUNDAÇÃO AVINA; POTENCIA VENTURES; ASPEN NETWORK OF DEVELOPMENT ENTREPRENEURS POLO BRASIL. (Coord.). Mapeamento do campo de negócios sociais: negócios inclusivos. São Paulo: Plano CDE, 2011. Disponível em: <http://www.aspeninstitute.org/sites/default/files/content/docs/ande/Mapeamento\%20Neg\%C $3 \%$ B3cios $\% 20$ Sociais_Inclusivos $\% 20$ -

$\% 20$ Relat $\%$ C3\%B3rio\%20final\%20categoria\%20neg\%C3\%B3cios\%5B1\%5D.pdf $>$. Acesso em: 10 jan. 2012.

FUNDACIÓN AVINA. Mercados inclusivos. Cidade de Panamá, 2012. Não paginado. Disponível em: <http://www.avina.net/por/oportunidades/mercados-inclusivos/>. Acesso em: 11 out. 2012.

GLOBAL IMPACT INVESTING NETWORK. About IRIS. Disponível em: <http://iris.thegiin.org/about-iris>. Acesso em: 5 nov. 2012.

GLOBAL IMPACT INVESTING RATING SYSTEM. About GIIRS. Disponível em: <http://giirs.org/about-giirs/about>. Acesso em: Acesso em: 3 nov. 2012.

GLOBAL REPORTING INITIATIVE. About sustainability reporting. Disponível em: <https://www.globalreporting.org/information/sustainability-reporting/Pages/default.aspx>. Acesso em: 3 nov. 2012.

GODOY, A. Introdução à pesquisa qualitativa e suas possibilidades. Revista de Administração de Empresas, São Paulo, v. 35, n. 2, p. 57-63, mar./abr. 1995. Disponível em: <http://rae.fgv.br/sites/rae.fgv.br/files/artigos/10.1590_S0034-75901995000200008.pdf〉. Acesso em: 18 abr. 2013.

HELLMANN, T. Venture capitalists: The coaches of Silicon Valley. In: LEE, C. M. et al. (Ed.). The Silicon Valley edge: A habitat for innovation and entrepreneurship. Stanford, CA: Stanford Business Books, 2000. p. 276-294. Disponível em:

<http://books.google.com.br/books/about/The_Silicon_Valley_Edge.html?id=eK52augjU98C \&redir_esc=y>. Acesso em: 18 abr. 2013. 
INSTITUTO FONTE [para o desenvolvimento social]. A avaliação de investimentos sociais no setor privado. São Paulo, 2009. Disponível em:

<http://www.fundacaoitausocial.org.br/_arquivosestaticos/FIS/pdf/avaliacao_invest_social_pr ivado_2008.pdf>. Acesso em: 2 nov. 2012.

INSTITUTO FONTE [para o desenvolvimento social]. A avaliação de programas e projetos sociais de ONGs no Brasil: relatório de pesquisa. São Paulo, 2010. Disponível em:

<http://institutofonte.org.br/sites/default/files/Relat\%C3\%B3rio_Pesquisa_Avalia\%C3\%A7\% C3\%A3o_Projetos_Sociais_0.pdf>. Acesso em: 2 nov. 2012.

INTERNATIONAL INTEGRATED REPORTING COUNCIL. IIRC resources. Disponível em: <http://www.theiirc.org/about/making-happen/>. Acesso em: 5 nov. 2012.

ISENBERG, D. J. The big idea: How to start an entrepreneurial revolution. Harvard Business Review, Boston, MA, p. 1-11, June 2010. Disponível em:

<http://innomagazine.fundacionbankinter.org/akademia/books/pdfs/HowtostartanEntrepreneu rialRevolution.pdf>. Acesso em: 18 abr. 2013.

KAPLAN, R. S.; NORTON, D. P. The balanced scorecard - measures that drives performance. Harvard Business Review, Boston, MA, v. 70, n. 1, p. 71-79, Jan./Feb. 1992. Disponível em: 〈http://www.iluv2teach.com/mgt424/BS1.pdf>. Acesso em: 18 abr. 2013.

KARNANI, A. The mirage of marketing at the bottom of the pyramid: How the private sector can help alleviate poverty. California Management Review, Ann Arbor, v. 49, n. 4, p. 90-111, Summer 2007. Disponível em:

<http://www.un.org/esa/coordination/Mirage.BOP.CMR.pdf>. Acesso em: 18 abr. 2013.

KERLIN, J. Social enterprise in the United States and Europe: Understanding and learning from the differences. Voluntas: International Journal of Voluntary and Nonprofit Organizations, AA Dordrecht, v. 17, n. 3, p. 246-262, Sep. 2006. Disponível em: 〈>. Acesso em: 18 abr. 2013.

KHANDKER, S. R.; KOOLWAL, G. B.; SAMAD, H. A. Handbook on impact evaluation: Quantitative methods and practices. Washington, DC: World Bank Publications, 2010. (World Bank Training Series). Disponível em: <https://openknowledge.worldbank.org/bitstream/handle/10986/2693/520990PUB0EPI1101O fficial0Use0Only1.pdf?sequence=1>. Acesso em: 18 abr. 2013.

MAGALHÃES, R. S. Lucro e reputação: interações entre bancos e organizações sociais na construção das políticas socioambientais. 2010. 275 f. Tese (Doutorado em Ciência Ambiental) - Universidade de São Paulo, São Paulo, 2010. Disponível em: <http://www.teses.usp.br/teses/disponiveis/90/90131/tde-19082011201545/publico/TeseMagalhaes.pdf>. Acesso em: 18 abr. 2013.

MALHORTA, N. Pesquisa de marketing: uma orientação aplicada. Porto Alegre: Bookman, 2001. 
MÁRQUEZ, P.; REFICCO, E.; BERGER,G. Conclusiones: aprendizajes sobre el desarrollo de negocios inclusivos. In: MÁRQUEZ, P.; REFICCO, E.; BERGER, G. (Ed.). Negocios inclusivos: iniciativas de mercado con los pobres de Iberoamérica. Bogotá: Amaral Editores, 2010. p. 341-377. Disponível em: <http://www.redunes.org/wpcontent/uploads/2012/07/SEKN-Negocios-inclusivos-versi\%C3\%B3n-espa\%C3\%B1ol.pdf>. Acesso em: 18 nov. 2012.

MARTINS, G. D. A. Manual para elaboração de monografias e dissertações. São Paulo: Atlas, 1994.

MARTINS, G. D. A. Sobre confiabilidade e validade. Revista Brasileira de Gestão de Negócios, São Paulo, v. 8, n. 20, p. 1-12, jan./abr. 2006. Disponível em:

<http://www.spell.org.br/documentos/download/6471>. Acesso em: 18 abr. 2013.

MATTAR, F. N. Pesquisa de marketing: metodologia, planejamento São Paulo: Atlas, 1997.

MOORE, J. F. Predatos and prey: A new ecology of competition. Harvard Business Review, Boston, MA, v. 71, n. 3, p. 75-86, May./June 1993. Disponível em:

<http://blogs.law.harvard.edu/jim/files/2010/04/Predators-and-Prey.pdf>. Acesso em: 18 abr. 2013.

OLIVEIRA FILHO, G. R.; KIYAMA, R. S.; COMINI, G. Impacto social. In: BARKI, E. (Org.). Negócios sociais no Brasil. São Paulo: Peirópolis, 2011. No prelo.

OLSEN, S.; GALIMIDI, B. Catalog of Approaches to Impact Measurement: Assessing social impact in private ventures. [S.1.]: Social Venture Technology Group, 2008. Disponível em: <http://svtgroup.net/wp-content/uploads/2011/09/SROI_approaches.pdf>. Acesso em: 18 abr. 2013.

PIOLA, S. F. et al. Vinte anos da Constituição de 1988: o que significaram para a saúde da população brasileira? Políticas Sociais: Acompanhamento e Análise, Brasília, DF, v. 1, n. 17, p. 97-172, 2009. Disponível em: <

http://www.ipea.gov.br/portal/images/stories/PDFs/politicas_sociais/bps_completo_1_7e.pdf> . Acesso em: 18 jan. 2013.

PORTER, M. E. A vantagem competitiva das nações. 7. ed. Rio de Janeiro: Campus, 1989.

PORTER, M. E. Competitive advantage: Creating and sustaining superior performance. New York: Free Press, 1985.

PORTOCARRERO, F. S.; DELGADO, Á. J. Negocios inclusivos y generacíon de valor social. In: MÁRQUEZ, P.; REFICCO, E.; BERGER, G. (Ed.). Negocios inclusivos: iniciativas de mercado con los pobres de Iberoamérica. Bogotá: Amaral Editores, 2010. p. 301-340. Disponível em: <http://www.redunes.org/wp-content/uploads/2012/07/SEKNNegocios-inclusivos-versi\%C3\%B3n-espa\%C3\%B1ol.pdf>. Acesso em: 18 nov. 2012. 
POTENCIA VENTURES; PROSPECTIVA. Estudo sobre oportunidades de negócios de saúde para a população de baixa renda no Brasil. São Paulo: Potencia Ventures, 2012. Material distribuído no Encontro Empreendedores da Rede Artemisia, com o tema Negócios Sociais em Saúde, em 15 jun. 2013, em São Paulo.

PRAHALAD, C. K. The fortune at the bottom of the pyramid: Eradicating poverty through profits. Philadelphia: Wharton School Publishing, 2004.

PZREWORSKY, A. Estado e economia no capitalismo. Rio de Janeiro: Relume-Dumará, 1995.

REFICCO, E.; VERNIS, A. Ecosistemas organizacionales para fortalecer negocios inclusivos. In: MÁRQUEZ, P.; REFICCO, E.; BERGER, G. (Ed.). Negocios inclusivos: iniciativas de mercado con los pobres de Iberoamérica. Bogotá: Amaral Editores, 2010. p. 127-172. Disponível em: <http://www.redunes.org/wp-content/uploads/2012/07/SEKNNegocios-inclusivos-versi\%C3\%B3n-espa\%C3\%B1ol.pdf>. Acesso em: 18 nov. 2012.

SACHS, I. Estratégias de transição para o século XXI. In: BURZTYN, M.; MENDES, A. D. (Org.). Para pensar o desenvolvimento sustentável. Brasília, DF: Brasiliense, 1993. p. 29-56.

SEN, A. Desenvolvimento como liberdade. São Paulo: Companhia das Letras, 2010.

SORRIDENTS CLÍNICAS ODONTOLÓGICAS. Quem somos nós. Disponível em: <http://www.sorridents.com.br/quem-somos/>. Acesso em: 12 nov. 2012.

THE SROI NETWORK. Details for A Guide to Social Return on Investment 2012. Disponível em: <http://www.thesroinetwork.org/publications/doc_details/241-a-guide-tosocial-return-on-investment-2012>. Acesso em: 5 nov. 2012.

TORRES, H. D. G. O papel do setor privado a oferta de serviços sociais para a base da pirâmide. In: BARKI, E. (Org.). Negócios sociais no Brasil. São Paulo: Peirópolis, 2011. No prelo.

VERGARA, S. C. Projetos e relatórios de pesquisa em administração. 6. ed. São Paulo: Atlas, 2005.

WORLD HEALTH ORGANIZATION. Relatório mundial da saúde: financiamento dos sistemas de saúde - o caminho para a cobertura universal. Geneva: WHO Press, 2010. Disponível em: 〈http://www.who.int/whr/2010/whr10_pt.pdf〉. Acesso em: 18 abr. 2013.

WORLD HEALTH ORGANIZATION. World health statistics 2012. Geneva: WHO Press, 2012. Disponível em:

<http://www.who.int/iris/bitstream/10665/44844/1/9789241564441_eng.pdf>. Acesso em: 18 abr. 2013. 
YIN, R. Estudo de caso: planejamento e métodos. 2. ed. São Paulo: Bookman, 2003.

YOUNG, D. R. A unified theory of social enterprise. In: SHOCKLEY, G. E.; STOUGH, R. R.; FRANK, P. M. (Ed.). Non-market entrepreneurship: Interdisciplinary approaches. Cheltenham: E. Elgar Publishing, 2008. p. 175-191.

YOUNG, D. R. Alternative perspectives on social enterprise. In: CORDES, J. J.; STEUERLE, C. E. (Ed.). Nonprofits \& business. Washington DC: The Urban Institute Press, 2009. p. 21-46.

YUNUS, M. Criando um negócio social: como iniciativas económicamente viáveis podem solucionar os grandes problemas da sociedade. Rio de Janeiro: Elsevier, 2010. 


\section{APÊNDICE}

\section{FEAUSP}

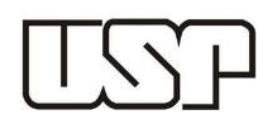

\section{ROTEIRO BÁSICO DE ENTREVISTAS - EMPRESAS}

A. Origem e Estágio da empresa:

a. Como a empresas começou (propósito)?

b. Quanto tempo de atuação tem a empresa?

c. Qual o estágio atual da empresa?

d. Neste período, como os indicadores foram utilizados, o que foi medido e como?

B. Momento Atual

a. A empresa faz gestão de indicadores? Quais? Quem é responsável? Qual o objetivo da utilização dos indicadores? Como estes indicadores são utilizados?

b. Quais os indicadores financeiros, econômicos e operacionais? Utilizam algum padrão?

c. Quais indicadores de geração de valor social são utilizados? Como são medidos?

d. Utilizam métricas padronizadas? Quais? Já utilizaram algumas?

e. Quais as principais dificuldades de mensuração dos indicadores de impacto social?

C. Ecossistema

a. Qual a relação sua com o ecossistema de negócios sociais?

b. Como o ecossistema influência a escolha e uso de indicadores?

c. O uso anterior de indicadores facilitou a interação ou a receber apoio das organizações de suporte ao ecossistema (aceleração, investimento, parceiros entre outros?)

d. Como o Ecossistema pode ajudar no uso de indicadores?

e. Os indicadores utilizados atualmente são aceitos pelo ecossistema? Quais as dificuldades? 


\section{APÊNDICE}

\section{FEAUSP}

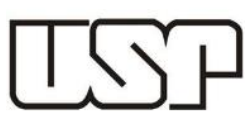

ROTEIRO BÁSICO DE ENTREVISTAS - ORGANIZAÇÕES DE SUPORTE

A. Uso de Indicadores:
a. Os uso de indicadores de geração de valor social são importantes?
b. Qual a importância dos indicadores para a gestão dos negócios sociais?
c. Qual padrão de métricas você pede para ser adotado?
d. Como a organização estimula o uso de indicadores e métricas?

B. Seleção de Empresas para Investimento/Aceleração
a. Como é feita a decisão da escolha das empresas que recebem investimento ou que são aceleradas?
b. É necessário que os indicadores já estejam sendo utilizados e/ou sistematizados?

C. Indicadores próprios

a. Quais métricas são utilizadas pela sua organização para gestão do valor social e econômico gerado?

b. Como estas métricas influenciam o processo de escolha e de acompanhamento do negócio suportado? 